\title{
METODOLOGIA PARA DIMENSIONAMENTO DE UM SISTEMA DE PULVERIZAÇÃO ACOPLÁVEL A PIVÔ CENTRAL
}

\author{
LUIS ARTUR ALVARENGA VILELA
}

Tese apresentada à Escola Superior de Agricultura "Luiz de Queiroz", Universidade de São Paulo, para obtenção do título de Doutor em Agronomia, Área de Concentração: Irrigação e Drenagem.

PIRACICABA

Estado de São Paulo - Brasil

Maio - 2002 


\section{METODOLOGIA PARA DIMENSIONAMENTO DE UM SISTEMA DE PULVERIZAÇÃO ACOPLÁVEL A PIVÔ CENTRAL}

\section{LUIS ARTUR ALVARENGA VILELA}

Engenheiro Agrícola

Orientador: Prof. Dr. TARLEI ARRIEL BOTREL Co-orientador: Prof. Dr. DURVAL DOURADO NETO

\footnotetext{
Tese apresentada à Escola Superior de Agricultura "Luiz de Queiroz", Universidade de São Paulo, para obtenção do título de Doutor em Agronomia, Área de Concentração: Irrigação e Drenagem.
}

PIRACICABA

Estado de São Paulo - Brasil

Maio - 2002 


\title{
FICHA CATALOGRÁFICA
}

\author{
Dados Internacionais de Catalogação na Publicação (CIP) \\ DIVISÃO DE BIBLIOTECA E DOCUMENTAÇÃO - ESALQ/USP

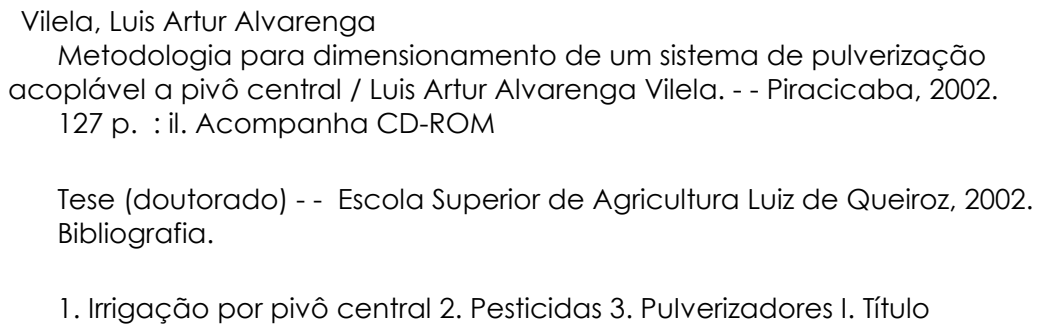

"Permitida a cópia total ou parcial deste documento, desde que citada a fonte - $O$ autor" 
À minha mãe, que me alfabetizou e me ensinou a escrever as primeiras palavras, ao meu pai, pelos oficios a mim instruídos,

\section{OFEREÇO}

À Angela e Larissa, que me completam,

DEDICO 


\section{AGRADECIMENTOS}

A Deus, pela minha existência.

À Escola Superior de Agricultura "Luiz de Queiroz" (ESAL/USP), notadamente ao Departamento de Engenharia Rural, pela oportunidade e facilidades oferecidas para a realização deste trabalho e de outros durante o curso.

À Universidade Federal de Lavras (UFLA), especialmente aos colegas do Departamento de Engenharia, que sempre me apoiaram.

A Tato Equipamentos Eletrônicos Ltda., pelas informações concedidas em todas as ocasiões.

Aos professores Tarlei Arriel Botrel e Durval Dourado Neto, pelos ensinamentos, orientação, amizade e incentivo em todas as atividades pertinentes ou não a este trabalho, mas que muito contribuíram para o meu crescimento profissional e pessoal.

Aos professores e funcionários do Departamento de Engenharia Rural da ESALQ/USP, pelo apoio e atenção.

Aos funcionários da Biblioteca da ESALQ/USP, em especial as senhoras Eliana Garcia e Sílvia Zinsly, pela revisão das referências bibliográficas e demais sugestões.

Aos grandes companheiros do curso de Pós-Graduação em Irrigação e Drenagem, pela amizade e respeito, em especial os engenheiros Axel García y García e Tamara Maria Gomes, pela revisão.

Ao meu padrinho, Paulo Armando e madrinha, Flávia, pelo constante incentivc

A todos os meus familiares, em especial Cássia e Simone, pela compreensão e carinho. 


\section{SUMÁRIO}

Página

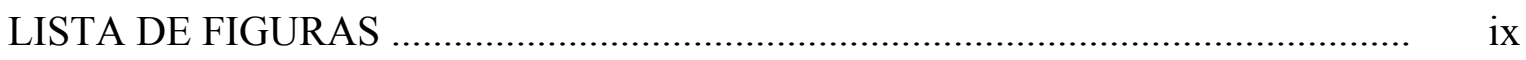

LISTA DE TABELAS …........................................................................ xii

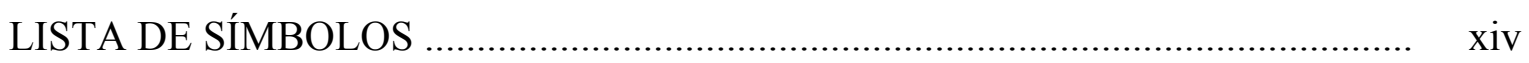

CURRICULUM VITAE .......................................................................... $\quad$ xvii

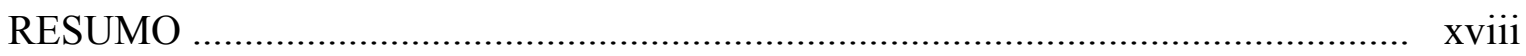

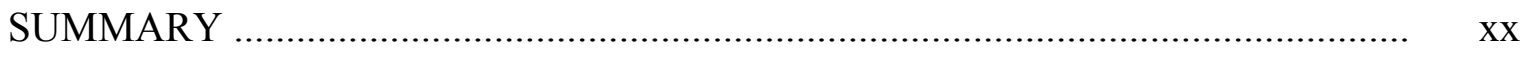

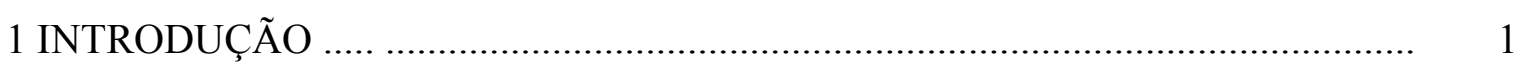

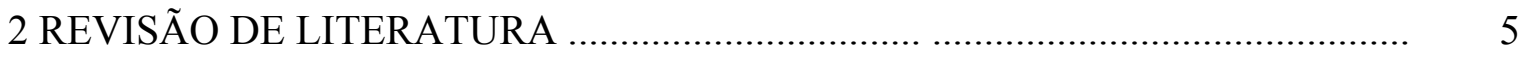

$2.1 \mathrm{O}$ sistema de irrigação por aspersão tipo pivô central ........................................ 5

2.2 Aplicação de produtos químicos e biológicos via água de irrigação ..................... 8

2.3 Equipamentos desenvolvidos para aplicação de defensivos agrícolas em pivôs

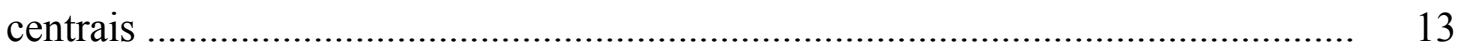

2.4 Parâmetros utilizados para caracterização do tamanho de gotas ........................... 18

2.5 Importância do tamanho de gotas na aplicação de defensivos agrícolas ................ 19

2.6 Técnicas para determinação do tamanho de gotas .............................................. 21

2.7 Avaliação da uniformidade de distribuição da pulverização ............................... 23

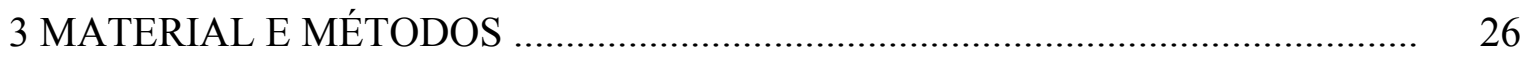

3.1 Localização e etapas do experimento ........................................................... 26

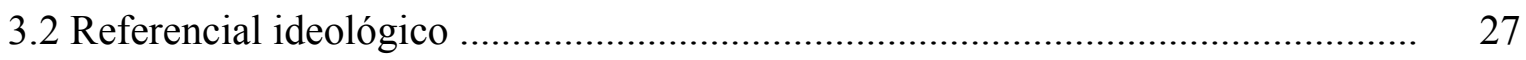

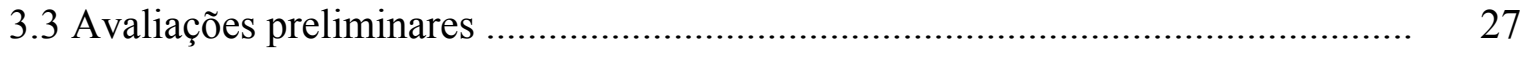

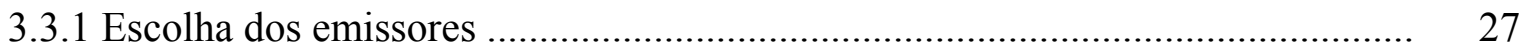


3.3.2 Avaliação da resposta hidráulica dos nebulizadores Fogger 7800 ..................... 29

3.3.3 Desenvolvimento e avaliação do protótipo da barra de pulverização ................. 30

3.4 Características do pivô central ........................................................................ 31

3.5 Componentes do sistema hidráulico da barra de pulverização .............................. 31

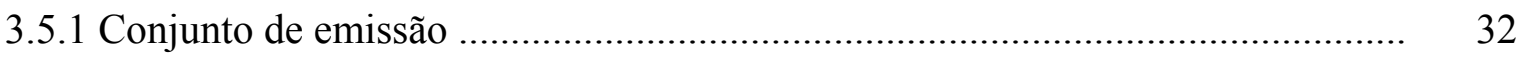

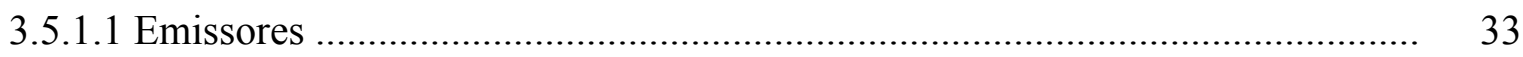

Perfil de distribuição da precipitação ......................................................................... 34

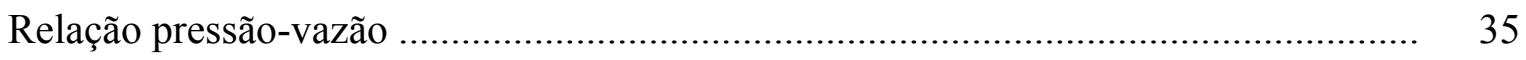

Coeficiente de variação de fabricação .................................................................. 37

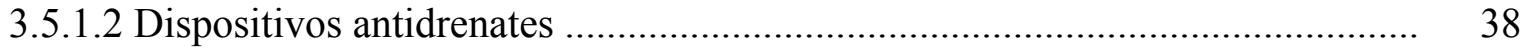

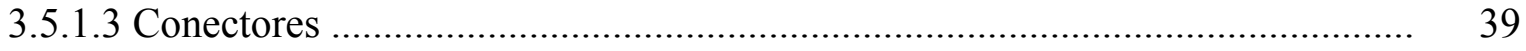

3.5.2 Barra de pulverização ................................................................................ 40

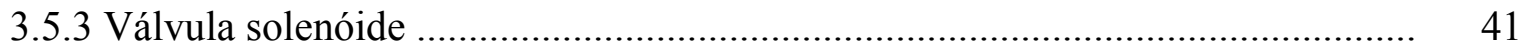

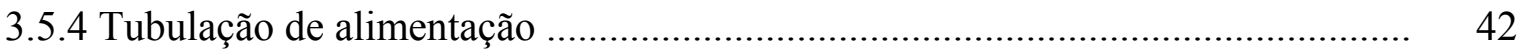

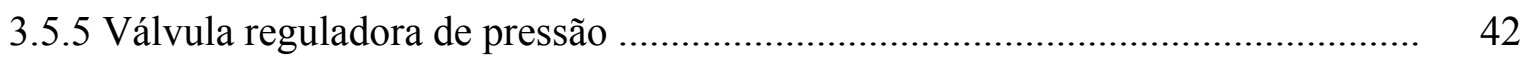

3.5.6 Tubulação de distribuição .................................................................................. 43

3.5.7 Sistema de pressurização e filtragem .............................................................. 43

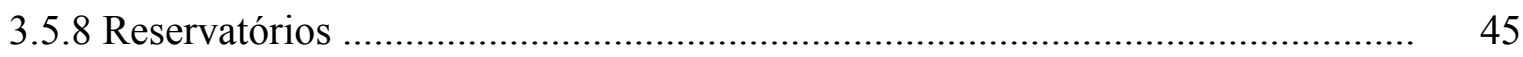

3.5.9 Descrição geral do funcionamento do sistema hidráulico ................................ 46

3.6 Componentes do sistema mecânico da barra de pulverização ............................... 46

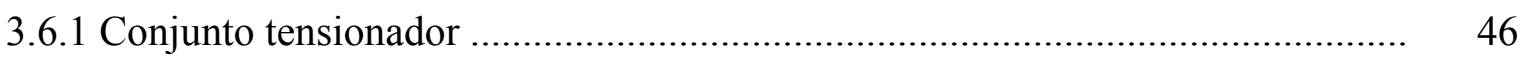

3.6.2 Conjunto de fixação .............................................................................. 48

3.6.3 Conjunto de controle da altura de aplicação ................................................... 49

3.6.4 Descrição geral do funcionamento do sistema mecânico ................................... 51

3.7 Componentes do sistema eletro-eletrônico da barra de pulverização .................... 52

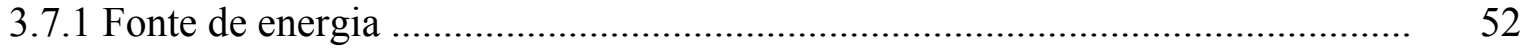

3.7.2 Circuito eletro-eletrônico e microcontrolador................................................ 53

3.8 Aspectos construtivos da barra de pulverização ............................................... 56

3.8.1 Variantes da velocidade de deslocamento ao longo do vão do pivô .................. 57

3.8.2 Comprimento e posicionamento das barras ................................................ 58 
3.8.3 Cálculo da largura máxima da faixa de deposição dos emissores ...................... 60

3.8.4 Determinação do posicionamento dos emissores na barra de pulverização ........ 61

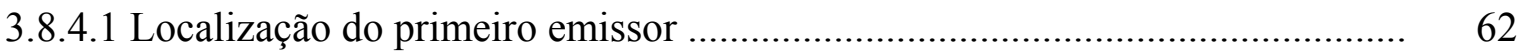

3.8.4.2 Cálculo do volume de pulverização do primeiro emissor ................................ 62

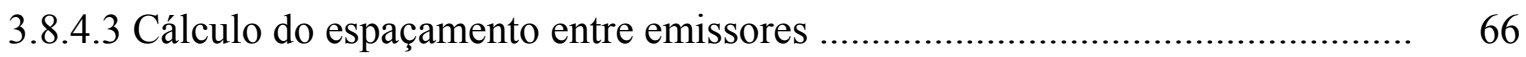

3.8.5 Estimativa da perda de carga na barra de pulverização ..................................... 68

3.9 Metodologia para avaliação do equipamento .................................................... 70

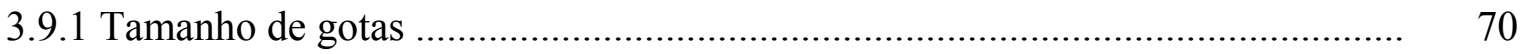

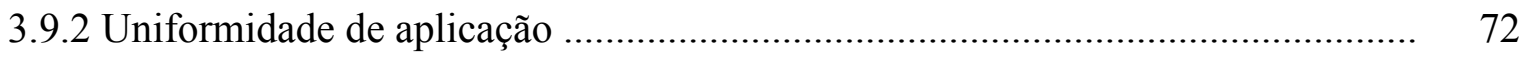

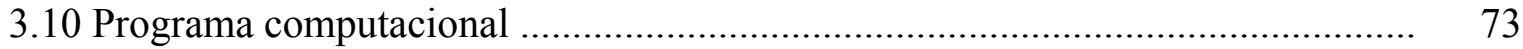

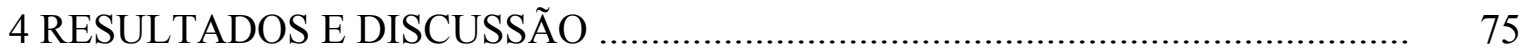

4.1 Resultados das avaliações preliminares ......................................................... 75

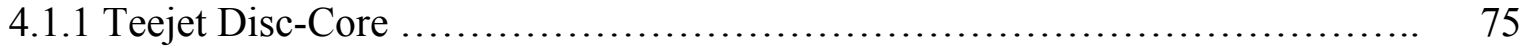

4.1.2 Fogger 7800 e protótipo da barra de pulverização .......................................... 75

4.2 Resultados da caracterização hidráulica dos emissores ...................................... 77

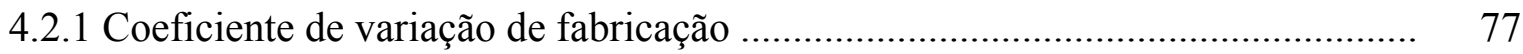

4.2.2 Equação característica da vazão em função da pressão .................................... 78

4.2.3 Perfil de distribuição da precipitação ............................................................. 80

4.3 Simulações das distribuições lineares ............................................................. 81

4.4 Largura máxima da faixa de deposição ............................................................ 83

4.5 Posicionamento e volume de pulverização do primeiro emissor ........................ 84

4.6 Resultados do dimensionamento da barra de pulverização ................................... 84

4.7. Avaliações do protótipo no laboratório ................................................................ 89

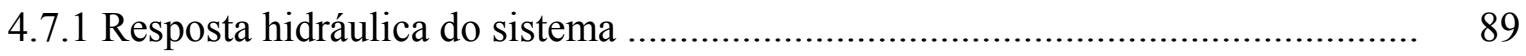

4.7.2 Variação de vazão de emissores semelhantes ao longo da barra ........................ 89

4.8 Avaliações do sistema de pulverização no campo ............................................. 92

4.8.1 Caracterização dos tamanhos de gotas ........................................................... 92

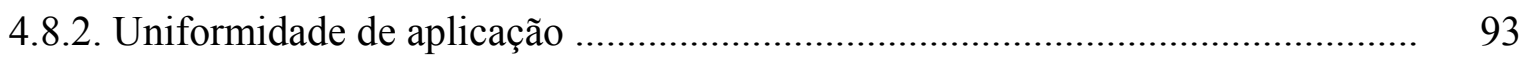

4.9 Dimensionamento empregando o programa computacional ............................... 98

4.10 Considerações finais ............................................................................ 103 
4.10.1 Consumo de energia ……...................................................................... 103

4.10.2 Custo do equipamento ............................................................................ 103

4.10.3 Risco de uso do equipamento ................................................................... 104

4.10.4 Injeção de produtos no sistema de pulverização .............................................. 105

4.10.5 Barra de pulverização da tubulação em balanço ................................................ 105

4.10.6 Inovações tecnológicas ............................................................................ 106

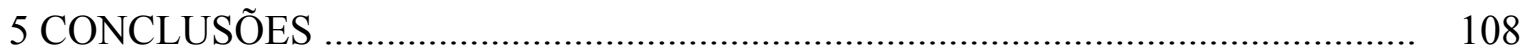

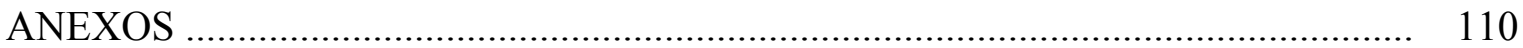

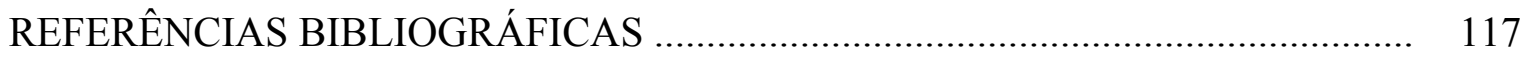

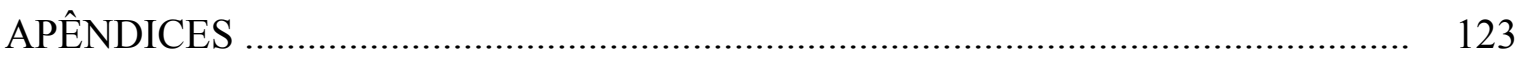




\section{LISTA DE FIGURAS}

Página

1 Representação esquemática do Índice de Eficiência de Aplicação (IEA) em função da calda utilizada ........................................................................... $\quad 10$

2 Esquema do circuito eletrônico do periférico utilizado para acionamento da válvula solenóide, por meio da porta paralela (PP) de um microcomputador, durante a realização dos ensaios preliminares ..................................................... 29

3 Aspecto geral do protótipo da barra de pulverização montado em laboratório .. 31

4 Componentes do conjunto de emissão: conjunto completo (a), conector (b), dispositivo antidrenante (c), emissor (d) ..................................................... 32

5 Esquema da disposição dos coletores para determinação do perfil de distribuição

6 Estrutura desenvolvida para avaliação das vazões dos emissores ........................ 37

7 Aspectos da montagem da barra de pulverização .................................................. 41

8 Vista do sistema de pressurização (a) e reservatório de captação (b) .................. 44

9 Conjunto tensionador (a) e detalhes de sua ligação ao conjunto de fixação (b) .. 47

10 Detalhes da ligação do conjunto de fixação à estrutura do pivô ......................... 48

11 Detalhes do conjunto de controle da altura de aplicação ..................................... 50

12 Detalhes da fixação das carretilhas ao triângulo que compõe a parte aérea do pivô (a) e das estruturas desenvolvidas para fixação dos cabos de aço secundários ao conjunto tensionador (b)

13 Vista da caixa elétrica adaptada para abrigar os componentes eletroeletrônicos 
14 Esquema do circuito eletrônico microcontrolado

15 Microcontrolador Basic Step (a) e aspecto final do circuito eletrônico desenvolvido (b)

16 Esquema ilustrativo das variantes de distribuições de velocidade (i,ii,iii) que podem ocorrer ao analisar um único vão de um pivô central

17 Esquema de posicionamento das barras de pulverização em um pivô central ...

18 Esquema ilustrativo das variáveis utilizadas no dimensionamento de uma barra de pulverização alimentada pela extremidade disposta entre os vãos I e K de um pivô central

19 Esquema de distribuição dos coletores sob a barra de pulverização

20 Variação do tamanho de gotas e respectivas frações de volumes para o Fogger 7800 , equipado com bocal vermelho, operando sob pressão de $300 \mathrm{kPa}$

21 Famílias de curvas pressão-vazão para o conjunto Fogger 7800/válvula reguladora de pressão, equipados com bocais azul, laranja, vermelho e preto ....

22 Valores observados e ajustados de intensidade de precipitação média (IP) ao longo do raio de alcance do Fogger 7800 equipado com válvula antigota e bocal azul (a), laranja (b), vermelho (c) e preto (d)

23 Posicionamento dos primeiros emissores em cada uma das barras de pulverização (I e II)

24 Intensidades de precipitações acumuladas (IPA) ao longo do vão, estimadas para cada uma das barras de pulverização (I e II)

25 Intensidades de precipitações acumuladas totais (IPAT) estimadas ao longo do vão, resultantes da associação das duas barras de pulverização

26 Vazão de emissores (E1, E2 e E3) equipados com válvulas antigotas e bocais pretos, posicionados no início, meio e fim da barra de pulverização, submetidos a um único pulso com duração de 3 minutos, sob pressão de $211 \mathrm{kPa}$

27 Vazão de emissores (E1, E2 e E3) equipados com válvulas antigotas e bocais pretos, posicionados no início, meio e fim da barra de pulverização, submetidos a 360 pulsos com duração de $0,5 \mathrm{~s}$ cada um, sob pressão de $211 \mathrm{kPa}$ 
28 Volumes de calda determinados para tempos ligado/desligado de 0,3/2,5s (a), $0,4 / 2,5$ s (b) e $0,5 / 2,5$ s (c) nas repetições I, II e III

29 Volumes de calda determinados para tempos ligados e desligados de $0,3 / 3,0 \mathrm{~s}$ (a), $0,4 / 3,0$ s (b) e $0,5 / 3,0$ s (c) nas repetições I, II e III

30 Volumes de calda determinados para tempos ligados e desligados de 0,3/3,5s (a), 0,4/3,5s (b) e 0,5/3,5s (c) nas repetições I, II e III

31 Tela principal do programa SPPC

32 Tela de entrada dos dados a serem empregados no dimensionamento da barra de pulverização pelo programa SPPC

33 Tela do programa SPC na qual são apresentados os resultados do dimensionamento da barra de pulverização 


\section{LISTA DE TABELAS}

Página

1 Caldas indicadas para a aplicação de alguns tipos de defensivos ........................ 11

2 Classes de tamanho de gotas e respectivas recomendações ................................. 19

3 Julgamento dos valores CV considerados em diferentes países e número de referências bibliográficas citadas .................................................................. 24

4 Codificação por cores, diâmetros e vazões nominais dos bocais Fogger 7800 ... 33

5 Recomendação para classificação de emissores quanto ao CVF ........................ 38

6 Características dos componentes do sistema de pressurização .............................. 44

7 Vazão média observada para os quatro modelos de bocais disponíveis para o emissor Fogger 7800, montado com dispositivos antidrenantes, e respectivos coeficientes de variação de fabricação

8 Coeficientes de ajuste da equação $(\mathrm{K})$ e expoentes característicos $(\mathrm{x})$ do Fogger 7800 equipado com quatro modelos de bocais e válvulas antigotas, operando sob pressões de 110 a $250 \mathrm{kPa}$, e respectivos coeficientes de determinação $\left(\mathrm{r}^{2}\right)$ das equações anamorfizadas .

9 Intensidades médias de precipitação ao longo do raio molhado pelo Fogger 7800 operando sob pressão de $211 \mathrm{kPa}$

10 Intensidades de precipitação $(\mathrm{mm} / \mathrm{h})$ acumuladas ao longo do raio de alcance do Fogger 7800 equipado com válvula antigota, para os quatro modelos de bocais disponíveis 
11 Largura máxima da faixa de deposição $\left(\mathrm{e}_{\operatorname{máx}}\right)$, coeficientes de variação dos somatórios das intensidades de precipitação acumuladas $(\mathrm{CV})$ e número de emissores que contribuíram para a sobreposição entre dois emissores consecutivos de mesmo modelo $(\mathrm{N})$.......................................................... 83

12 Resultados do dimensionamento da barra de pulverização .............................. 86

13 Valores médios de DMV e DMN observados nas tres linhas de avaliação (L1, L2 e L3) em diferentes posições ao longo do vão do pivô ................................ 92

14 Diferenças percentuais entre as lâminas estimadas e observadas e CV determinados para cada relação de tempos ligado/desligado avaliadas

15 Resumo dos resultados do dimensionamento da barra de pulverização realizado por meio da planilha eletrônica e do programa computacional SPPC . 102 


\section{LISTA DE SÍMBOLOS}

A Ampére (corrente elétrica)

$\mathrm{A}_{1} \quad$ Área coberta pelo primeiro emissor $\left(\mathrm{m}^{2}\right)$

C Calda (mistura de água e defensivo a ser aplicado) (L/ha)

CCI Calda crítica inferior (L/ha)

CCS Calda crítica superior (L/ha)

CDA Controlled drop application

$\mathrm{Ci}$ Calda ou volume de pulverização aplicado por unidade de área pelo i-ésimo emissor (L/ha)

cor $_{i} \quad$ Cor do bocal do i-ésimo emissor

CUC Coeficiente de uniformidade de Christiansen (\%)

CV Coeficiente de variação (\%)

cv Cavalo-vapor $(1 \mathrm{cv}=735,5 \mathrm{~W})$

CVF Coeficiente de variação de fabricação (\%)

D Diâmetro interno da tubulação (m)

$\mathrm{d}_{\mathrm{i}} \quad$ Distância entre o i-ésimo emissor e seu subseqüente $(\mathrm{m})$

DMN Diâmetro mediano numérico $(\mu \mathrm{m})$

DMV Diâmetro mediano volumétrico $(\mu \mathrm{m})$

DN Diâmetro nominal (mm)

dpi Pontos por polegada (dots per inch)

$D_{\mathrm{r}} \quad$ Distância entre o plano vertical que passa no centro geométrico das rodas e o último emissor (m)

$\mathrm{e}_{\mathrm{i}} \quad$ Largura da faixa de deposição do i-ésimo emissor (m) 


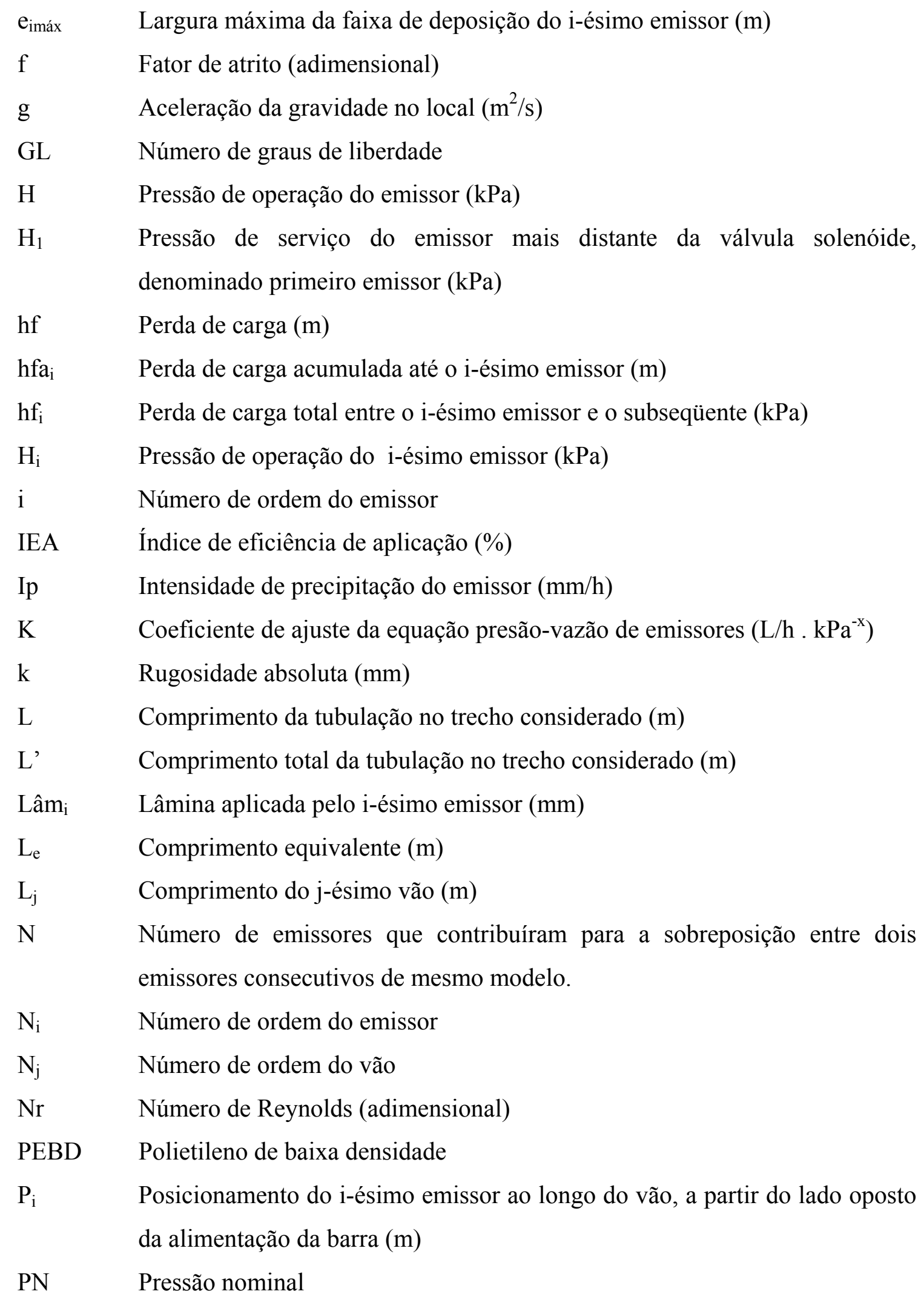


PP Porta paralela do microcomputador (conexão da impressora)

PVC Cloreto de polivinila

q Vazão do emissor $(\mathrm{L} / \mathrm{h})$

Q Vazão $\left(\mathrm{m}^{3} / \mathrm{s}\right)$

$\mathrm{qa}_{\mathrm{i}} \quad$ Vazão acumulada até o i-ésimo emissor $(\mathrm{L} / \mathrm{h})$

$\mathrm{q}_{\mathrm{i}} \quad$ Vazão do i-ésimo emissor $(\mathrm{L} / \mathrm{h})$

$\mathrm{q}_{\mathrm{m}} \quad$ Vazão média dos emissores contidos em uma amostra $(\mathrm{L} / \mathrm{h})$

$\mathrm{qn}_{\mathrm{i}} \quad$ Vazão do i-ésimo emissor operando sob pressão de $211 \mathrm{kPa}(\mathrm{L} / \mathrm{h})$

r Coeficiente de dispersão do espectro de gotas (adimensional)

$\mathrm{r}^{2} \quad$ Coeficiente de determinação

$\mathrm{r}^{2}$ crít $_{\mathrm{GL}, \alpha}$ Coeficiente de determinação crítico, para um determinado número de graus de liberdade (GL) e nível de significância $(\alpha)$

rpm Revoluções por minuto

SPPC Sistema de Pulverização para Pivô Central (programa computacional)

$\mathrm{s}_{\mathrm{q}} \quad$ Desvio padrão da vazão dos emissores contidos em uma amostra $(\mathrm{L} / \mathrm{h})$

$\mathrm{T}_{\mathrm{D}} \quad$ Tempo de fechamento da válvula solenóide (s)

$\mathrm{T}_{\mathrm{L}} \quad$ Tempo de abertura da válvula solenóide (s)

$\operatorname{Tr} \quad$ Tempo de revolução (h)

V Velocidade de escoamento do fluido $(\mathrm{m} / \mathrm{s})$

Vca Diferença de potencial sob corrente alternada (volt)

Vec Diferença de potencial sob corrente contínua (volt)

$\mathrm{V}_{\mathrm{j}} \quad$ Velocidade de deslocamento do sistema de propulsão da j-ésima torre $(\mathrm{m} / \mathrm{h})$

W Watt (potência)

$\mathrm{x} \quad$ Expoente característico do emissor (adimensional)

$\alpha \quad$ Nível de significância (\%)

$\Delta_{\mathrm{i}} \quad$ Diferença entre a calda aplicada pelo emissor que está sendo calculado e a calda a ser aplicada pelo sistema de pulverização (L/ha)

$\Omega \quad$ Ohm (resistência elétrica)

$\pi \quad$ Razão entre o perímetro e o diâmetro de uma circunferência (adimensional) 


\section{CURRICULUM VITAE}

Luís Artur Alvarenga Vilela é filho de Artur Bernardes Vilela e Anna Flora Alvarenga Vilela. Nasceu no dia 12 de agosto de 1966, em São Paulo-SP. Graduou-se Engenheiro Agrícola em julho de 1990, na Escola Superior de Agricultura de Lavras, atual Universidade Federal de Lavras (UFLA). De 1986 a 1995 desenvolveu atividades relacionadas à irrigação, tais como produção de mudas de café e condução de lavouras de milho, soja e feijão. Foi produtor de sementes certificadas de milho e básicas de feijão, em áreas irrigadas, junto à Fundação de Apoio ao Ensino, Pesquisa e Extensão FAEPE/UFLA. No ano de 1995 terminou o curso de Mestrado em Engenharia Agrícola, área de concentração Irrigação e Drenagem, na UFLA. Em março do mesmo ano foi contratado como professor substituto por essa instituição, tornando-se responsável pela disciplina Hidráulica Básica, até dezembro de 1996. No ano seguinte, lecionou na Central de Ensino e Desenvolvimento Agrário de Florestal (CEDAF/UFV), sendo responsabilizado, mediante aprovação em Concurso Público prestado junto à Universidade Federal de Viçosa (UFV), para ministrar aulas nas disciplinas de Desenho Técnico, Construções Rurais e Topografia. No final do mesmo ano foi contratado como professor assistente pela UFLA, onde trabalha atualmente lotado no Departamento de Engenharia, sendo responsável pelas disciplinas Irrigação (Graduação) e Irrigação por Aspersão (Pós-Graduação). No início de 2000 iniciou o curso de Doutorado em Agronomia, área de concentração Irrigação e Drenagem, na Escola Superior de Agricultura "Luiz de Queiroz" (ESALQ/USP). 


\title{
METODOLOGIA PARA DIMENSIONAMENTO DE UM SISTEMA DE PULVERIZAÇÃO ACOPLÁVEL A PIVÔ CENTRAL
}

\author{
Autor: LUIS ARTUR ALVARENGA VILELA \\ Orientador: Prof. Dr. TARLEI ARRIEL BOTREL \\ Co-Orientador: Prof. Dr. DURVAL DOURADO NETO
}

\section{RESUMO}

Com o objetivo de aplicar produtos químicos como herbicidas, fungicidas, inseticidas e fertilizantes, independentemente do alvo (solo ou planta), foram desenvolvidos uma metodologia para dimensionamento de um sistema de pulverização acoplável a pivô central, um protótipo do equipamento e um programa computacional. Durante a aplicação, a estrutura aérea do pivô desloca-se sem realizar irrigação, apenas transportando o equipamento de pulverização sobre a área. O sistema é composto de duas barras de pulverização instaladas em cada vão do pivô, de maneira a compensar as diferentes velocidades decorrentes de sua movimentação. O regime intermitente da pulverização, responsável pela redução da calda aplicada, é feito por meio de um circuito eletrônico microcontrolado, sincronizado ao acionamento dos motorredutores, o qual comanda uma válvula solenóide que controla a vazão da calda para a barra de pulverização. Os resultados demonstraram que: a metodologia desenvolvida permite dimensionar sistemas de pulverização acopláveis a pivô central com elevada uniformidade de aplicação; o sistema é capaz de aplicar um volume de pulverização 
mínimo de 246L/ha para os regimes de intermitência avaliados; os diâmetros mediano volumétrico e numérico médio do espectro de gotas foram de 126,30 e $98,25 \mu \mathrm{m}$, respectivamente, atendendo às recomendações técnicas para aplicação de defensivos agrícolas; o coeficiente de dispersão médio de 1,29 permite classificar o espectro de gotas como uniforme; as análises provenientes dos ensaios de uniformidade de distribuição para os tempos ligado/desligado da válvula solenóide de $0,4 / 2,5 \mathrm{~s}, 0,5 / 2,5 \mathrm{~s}$, $0,3 / 3,5 \mathrm{~s}$ e $0,4 / 3,5$ s resultaram em valores de coeficiente de variação inferiores a $15 \%$, podendo-se considerar aceitáveis para pulverizações por meio terrestre. Além disso, o dispositivo de controle de altura da barra de pulverização e o circuito eletrônico utilizado para gerar a intermitência de aplicação da barra mostraram-se adequados. O programa computacional possibilita fazer o dimensionamento hidráulico do sistema de pulverização para diferentes modelos de pivôs centrais, utilizando a metodologia de cálculo proposta. 


\title{
DIMENSIONING SPRAY SYSTEMS ATTACHED TO CENTER PIVOTS
}

\author{
Author: LUIS ARTUR ALVARENGA VILELA \\ Adviser: Prof. Dr. TARLEI ARRIEL BOTREL \\ Co-adviser: Prof. Dr. DURVAL DOURADO NETO
}

\section{SUMMARY}

Dimensioning methodology was developed to design and operate a spray system attached to a center pivot, for the purpose of applying chemical products as herbicides, fungicides, insecticides and fertilizers. Both a computer program and prototype equipment were developed. During the spray applications, the aerial structure of the center pivot system moved without irrigating, just transporting the spray system around the area. Two spray bars were installed in each pivot span, in order to compensate for different speeds. Intermittent sprays were used to reduce water application rates. Intermittent sprays were achieved by solenoid valves, which were controlled by microcontrolled electronic circuits synchronized with electric motor gears. The methodology developed allowed dimensioning an attached center pivot spray system with high application uniformity. The system could apply a minimum volume of $246 \mathrm{~L} / \mathrm{ha}$. The medium volumetric and numeric spectrum drop diameters were 126.30 and $98.25 \mu \mathrm{m}$, respectively. The medium dispersion coefficient was 1.29 , allowing us to classify the drop spectrum as uniform. On/off time sequences $0.4 / 2.5 \mathrm{~s}, 0.5 / 2.5 \mathrm{~s}, 0.3 / 3.5 \mathrm{~s}$ and $0.4 / 3.5 \mathrm{~s}$ resulted in coefficients of variation under $15 \%$, acceptable for ground applications. The controls designed for the spray bar height functioned as planned. The 
computer program developed in conjunction with the physical model allows the use of the methodology for other center pivot designs. 


\section{INTRODUÇÃO}

O cultivo em grandes áreas requer, na maioria das vezes, a utilização de tecnologias modernas, dentre elas o uso de defensivos agrícolas. As aplicações de tais produtos são feitas mediante pulverizações ou via água de irrigação, técnica conhecida por quimigação.

A utilização de aeronaves para aplicação de defensivos deve obedecer a uma série de fatores para que possa ser implementada. Esses fatores estão relacionados com a disponibilidade da aeronave, condicionantes de realização do vôo (chuva, neblina, pista de aterrissagem, abastecimento), necessidade de mão-de-obra auxiliar, distância do translado e a situação topográfica local. O custo da aplicação e a possibilidade de contaminação, tanto de auxiliares quanto do ambiente, também devem ser considerados.

A pulverização terrestre também nem sempre é possível por causa de condições meteorológicas, umidade do solo e porte da cultura, sobretudo. Nesse caso, também há de se considerar que o deslocamento do conjunto pulverizador pode provocar danos às plantas, o que é indesejável. A contaminação do operador é um outro fator preocupante nesse tipo de operação.

Na quimigação, o sistema de irrigação por pivô central aplica elevadas lâminas de água e produtos químicos, sendo que apenas uma pequena quantidade de ingrediente ativo permanece armazenada na parte aérea das plantas, reduzindo sensivelmente a eficiência de controle químico de produtos cujo alvo prioritariamente não é o solo, tais como herbicidas pós-emergentes, fungicidas de contato e alguns inseticidas. Por essa razão, esses tipos de formulações devem ser distribuídos mediante sistemas de pulverização capazes de aplicar caldas da ordem do volume máximo armazenável no 
alvo (300 a 600L/ha), o que corresponde a lâminas de irrigação cerca de uma centena de vezes menor do que as lâminas mínimas aplicadas pela maioria dos pivôs. A razão dessa diferença é que os equipamentos de pulverização deslocam-se com velocidades que podem chegar a 10 ou $300 \mathrm{~km} / \mathrm{h}$, no caso de pulverizadores terrestres ou aéreos, respectivamente, enquanto os pivôs centrais movimentam-se com velocidades que variam entre 0,12 e $0,30 \mathrm{~m} / \mathrm{h}$.

A redução da lâmina de irrigação visando à aplicação de produtos sobre a superfície vegetal, no caso do pivô central, poderia ser alcançada por duas maneiras distintas: diminuindo-se a vazão dos emissores, o que seria possível até um determinado limite, e/ou aumentando-se a velocidade de deslocamento do sistema de propulsão, o que poderia envolver problemas de ordem mecânica e econômica. Entretanto, essas técnicas tornar-se-íam antagônicas ao fornecimento de água às culturas, razão principal da instalação de um sistema de irrigação.

Os sistemas de pulverização acoplados a pivôs centrais desenvolvidos até o presente, de uma maneira geral, embora permitam taxas de aplicação próximas a $2.000 \mathrm{~L} / \mathrm{ha}$, relativamente inferiores às lâminas mínimas irrigadas por pivôs centrais, mas ainda significantemente superiores às recomendadas para alguns tipos de formulações químicas, apresentam outros problemas, como, por exemplo, a produção de gotas de maiores tamanhos, que impossibilitam a cobertura completa do alvo a ser pulverizado ou apresentam dificuldades para regulagem da altura da barra aplicadora.

As taxas de aplicação nesses equipamentos poderiam ser diminuídas empregando-se bocais de tamanho substancialmente reduzidos. Entretanto, existem limitações técnicas quanto ao emprego desses, que vão desde dificuldades relacionadas à própria fabricação até uma maior susceptibilidade ao entupimento, que poderia ocorrer simplesmente pela adição de produtos químicos à água para formação da calda a ser aplicada, e, dificilmente seria solucionada mediante filtragem.

Em razão da dificuldade de utilizar bocais de tamanho extremamente reduzidos associados a baixas velocidades de deslocamento, acredita-se que as aplicações mediante barras instaladas em pivôs centrais devam ocorrer de maneira intermitente e, mesmo assim, somente durante a movimentação dos sistemas de propulsão. 
Um outro problema que acompanha tais barras é a forma de movimentação de cada vão constituinte do pivô. Ao decompor seus movimentos, verifica-se que existem variantes de velocidade ao longo desses, decorrentes da operação ou não dos órgãos responsáveis pelo movimento, que não devem ser desconsideradas em situações nas quais se empregam emissores de pequeno alcance, concomitantemente à necessidade de se obter elevadas uniformidades de aplicação. Em razão do exposto, há a necessidade de que os vãos sejam equipados com duas barras de pulverização, alimentadas individualmente pelas suas extremidades junto às torres de sustentação, de maneira a compensar qualquer variação de velocidade procedente da forma de movimentação desses.

Acredita-se que as principais vantagens de um sistema de pulverização a ser instalado na estrutura aérea de um pivô central sejam: capacidade de aplicar qualquer formulação de inseticida, herbicida ou fungicida; redução do movimento de máquinas e conseqüentemente da compactação da área irrigada; economia e rapidez no tempo de aplicação; menor custo operacional; possibilidade de realização das aplicações a qualquer hora do dia ou da noite, independente do estádio fenológico da cultura, desde que respeitadas as condições de umidade relativa, temperatura e velocidade do vento; capacidade de aplicação em culturas de maior porte; menor disseminação de doenças nas lavouras quando comparados aos pulverizadores tratorizados e; menor risco de contaminação e poluição. Tais equipamentos também poderiam apresentar algumas limitações, como por exemplo: entupimento dos emissores; redução da vida útil dos componentes, em virtude do uso de formulações químicas e exposição em tempo integral às condições atmosféricas; e dificuldade em manter a barra de pulverização a uma certa distância do alvo em situações de relevo acidentado ou irregular.

Embora sejam necessários investimentos adicionais para a instalação de um sistema de pulverização no equipamento de irrigação, o que talvez fosse a maior limitação quanto ao emprego dessa tecnologia, as perdas de produção decorrentes da entrada de conjuntos pulverizadores na lavoura, associadas às outras vantagens mencionadas, poderiam viabilizar economicamente os investimentos realizados. 
Este trabalho propõe o desenvolvimento de uma metodologia para dimensionamento de sistemas de pulverização acopláveis a pivôs centrais. Com base nessa metodologia, e com o intuito de possibilitar o uso desse procedimento em qualquer modelo de pivô central, os objetivos secundários foram:

- construir e avaliar um protótipo pulverizador de defensivos agrícolas, capaz de aplicar quantidades de calda apropriadas aos alvos pretendidos (inclusive alvo folha), mediante gotas de tamanhos adequados, possibilitando a distribuição uniforme de produtos químicos ou biológicos (contato ou sistêmicos), com controle facilitado de altura da barra aplicadora, sincronizado ao acionamento dos motorredutores e de maneira intermitente, e - elaborar um programa computacional que permita dimensionar hidraulicamente sistemas de pulverização de acordo com a referida metodologia. 


\section{REVISÃO DE LITERATURA}

\subsection{O sistema de irrigação por aspersão tipo pivô central}

Coelho (1996) comenta que pivô central pertence ao grupo de sistemas mecanizados de aspersão e que foi idealizado pelo norte americano Frank Zybach na década de 40. Foi introduzido no Brasil no final dos anos 70, e, graças à grande versatilidade desse equipamento, fez sucesso entre os agricultores. Segundo o autor, o pivô central é atualmente o equipamento de irrigação mais comercializado e o que mais tem contribuído para o incremento da área irrigada no País.

No início eram máquinas simples acionadas por turbinas hidráulicas. A uniformidade de aplicação de água sobre a superfície do solo dependia do relevo e da extensão do pivô. Atualmente, a incorporação de diversos acessórios e dispositivos permitem a utilização desses equipamentos nas mais diversas situações.

Faria \& Vieira (1986) reportam que o pivô central é um sistema de irrigação por aspersão que opera em círculos, constituído de uma linha lateral com emissores, ancorada em uma das extremidades e suportada por torres dotadas de rodas equipadas com unidades propulsoras. Segundo os autores, a velocidade de rotação das torres em torno do ponto central (ponto pivô) é regulada por meio de um relé percentual situado no painel do equipamento, que comanda a velocidade de deslocamento da última torre.

Pereira (2001) informa que o deslocamento de toda linha lateral do pivô central no campo é comandado pelo andamento da torre mais externa. Segundo o autor, supondo-se inicialmente que todas as torres encontrem-se alinhadas e apenas a última se movimente, o acionamento do motorredutor da torre subseqüente processa-se quando o 
vão em movimento deflete-se em relação aos demais. Continuando o processo entre todos os vãos adjacentes, promove-se a movimentação de toda a linha de irrigação pelo funcionamento intermitente dos motorredutores das torres. O autor comenta ainda que embora a velocidade angular de deslocamento do pivô central seja constante, a velocidade média de deslocamento de cada torre deve ser progressivamente maior a partir do ponto pivô, de maneira a induzir o movimento circular do equipamento na área. Como a área irrigada é progressivamente maior, aumenta-se também a vazão dos emissores ao longo da linha lateral do equipamento, objetivando que toda área irrigada receba a mesma lâmina de água de maneira uniforme. Dessa forma, têm-se elevadas intensidades de aplicação de água na extremidade final do pivô e menores intensidades de aplicação nas proximidades do centro do equipamento.

Bernardo (1989) comenta que o comprimento do pivô pode variar de 200 a $800 \mathrm{~m}$, irrigando áreas de aproximadamente 12 a 200ha, respectivamente, com a distância entre as torres variando de 40 a $76 \mathrm{~m}$.

O pivô central é o sistema de irrigação por aspersão mais automatizado que existe no mercado. Essa automação pode variar desde simples acessórios a componentes que permitem colocá-lo em funcionamento a distância, por meio de ondas de rádio ou telefone celular. Existem também pivôs que são totalmente controlados por estações computadorizadas capazes de coletar dados (umidade do solo, evapotranspiração, pluviometria, p.e.), analisá-los e avaliar o momento ideal e a exata quantidade de água que deverá ser aplicada para suprir a demanda da cultura (Vilela, 1999).

Comparando a irrigação por pivô central com outros sistemas de irrigação por aspersão, constata-se que o primeiro apresenta diversas vantagens, tais como: $i$ ) reduzida necessidade de mão-de-obra para a realização da irrigação; ii) capacidade de obter maiores produtividades em razão dos menores turnos de rega adotados, mantendo o conteúdo de água no solo próximo à capacidade de campo; iii) elevada uniformidade de distribuição de água quando os emissores e válvulas reguladoras de pressão forem corretamente dimensionados, instalados e encontrarem-se em perfeitas condições de operação; iv) facilidade de automação; v) dependendo das condições pedológicas e topográficas, um único equipamento é capaz de irrigar áreas de até 200ha, e vi) o custo 
do equipamento por unidade de área irrigada decresce com o aumento dessa (Keller, 1984; Cuenca, 1989; Keller \& Bliesner, 1990).

Os mesmos autores citam as principais limitações do sistema de irrigação por pivô central: i) pela particularidade de irrigarem áreas circulares, ocasionam perdas de áreas cultiváveis da ordem de $20 \%$; ii) a intensidade de aplicação de água na extremidade final do equipamento é bastante elevada, podendo chegar a $100 \mathrm{~mm} / \mathrm{h}$, o que limita sua utilização em solos com menor capacidade de infiltração de água; iii) exige que a área seja totalmente livre de obstáculos, muito embora já existam alternativas para contornar algumas situações, e $i v$ ) a dificuldade de assistência técnica especializada em algumas regiões, principalmente para os equipamentos mais modernos e sofisticados.

Segundo Bernardo (1989), no Brasil, até junho de 1988, só o fabricante de pivôs Asbrasil S.A. já havia instalado 1.015 equipamentos desse tipo, irrigando uma área de 82.167ha, perfazendo uma área média de aproximadamente 81ha por cada unidade instalada.

Favetta (1998), em seus estudos, levantou informações de 89 pivôs centrais localizados em oito Estados brasileiros, verificando que a área média irrigada por cada equipamento é de 63,84ha.

Embora não existam dados atualizados sobre o número de pivôs instalados em nosso País, Christofidis (2001) estima que a área irrigada do Brasil, até o ano de 1999, era de 2.950.230ha. Desse total, o autor contabilizou 561.843ha irrigados por pivô central, o que corresponde a $19,04 \%$ da área total irrigada.

Considerando os tamanhos médios de áreas irrigadas por pivô central relatados por Bernardo (1989) e Favetta (1998) e a área irrigada por pivô central no Brasil informada por Christofidis (2001), pode-se estimar que o número de pivôs em operação no Brasil deve estar compreendido entre 6.936 e 8.800 unidades. 


\subsection{Aplicação de produtos químicos e biológicos via água de irrigação}

A aplicação de produtos químicos e biológicos na lavoura via água de irrigação é uma técnica utilizada nos Estados Unidos da América desde a década de 50 (Stone et al., 1994).

Threadgill (1985) comenta que o sistema de irrigação por pivô central tornou-se uma efetiva ferramenta para a aplicação de produtos químicos nas lavouras irrigadas, enquanto Chalfant \& Young (1982) relatam que, com o advento da irrigação por pivô central, houve um acréscimo na quantidade de produtos químicos que podem ser aplicados às culturas via água de irrigação.

De acordo com as informações de Johson et al. (1986), existem diversos tipos de produtos que podem ser aplicados simultaneamente à irrigação, destacando-se fertilizantes, herbicidas, inseticidas, fungicidas, nematecidas, reguladores de crescimento e produtos biológicos.

Diversas são as vantagens do uso dessa técnica, destacando-se:“i) alguns produtos podem ser mais eficazes quando aplicados via água de irrigação, embora nem todos apresentem resultados satisfatórios, devendo ser preferencialmente aplicados pelos métodos convencionais (trator ou avião); ii) redução do custo de aplicação; iii) potencial de redução nas doses dos produtos químicos; $i v$ ) melhor uniformidade de distribuição do produto na área; v) maior segurança para o aplicador; vi) redução da compactação do solo e dos danos mecânicos à cultura; vii) possibilidade de aplicação do produto na época desejada; viii) incorporação e ativação do produto pela água de irrigação, e $i x$ ) redução na deriva, principalmente quando comparada a aplicações aéreas. As principais desvantagens do uso da quimigação são: i) possibilidade de menor eficiência de fungicidas no caso de uma epidemia; ii) indisponibilidade de formulações apropriadas e de defensivos registrados para aplicação via água de irrigação; iii) possibilidade de contaminação do ambiente; iv) necessidade de pivô central de alta velocidade para possibilitar a aplicação de pequenas lâminas de água; v) maior tempo de aplicação quando comparado às aplicações aéreas, e vi) possibilidade de aumento do processo 
corrosivo das partes metálicas do equipamento em contato com o produto" (Vieira, 1994, p.15).

Summer et al. (1997) reportam que a quimigação é utilizada com sucesso nos sistemas de irrigação por pivô central. Entretanto, em muitas circunstâncias, esses equipamentos aplicam elevadas lâminas de água, as quais provocam diminuição dos resíduos de produtos aplicados nas folhas. Segundo os autores, a redução da quantidade de água aplicada pelos pivôs centrais poderia ser alcançada mediante o uso de emissores de baixa vazão e/ou modificações nos sistemas de transmissão, com o objetivo de aumentar a velocidade de deslocamento do equipamento. Os autores também relatam que algumas formulações não são apropriadas para aplicação via água de irrigação, mesmo quando são utilizadas lâminas inferiores a 2,5mm.

Chalfant \& Young (1982) comentam que as lâminas usuais de irrigação em pivôs centrais variam de 5 a $25 \mathrm{~mm}$, podendo ser inferiores a 2,5 $\mathrm{mm}$ nos equipamentos que possuem sistemas de transmissão capazes de proporcionar altas velocidades de deslocamento.

Diversos autores relatam sobre a dificuldade de aplicação de produtos químicos quando esses devem permanecer na parte aérea da cultura (Vieira, 1994; Silveira et al., 1987; Summer et al., 1997).

De acordo com Fancelli \& Dourado Neto (2000), no caso específico das técnicas de insetigação, fungigação e herbigação, torna-se fundamental esclarecer que a eficiência de controle químico, por intermédio de inseticida, fungicida e herbicida, é diretamente proporcional à quantidade de ingrediente ativo que atinge o alvo. Segundo os autores, dentre os diferentes fatores que afetam a quantidade de ingrediente ativo que atinge o alvo, o volume de água por unidade de área é o principal fator no caso da quimigação foliar. Na Figura 1, adaptada dos autores, verifica-se a variação da quantidade de ingrediente ativo que atinge o alvo folha em função da calda (mistura de água e defensivo a ser aplicado, em L/ha) utilizada. Também é possível observar que até o valor de calda crítica inferior (CCI), que define a zona 1, há um acréscimo linear da quantidade de ingrediente ativo que atinge o alvo folha por causa da aplicação do produto puro. No caso de formulações líquidas, a calda é a própria dose do produto. No 
caso de formulações sólidas, deve-se levar em consideração a solubilidade do produto, até que a quantidade de ingrediente ativo que atinge o alvo seja igual à dose recomendada para o controle químico, o que corresponde a um índice de eficiência de aplicação de 100\%. Entre os valores de CCI e calda crítica superior (CCS), que corresponde à zona 2, assume-se que todo ingrediente ativo aplicado fica retido na superfície da cultura. Acima do valor da CCS (zonas 3), existe a limitação de área foliar por unidade de área de solo explorado pela cultura, arquitetura da parte aérea da planta, natureza hidrofóbica da folha (presença de cerosidade, principalmente) que provocam a lavagem do produto em virtude do elevado volume de água por unidade de área, associado ao tamanho de gota.

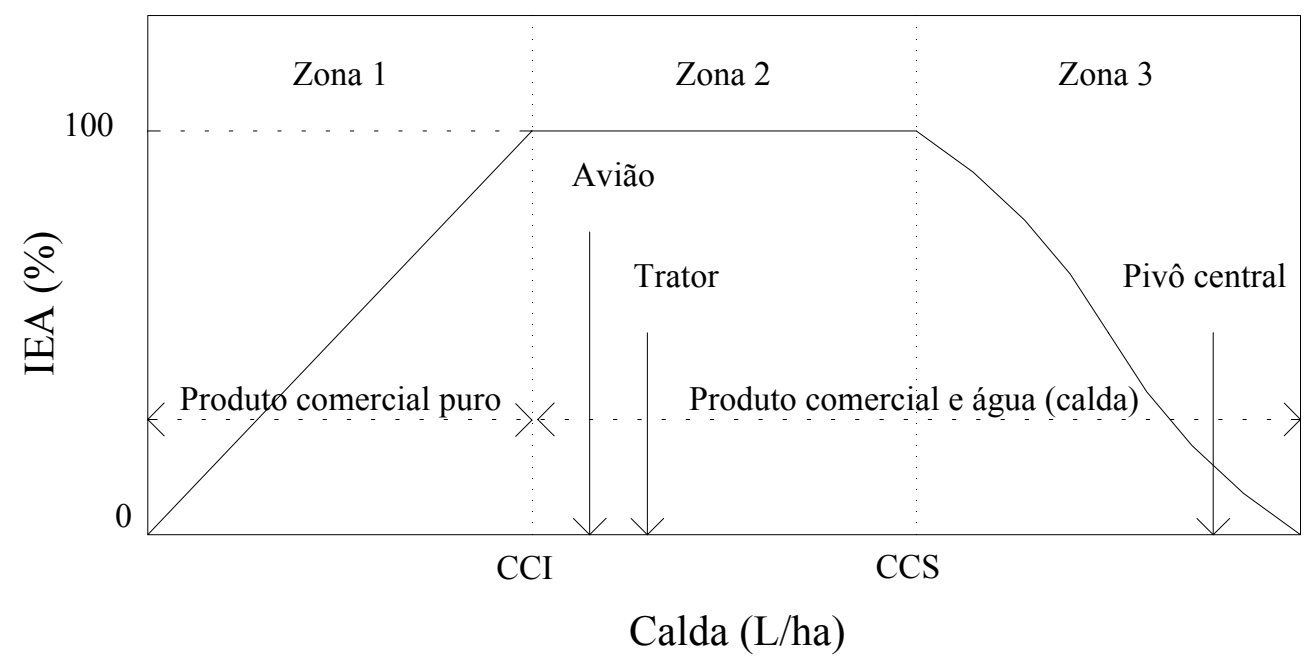

Figura 1 - Representação esquemática do Índice de Eficiência de Aplicação (IEA) em função da calda utilizada.

Fonte: adaptado de Fancelli \& Dourado Neto (2000).

Os mesmos autores também informam que as técnicas de irrigação e quimigação possuem critérios de projeto diferentes, pois apresentam lâminas desejáveis antagônicas. A ordem de grandeza da evapotranspiração máxima depende da cultura e dos atributos climáticos. Como comparação da lâmina aplicada na quimigação com a 
empregada na pulverização, os autores citam que um pivô central capaz de irrigar uma lâmina mínima de 40mm, que corresponde um volume de 40.000L/ha, aplicaria uma calda cerca de uma centena de vezes maior do que as recomendadas para a maioria dos defensivos agrícolas.

Basanta et al. (2000), estudando a interceptação de água pela parte aérea de plantas de milho, verificaram que o volume retido pela folhagem da cultura é proporcional ao índice de área foliar e à natureza da superfície das folhas. Segundo os autores, lavouras de milho com índices de área foliar 4 são capazes de reter no máximo $2.000 \mathrm{~L} /$ ha sobre a folhagem. Esse volume, quando comparado aos aplicados na irrigação, proporciona a retenção de cerca de $5 \%$ da quantidade de produto químico sobre a superfície das plantas, reduzindo a eficiência de controle quando o alvo é a folha.

De maneira geral, os melhores resultados na aplicação de defensivos têm sido observados com as caldas especificadas na Tabela 1. Com a utilização de caldas próximas a 300L/ha, o que corresponde a uma lâmina de $0,03 \mathrm{~mm}$, seria perfeitamente possível atender tanto à aplicação de herbicidas, quanto de inseticidas e fungicidas.

Tabela 1. Caldas indicadas para a aplicação de alguns tipos de defensivos.

\begin{tabular}{cc}
\hline Tipo de defensivo & Calda (L/ha) \\
\hline Herbicidas & 200 a 400 \\
Inseticidas & 100 a 300 \\
Fungicidas & 300 a 500 \\
\hline
\end{tabular}

Fonte: Máquinas Agrícolas Jacto S/A (s.d.).

Young et al. (1981) verificaram que a solubilidade é uma importante propriedade do inseticida para que ele possa ser aplicado via água de irrigação. Segundo os autores, inseticidas solúveis em água devem ser evitados na insetigação para o controle de pragas que se alimentam da cultura, pois, normalmente são lavados das folhas e vão para o solo.

Segundo Chalfant \& Young (1982), para reduzir a lavagem de inseticidas das folhas, esses podem ser formulados com ausência de emulsificantes ou também ser 
aplicados na forma de formulações insolúveis em água, ou ainda adicionar óleos minerais ou vegetais com o objetivo de reduzir a lavagem do inseticida da planta.

Silveira et al. (1987) comentam que inseticidas que contêm óleo na formulação (inseticidas oleosos ou dispersos em óleo) são transportados pela água de irrigação como discretas gotas e se aderem às folhas das plantas ou insetos após o contato.

Johson et al. (1986) relatam que diversos tipos de herbicidas têm sido aplicados por intermédio da água de irrigação, incluindo herbicidas pré-emergentes e pósemergentes. Reportam também que herbicidas pós-emergentes não apresentam bons resultados no controle de plantas daninhas. De acordo com as informações dos autores, os herbicidas pós-emergentes são normalmente aplicados mediante pulverização aérea ou terrestre, sob caldas que variam de 9 a 187L/ha. Comentam também que caldas superiores a 900L/ha podem causar o escorrimento do herbicida nas folhas, reduzindo a eficiência do controle.

A aplicação de fungicidas via água de irrigação tem sido realizada há mais de 25 anos em alguns países. Um grande número de resultados indica que produtos sistêmicos possuem maior efeito sobre a doença a ser controlada, quando comparados aos produtos de contato.

Almeida Pinto (1994) comenta que os fungicidas sistêmicos de translocação acropetal e de translocação acropetal e basipetal apresentam melhores resultados do que os fungicidas de contato, pois parte do produto que alcança o solo pode ser absorvido pelas raízes, translocando-se para parte aérea. $\mathrm{O}$ autor recomenda que para fungicidas que visam ao controle de fungos no solo, deve-se usar lâminas de 10 a $25 \mathrm{~mm}$ para promover a incorporação desses no perfil do solo. Entretanto, segundo o autor, fungicidas que visam a controlar doenças da parte aérea das plantas devem ser aplicados com lâminas de água de 3 a 6mm. No caso de aplicações em pivô central, o equipamento deve se deslocar com a máxima velocidade, de maneira a aplicar a menor lâmina de água, na tentativa de que pelo menos parte do produto permaneça retida na folhagem.

Johnson et al. (1986) comentam que a aplicação de alguns tipos de fungicidas via água de irrigação pode ser antieconômica, além de contribuir para uma maior contaminação do ambiente. Segundo os autores, para que seja obtido o mesmo resultado 
da pulverização convencional, é necessário, em determinadas circunstâncias, que a dosagem de alguns produtos seja cerca de 3 a 6 vezes superior para obtenção de resultados equivalentes.

Pelo que se observa, o suprimento de água às culturas, por meio de irrigação, confronta-se com a técnica de aplicação de produtos químicos ou biológicos, quando realizadas conjuntamente, em situações nas quais o alvo é a parte aérea das plantas. Isso se deve ao fato de que, na grande maioria das vezes, as lâminas mínimas de irrigação aplicadas pelos sistemas de irrigação do tipo pivô central são maiores do que os volumes de calda que tornam eficientes as aplicações de diversos produtos, principalmente alguns tipos de inseticidas, herbicidas pós-emergentes e fungicidas de contato.

\subsection{Equipamentos desenvolvidos para aplicação de defensivos agrícolas em pivôs centrais}

De acordo com informações de Sumner et al. (1997), o grande volume de água aplicado durante a irrigação pode promover menor deposição do produto químico sobre o alvo, reduzindo a eficiência de controle. Além disso, nas condições em que o solo estiver suficientemente úmido e houver a necessidade de aplicação de um determinado produto químico, haveria desperdício de água e energia.

Vieira (1994) comenta que as maiores dificuldades para aplicação de produtos químicos, via água de irrigação, com boa eficiência de utilização do produto, resumemse atualmente em alguns tipos de fungicidas e inseticidas, além dos herbicidas pósemergentes.

Larsen (1980) relata que o consultor em irrigação norte-americano Peter Garvey, objetivando aproveitar a estrutura de um pivô central (parte aérea) para aplicação de inseticidas e herbicidas, idealizou um sistema em que a calda não é transportada pela água de irrigação. Nesse sistema, a solução química é recalcada por meio de uma bomba centrífuga a partir de reservatórios situados no centro do pivô. Após o bombeamento, a mistura do produto é conduzida por meio de uma tubulação secundária, paralela à linha que normalmente conduz água durante a irrigação. Em cada torre do pivô existe uma 
válvula solenóide, que é acionada simultaneamente ao movimento de cada torre, permitido a passagem da solução para uma tubulação plástica, individualizada para cada torre, onde existem bocais responsáveis pela distribuição da solução. Durante a aplicação da solução, a parte aérea do pivô central funciona apenas como um veículo que transporta a barra de pulverização sobre a superfície cultivada, não realizando irrigação. Segundo o autor, o volume de pulverização aplicado por esse tipo de equipamento é de $1.600 \mathrm{~L} / \mathrm{ha}$. Tal equipamento encontra-se coberto pela patente norteamericana $\mathrm{n}$ ㅇ US 4.277.026 (Garvey, 1981).

Baseado no sistema idealizado por Garvey (1981), Sumner et al. (1997) propuseram um sistema para aplicação de produtos químicos de menor custo, denominado PASS (Pivot Attached Sprayer System). É composto de linha de pulverização, válvulas solenóides, reguladores de pressão, tubulação de distribuição, tubos de descida, válvulas antigotas e microaspersores espaçados de 3,0 a 3,6m. Os autores concluíram que, para taxas de aplicação de 1.900L/ha, os microaspersores utilizados para a distribuição da solução podem ser igualmente espaçados nas torres que possuem a mesma velocidade de deslocamento sem que ocorram prejuízos para a uniformidade de distribuição. Em razão dos pequenos volumes por unidade de área aplicados pelo sistema $(0,19 \mathrm{~mm}$ ou $1.900 \mathrm{~L} / \mathrm{ha})$, a uniformidade de distribuição de água não pôde ser avaliada por intermédio de coletores, de maneira semelhante às técnicas empregadas para avaliação de uniformidade de água no campo em sistemas de irrigação por aspersão. Assim, empregou-se o Método WRK, desenvolvido para avaliações de pulverizações realizadas por aeronaves, que dispõe de um periférico que se comunica com computador informando os resultados de uma análise fluorométrica. Essa análise é feita com base em um cordão de algodão previamente disposto perpendicularmente ao deslocamento do sistema pulverizador, o qual é exposto a um marcador fluorescente. Os resultados foram aplicados em um modelo de simulação computacional desenvolvido para avaliar a distribuição de água em pivôs centrais, obtendo-se Coeficientes de Uniformidade de Christiansen (CUC) que variaram entre 87 e 95\%.

Informações contidas em Pivot Barra - Indústria e Comércio Ltda (s.d.) constam que a empresa produziu no Brasil uma barra pulverizadora para instalação em pivôs 
centrais capaz de aplicar produtos tais como inseticidas, fungicidas, herbicidas e adubações líquidas. O sistema consiste em uma barra de alumínio onde são montados bicos de pulverização. Essa barra possui o mesmo comprimento de cada torre do pivô, sendo conectadas ao sistema de automação por meio de mangueiras flexíveis. O sistema de automação é composto de válvula solenóide, válvula reguladora de pressão, de retenção e filtros de linha. Quando ocorre o acionamento de um motorredutor de um determinado lance de torre, a válvula solenóide permite que o fluxo de solução seja derivado de uma tubulação de distribuição para a barra pulverizadora desse mesmo lance. A altura da barra pulverizadora pode ser ajustada por meio de um sistema composto de cabos-de-aço, roldanas e catracas. Os bicos pulverizadores são dimensionados para atender à vazão necessária em cada posição ao longo da barra distribuidora e são equipados com válvulas antigotas. Um conjunto de bombeamento instalado na torre central é responsável pela pressurização do sistema e também por um agitador hidráulico que mantém a homogeneidade da calda. Um pequeno conjunto motobomba auxiliar é instalado no ponto de captação de água do sistema de irrigação, fazendo uso da mesma adutora do sistema de irrigação para alimentar os tanques de mistura no centro do pivô. Segundo o fabricante, para velocidades de deslocamento de 120,6 e $362,4 \mathrm{~m} / \mathrm{h}$, o sistema aplica 1.526 e $508 \mathrm{~L} / \mathrm{ha}$, respectivamente, quando os bicos estão espaçados de $75 \mathrm{~cm}$ e operando sob pressão de $100 \mathrm{kPa}$.

Dourado Neto \& Fancelli (1999) propuseram um sistema para aplicação de produtos químicos em pivô central, que tem por finalidade adequar o volume de calda à quantidade de ingrediente ativo retido no alvo. Esse sistema, denominado Notliada, dispõe de um sistema de automação em que a aplicação da calda é interrompida por intermédio de válvulas solenóides. Dessa forma, a aplicação em uma determinada torre do pivô ocorre somente quando o motorredutor da torre em questão entra em funcionamento.

No sistema Notliada empregaram-se pontas de pulverização de jato plano de grande ângulo, modelo Turbo Teejet, fabricados pela Spray Systems Co.. As pontas 
foram montadas em corpos plásticos e acompanhadas por elementos filtrantes, de acordo com Dourado Neto. ${ }^{1}$

Pereira (2001) desenvolveu um protótipo aplicador de produtos químicos para instalação em pivôs centrais, idealizado com base no sistema Notliada. Nesse aplicador, a água é conduzida pela mesma adutora até o ponto pivô. A energia hidráulica requerida para esse transporte e pressurização do sistema é fornecida por uma bomba, de menor potência que a do sistema de irrigação, montada no mesmo ponto de captação. No centro do pivô central instalou-se um registro na adutora, cuja função é interromper o fluxo de água para o equipamento de irrigação, possibilitando a alimentação do cabeçal de controle. $\mathrm{O}$ cabeçal tem por finalidade realizar uma nova filtragem e injetar produtos químicos, formando a calda a ser aplicada. A injeção é feita por meio de uma bomba dosadora de alta precisão. A partir do cabeçal, a solução é transportada por tubulações plásticas, presas por abraçadeiras à tubulação principal da parte aérea do pivô, até a torre de sustentação do vão em questão. Nesse ponto foram instaladas válvulas solenóides que permitem controlar o fluxo de calda para o conjunto de emissão. O conjunto de emissão é composto por válvula reguladora de pressão, tubo de polietileno, microaspersores e válvulas antigota. No cálculo da vazão de cada emissor, considerou-se a posição desse em relação ao ponto central do pivô, objetivando-se manter constância na lâmina aplicada em toda a extensão do equipamento. O protótipo dispõe de um sistema que permite a regulagem da altura de aplicação, mediante diferentes posicionamentos de abraçadeiras que são aparafusadas em cantoneiras metálicas. A lâmina média aplicada pelo equipamento desenvolvido e o coeficiente de uniformidade de Christiansen (CUC), determinados no ensaio de uniformidade de distribuição de água, foram de $0,243 \mathrm{~mm}$ $(2.430 \mathrm{~L} / \mathrm{ha})$ e $82 \%$, respectivamente.

O elevado volume de pulverização, quando comparado às caldas recomendadas pelos fabricantes de defensivos, associado à dificuldade de regulagem da altura de aplicação e as gotas de maior tamanho produzidas pelos microaspersores, que não

\footnotetext{
${ }^{1}$ DOURADO NETO, D. (Escola Superior de Agricultura "Luiz de Queiroz". Departamento de Produção Vegetal. Piracicaba - SP). Comunicação pessoal, 2000.
} 
proporcionam uma cobertura adequada da superfície vegetal, são vistos como os principais inconvenientes desse equipamento.

A empresa norte americana Valmont Industries Inc. desenvolveu um sistema de pulverização para ser incorporado, como acessório, nos pivôs centrais que fabrica. Esse equipamento, denominado Accu-Pulse, realiza a pulverização de maneira intermitente e pulsativa, sincronizada ao funcionamento do sistema de deslocamento do pivô. O fabricante informa que as gotas grandes produzidas pelo aplicador penetram mais eficientemente nas partes baixas das plantas, além de estarem menos sujeitas ao arraste por ação de ventos. Reforça ainda que o consumo energético do equipamento representa uma pequena fração quando comparados a outros sistemas de pulverização, sejam eles terrestres ou aéreos (Valley Magazine, 2001). Buchleiter et al. (2001) comentam que o Accu-Pulse é capaz de aplicar volumes de pulverização reduzidos, da ordem de 230L/ha.

Embora o Accu-Pulse realize aplicações com baixos volumes de calda, esse sistema foi desenvolvido visando à distribuição de produtos sistêmicos na cultura da batata, não solucionando a problemática das aplicações de moléculas produzidas para agirem como herbicidas pós-emergentes, fungicidas de contato e alguns tipos de inseticidas. Além disso, da mesma forma que o equipamento apresentado por Pereira (2001), o controle da altura dos emissores em relação ao alvo não pode ser realizado a todo instante, pois depende da movimentação de diversas abraçadeiras e parafusos.

Vieira (1994) afirma que o uso de sistemas de irrigação para aplicação de produtos químicos apresenta diversas vantagens sobre os métodos convencionais de aplicação, destacando-se a redução da compactação dos solos e dos danos mecânicos à cultura. Ressalta também que essa aplicação pode ser feita independentemente da altura e desenvolvimento das plantas. Dowler ${ }^{2}$, citado pelo mesmo autor, reporta que é possível utilizar essa técnica a qualquer hora do dia ou da noite, na ausência ou com a ocorrência de ventos fracos, e, em condições que impossibilitam o uso de tratores (solo umedecido) e avião (chuva e neblina).

\footnotetext{
${ }^{2}$ DOWLER, C.C. Chemigation. In: MATTHEWS, G.A.; HISLOP, E.C. (Ed.) Application technology
} for corn production. London: CAB International, 1993. p.317-327. 
Sistemas de pulverização que utilizam a estrutura aérea de um pivô central para o transporte da barra de pulverização podem apresentar essas mesmas vantagens, além de outras, tais como: economia de mão-de-obra, baixo custo operacional e menor consumo energético quando comparados aos sistemas tradicionais de pulverização, redução nos riscos de poluição ambiental e contaminações, e menor contato de partes metálicas do pivô com produtos capazes de potencializar o processo corrosivo.

\subsection{Parâmetros utilizados para caracterização do tamanho de gotas}

Carvalho (1995) informa que diâmetro mediano volumétrico (DMV) é o parâmetro mais freqüentemente utilizado para a caracterização do tamanho de gotas nas aplicações de defensivos agrícolas. Geralmente expresso em micrômetros $(\mu \mathrm{m})$, o DMV representa o diâmetro de gota que divide o volume pulverizado em duas partes iguais. $\mathrm{O}$ valor do DMV fica próximo das classes superiores das gotas amostradas, em razão de que poucas gotas grandes têm enorme influência no total do volume coletado. Quando o termo "diâmetro de gotas" é empregado sem qualquer outro tipo de referência, subentende-se que esteja referindo-se a valores de DMV (Matuo, 1990).

Outro parâmetro utilizado para caracterização do tamanho de gotas é o diâmetro mediano numérico $(\mathrm{DMN})$, o qual representa o diâmetro que divide o número de gotas produzidas em duas partes numericamente iguais. Como um pequeno número de gotas grandes contém mais líquido do que um grande número de gotas pequenas, o valor do DMV é sempre maior do que o DMN (Carvalho, 1995).

Matthews (1992) relata que o coeficiente de dispersão (r) foi proposto inicialmente por Johnstone ${ }^{3}$, citado por Matuo (1990), e expressa a uniformidade do conjunto de gotas, sendo obtido pela razão entre os parâmetros DMV e DMN. Segundo o autor, o espectro de gotas é considerado homogêneo quando o valor de $r$ é inferior a 1,4 , atendendo à especificação para ser enquadrado como "controlled drop application" (CDA). Informa também que essa condição raramente é alcançada em equipamentos

3 JOHNSTONE, D.R. Statistical description of spray drop size for controlled drop application. In SYMPOSIUM ON CONTROLLED DROP APPLICATION, Farnham Surrey, 1978. Proceedings. New York: BCPC, 1978. p.35-42. 
comuns, ocorrendo apenas sob determinadas condições operacionais e pulverizadores eletrostáticos.

\subsection{Importância do tamanho de gotas na aplicação de defensivos agrícolas}

Mathews (1992) reporta que as pulverizações apresentam espectro com grande número de gotas que, na maioria das vezes, apresentam diâmetro inferior a $500 \mu \mathrm{m}$. O tamanho de gotas, massa ou volume obtidos por intermédio do diâmetro têm grande importância para os pesticidas, tanto com relação a eficiência de aplicação como no sentido de reduzir os riscos contaminação ambiental. Relata também que a tendência atual é de aplicações com volumes e diâmetros menores, buscando-se maior cobertura e penetração na folhagem.

$\mathrm{Na}$ Tabela 2 encontra-se reproduzida a classificação apresentada por Ozeki \& Kunz (s.d.), para o diâmetro de gotas em classes de tamanhos e respectivas recomendações para a utilização de cada uma dessas classes.

Tabela 2. Classes de tamanho de gotas e respectivas recomendações.

\begin{tabular}{lrl}
\hline Classificação do tamanho de gota & \multicolumn{1}{c}{$\begin{array}{c}\text { DMV } \\
(\mu \mathrm{m})\end{array}$} & Recomendação \\
\hline Fina & $<200$ & Inseticidas \\
Média & $201-400$ & Inseticidas e fungicidas \\
Grossa & $401-600$ & Herbicidas residuais \\
Muito grossa & $>600$ & Herbicidas hormonais \\
\hline
\end{tabular}

Fonte: adaptado de Ozeki \& Kunz (s.d.).

De acordo com Tuck et al. (1997), a eficácia de um defensivo agrícola está relacionada com o tamanho de gotas com que o produto é aplicado. Segundo o autor, uma adequada e uniforme cobertura do alvo só é alcançada com gotas de menor tamanho. 
Holland et al. (1997) informam que gotas pequenas apresentam menores velocidades verticais quando comparadas a gotas de maior tamanho, podendo ser transportadas sob ação do vento e prejudicar a qualidade da aplicação.

Ozeki \& Kunz (s.d.) comentam que o tamanho de gotas é que estabelece o seu desempenho quanto à distância de deslocamento (deriva), penetração na folhagem e perda por evaporação.

Bode (1987) cita que gotas com diâmetros inferiores a $20 \mu \mathrm{m}$ podem evaporar em menos de $1 \mathrm{~s}$, o que corresponde a uma trajetória vertical de aproximadamente $2 \mathrm{~cm}$. $\mathrm{O}$ autor comenta que gotas com diâmetros superiores a $150 \mu \mathrm{m}$ apresentam resistência à evaporação muito maior do que as de tamanhos menores. Segundo suas informações, a razão primordial para explicação desse fato é a maior relação existente entre o volume e a área das gotas maiores.

Holland et al. (1997) relatam que gotas de menor tamanho, com diâmetros de aproximadamente $100 \mu \mathrm{m}$, maximizam a deposição de produtos sobre os alvos da pulverização, aumentando o nível de controle, reduzindo os custos com produtos químicos e minimizando a contaminação ambiental. Os autores comentam que gotas demasiadamente grandes podem causar desperdício do defensivo agrícola por não atingirem exatamente o alvo pretendido. Por outro lado, Tuck et al. (1997) reportam que gotas maiores são menos susceptíveis à ação dos ventos.

Nordbo (1992) acrescenta que a aplicação sob maiores volumes de pulverização, associada a gotas maiores, freqüentemente diminui a quantidade de ingrediente ativo retido na folha por causa do escorrimento da calda de sua superfície para outros pontos. O autor ainda ressalta que o espectro de gotas produzido por um determinado bocal é uma complexa função na qual estão envolvidas as propriedades físicas do líquido, seu diâmetro e a pressão de operação.

Segundo Bode (1987), o objetivo de evitar deriva e obter adequada cobertura é alcançado utilizando gotas com DMV compreendidos entre 101 e $400 \mu \mathrm{m}$. Esses tamanhos são classificados como gotas finas e médias, de acordo com a proposição de Ozeki \& Kunz (s.d.) (Tabela 1). 


\subsection{Técnicas para determinação do tamanho de gotas}

$\mathrm{Na}$ literatura encontra-se um expressivo número de técnicas diferenciadas para determinação do tamanho de gotas, incluindo fotografia em alta velocidade, uso de laser e análise de imagens, sendo as duas últimas as mais aplicadas na atualidade. A escolha de uma determinada técnica deve-se fundamentar em diversos fatores, tais como a disponibilidade do equipamento, custo das análises, grau de dificuldade e precisão dos resultados.

Tuck et al. (1997) reportam que técnicas que fazem uso de raios laser baseiam-se na difração do feixe luminoso quando em contato com a nuvem de gotas.

Alguns equipamentos que empregam raios laser permitem determinar, além do espectro de gotas, suas velocidades verticais. Essa particularidade os tornam interessantes tanto para estudos de pulverização como irrigação, hidrologia, ciências do solo, ciências florestais ou outras áreas afins (Particle Measuring Systems Inc., s.d.). Embora por meio desses equipamentos possam ser feitas análises precisas e em tempo real do espectro de gotas, o elevado custo restringe seu uso a poucos centros de pesquisas. Um aparelho dessa natureza, equipado com os respectivos acessórios que o acompanham, pode alcançar cifras da ordem de US $\$ 35,000.00$, além de outras despesas decorrentes da importação e necessidade de um computador, de acordo com Lima ${ }^{4}$.

Outra técnica utilizada para estudo de tamanhos de gotas, muito empregada no caso da pulverização, é a análise feita a partir de papéis sensíveis à água. Esses papéis, especialmente revestidos, são utilizados para avaliar a densidade e a distribuição de gotas, a largura da faixa de deposição e a penetração líquido pulverizado na folhagem. No papel sensível à água, de cor amarela, formam-se manchas azuis quando as gotas atingem sua superfície (Spray Systems Co., 1999).

Os papéis sensíveis foram desenvolvidos para análises rápidas em pulverizações com baixos volumes, encontrando-se disponíveis em três tamanhos diferentes (26x76, $52 \times 76$ e 26x500mm). Seu uso fica limitado quando o número de gotas é próximo de 200

${ }^{4}$ LIMA, L.A. (Universidade Federal de Lavras. Departamento de Engenharia. Lavras - MG). Comunicação pessoal, 1999. 
unidades por centímetro quadrado, o que corresponde a volumes de pulverização que variam entre 50 a 200L/ha para gotas classificadas como grossas e médias, respectivamente. A contagem do número de gotas pode ser feita pela análise visual, com auxílio de uma lente de aumento e um cartão no qual fora previamente aberta uma janela de tamanho conhecido, geralmente medindo $1 \mathrm{~cm}^{2}$. O tamanho das gotas, nesse caso, é determinado diretamente medindo-se a extensão da mancha no papel sensível ou, em casos de determinações expeditas, comparando-se visualmente os papéis sensibilizados com cartões-padrões onde são dispostos alguns diferentes tamanhos de gotas. Quando o objetivo é determinar diretamente no papel sensível o tamanho das gotas, recomenda-se que seja aplicado um fator de espalhamento. Esse fator, concebido pelo método padrão para determinação do tamanho de gotas (óxido de magnésio), visa a corrigir o diâmetro da gota em razão do espalhamento natural que ocorre quando essas alcançam a superfície do papel sensível (Ciba-Geigy, s.d.)

Carvalho (1995), objetivando comparar diferentes métodos de amostragem nas aplicações de produtos químicos, concluiu que o uso de papéis sensíveis é uma das melhores opções. Sua maior praticidade, quando comparado a outros métodos, também foi evidenciada pelo pesquisador.

Embora os resultados encontrados pelo autor citado anteriormente sejam positivos quanto ao emprego dos papéis sensíveis, avaliações feitas com essa técnica são laboriosas e estão sujeitas à subjetividade do avaliador.

Em razão dessas dificuldades, a EMBRAPA-CNPDIA, em parceria com o Instituto Agronômico de Campinas (IAC) e a Universidade Federal de São Carlos (UFSCAR), desenvolveram um sistema para análise de imagens denominado SADGNA (Sistema para Análise da Distribuição de Gotas Naturais e Artificiais), o qual é aplicado na automação da análise visual de distribuição de gotas. Esse programa computacional, denominado E-Sprinkle, foi melhorado e atualmente é comercializado pela Ablevision Sistemas Computacionais Ltda. mediante transferência de tecnologia da EMBRAPA. As imagens são processadas por meio de avançadas técnicas digitais, após a varredura dos cartões sensibilizados, que é feita com o uso de um scanner (resolução de 600dpi). Os resultados desse processamento permitem explicitar diversos parâmetros comumente 
empregados para caracterizar a aplicação de defensivos, tais como o DMV, DMN e o coeficiente de dispersão (r). O usuário pode optar pelo uso ou não dos fatores de espalhamento, caso esteja trabalhando com imagens de papéis sensíveis. O programa também permite análises de imagens tomadas em placas de Petry preenchidas com óleo. Essa técnica é utilizada por alguns pesquisadores para a avaliação de tamanhos de gotas provenientes de chuva ou irrigação (Ablevision Sistemas Computacionais Ltda., s.d.).

\subsection{Avaliação da uniformidade de distribuição da pulverização}

A distribuição da pulverização pode ser avaliada por meio de distintas técnicas, geralmente empregando água pura ou soluções que não ofereçam qualquer tipo de risco a pessoas e/ou contaminação ambiental.

Os fabricantes de pontas e pulverizadores, além de alguns centros de pesquisa e avaliação, dispõem de mesas de distribuição ou de pulverização. Esses amostradores possuem vários canais alinhados perpendicularmente à ponta de pulverização, os quais conduzem o líquido para provetas, onde são determinados volumes para posterior análise dos resultados (Spray Systems Co., 1999).

Cupery (1987) informa que a variabilidade da aplicação é usualmente avaliada por meio do coeficiente de variação $(\mathrm{CV})$, o qual representa o desvio padrão de uma amostra de valores expresso como porcentagem de sua média. $\mathrm{O}$ autor observa que o $\mathrm{CV}$ depende não somente dos equipamentos, materiais e condições de operação durante o teste, mas também da área, tempo de amostragem e das próprias amostras. De acordo com seus relatos, muitos pesquisadores consideram aceitáveis valores de $\mathrm{CV}$ inferiores a $15 \%$. Além disso, apresenta informações que sumarizam julgamentos de valores do CV, definidos por diversos autores, em diferentes países, cuja transcrição é apresentada na Tabela 3. 
Tabela 3. Julgamento dos valores CV considerados em diferentes países e número de referências bibliográficas citadas.

\begin{tabular}{lrlc}
\hline País & CV (\%) & Julgamento & Número de referências \\
\hline E.U.A. & $\leq 15$ & desejável & 99 \\
& $\leq 10$ & bom & \\
& $\leq 15$ & aceitável & 20 \\
& $\leq 10$ & recomendável & \\
Canadá & $\leq 15$ & aceitável & 82 \\
& $\leq 10$ & muito bom & \\
África do Sul & $>20$ & inaceitável & \\
& $12-20$ & regular & \\
& $9-12$ & bom & \\
& $<9$ & ótimo & \\
Escandinávia & $>20$ & inaceitável & \\
& $16-20$ & aceitável & \\
& $12-16$ & satisfatório & \\
& $10-12$ & muito bom & \\
& $<10$ & ótimo &
\end{tabular}

Fonte: adaptado de Cupery (1987).

Ramos (2001), em uma das poucas matérias que tratam do assunto no Brasil, reporta que uma distribuição uniforme ao longo da barra de pulverização deve apresentar valor de CV inferior a $10 \%$.

Buchleiter et al.(2001) comentam que valores CV inferiores a $15 \%$ são adequados para pulverizadores terrestres.

Gerling \& Solie ${ }^{5}$, citados por Cupery (1987), informam que os valores de CV obtidos sob condições controladas de laboratório geralmente são maiores do que os

\footnotetext{
${ }^{5}$ GERLING, J.F.; SOLIE, J.B. Effects of ground speed, nozzle spacing and nozzle height on nozzle
} spray patterns. St Joseph: ASAE,1984. 11p. (ASAE. Paper, 84-1501) 
observados no campo para as mesmas condições da aplicação. Taylor \& Meritt ${ }^{6}$, citados pelo mesmo autor, publicaram resultados de uma análise de distribuição realizada paralela e transversalmente ao sentido de deslocamento do pulverizador, com o objetivo de verificar qual seria a influência dessas diferentes distribuições nos valores de CV. Foram encontrados valores de CV da ordem de $17 \%$ para a distribuição espacial e 10\% para as demais.

Pelos resultados verificados pelos autores anteriormente citados, demonstra-se que, em situações nas quais os coletores encontram-se distribuídos espacialmente, é possível admitir valores de CV superiores aos observados nas mesas de distribuição (lineares). Além disso, o julgamento dos valores de CV varia, mas geralmente, no caso das pulverizações terrestres, são aceitos como satisfatórios quando inferiores a 15\%.

\footnotetext{
${ }^{6}$ TAYLOR, W.A.; MERIIT, C.R. Preliminary field trials with 2-4D ester triallate in spray volumes of 5 -
} 20L/ha. Weed Research, v.14, p. 245-250, 1974. 


\section{MATERIAL E MÉTODOS}

\subsection{Localização e etapas do experimento}

O desenvolvimento do sistema de pulverização proposto neste trabalho foi realizado em cinco etapas distintas. A primeira etapa constou do desenvolvimento da metodologia para dimensionamento do sistema de pulverização. A segunda etapa, na qual foram realizadas avaliações preliminares com alguns componentes do sistema de pulverização, ocorreu no Laboratório de Hidráulica do Departamento de Engenharia Rural (LER), situado no campus da Escola Superior de Agricultura "Luiz de Queiroz" (ESALQ), da Universidade de São Paulo (USP), no município de Piracicaba - SP. Nas terceira e quarta etapas, respectivamente, foram feitas a montagem e avaliação do equipamento. Essas etapas foram executadas em um pivô central instalado na Fazenda Areão, também situada em Piracicaba, vinculada e administrada pela ESALQ/USP. A quinta etapa refere-se ao desenvolvimento do programa computacional para dimensionamento de sistemas de pulverização acopláveis a pivôs centrais, com base na metodologia desenvolvida na primeira etapa e em alguns resultados observados nas terceira e quarta etapas.

O sistema de pulverização, por se tratar de um protótipo e também por razões econômicas, foi instalado apenas na terceira torre do pivô central. Ressalta-se que os resultados observados na terceira torre podem ser extrapolados para as demais, uma vez que os comprimentos dos vãos, velocidades dos sistemas de deslocamento e metodologia de dimensionamento são os mesmos.

Todas as avaliações foram feitas com água pura, como sugerido para ensaios de pulverização. 


\subsection{Referencial ideológico}

O protótipo do equipamento de pulverização desenvolvido neste trabalho foi concebido com base no sistema Notliada proposto por Dourado Neto \& Fancelli (1999). As principais diferenças estão relacionadas aos emissores utilizados, à dupla barra de pulverização e à intermitência do sistema de pulverização, a qual proporciona expressiva redução do volume de calda aplicado.

\subsection{Avaliações preliminares}

Realizaram-se avaliações preliminares com o propósito de orientar tanto a escolha dos emissores, como seus desempenhos em determinadas situações.

\subsubsection{Escolha dos emissores}

A concepção deste projeto foi desenvolver um sistema de pulverização intermitente, no qual a barra de pulverização é acionada por alguns instantes durante o deslocamento do pivô central. Sob essa ótica, buscou-se, inicialmente, identificar no mercado pontas de pulverização capazes de produzir jatos cônicos cheios. A expectativa era de que esses modelos de pontas poderiam apresentar razoável uniformidade de distribuição quando submetidas à sobreposição nos momentos de deslocamento da barra de pulverização no campo. O modelo escolhido para essa avaliação foi o Teejet DiscCore, fabricado pela empresa norte-americana Spray Systems Co. ${ }^{7}$

Essas pontas de pulverização foram adquiridas e montadas no interior de corpos para bicos, acompanhando a seqüência designada pelo fabricante: filtro ranhurado (4514-NY), difusor cerâmico (DC-33), ponta de pulverização (DCER-2) e capa para bico (CP26277-1-NY).

\footnotetext{
${ }^{7}$ O uso de produtos ou marcas registradas tem a finalidade exclusiva de facilitar a compreensão do leitor, não constituindo endosso por parte dos autores e instituições ou críticas a produtos similares não citados.
} 
Cinco corpos para bicos completos foram preparados e instalados em uma tubulação de PVC rígido roscável, com diâmetro de 25mm (3/4”). Nessa tubulação também foram instalados um filtro de 120 mesh e um registro de gaveta em uma das extremidades, objetivando eliminar o risco de possíveis entupimentos e o controle da pressão de operação. Na extremidade oposta, adaptou-se uma tomada de pressão, por onde também realizou-se a escorva dessa canalização. O espaçamento e a altura de instalação adotados foram de $50 \mathrm{~cm}$, conforme orientação do fabricante.

Submeteram-se as pontas de pulverização a pressões que variaram de $100 \mathrm{a}$ $400 \mathrm{kPa}$. Ressalta-se que esses valores encontram-se dentro da faixa de pressão de operação recomendada pelo fabricante dessas pontas, e pressões acima de $400 \mathrm{kPa}$ não seriam interessantes por superar a pressão máxima recomendada para outros componentes plásticos que constituiriam o sistema de pulverização.

Outro modelo de emissor escolhido para novas avaliações foi o nebulizador modelo Fogger 7800, fabricado pela empresa israelense Dan Sprinklers. Esses equipamentos, embora empregados usualmente na irrigação e/ou controle de temperatura e umidade relativa no interior de ambientes protegidos, produzem gotas relativamente pequenas e podem ser facilmente instalados em tubos de PVC.

A estrutura utilizada para os ensaios desses emissores foi praticamente a mesma usada no modelo avaliado anteriormente. Substitui-se apenas a barra de pulverização, inalterando-se o espaçamento e altura de instalação. A pressão de serviço foi de $300 \mathrm{kPa}$ para os quatro modelos comerciais disponíveis avaliados, todos equipados com válvulas antigotas.

Embora os resultados apresentados por todos os bocais do Fogger 7800 tenham sido satisfatórios, contrariamente às pontas fabricadas pela Spray Systems, novos ensaios objetivando avaliar a resposta hidráulica foram realizados com o primeiro modelo. 


\subsubsection{Avaliação da resposta hidráulica dos nebulizadores Fogger $\mathbf{7 8 0 0}$}

O circuito preparado para a avaliação da resposta hidráulica dos emissores foi composto de reservatório, conjunto motobomba, filtro $120 \mathrm{mesh}$, válvula reguladora de pressão, válvula solenóide, tubos de PVC rígido roscável, válvulas antigotas, emissores e registro, além de conexões hidráulicas necessárias à sua complementação. Esclarece-se que todos esses componentes são idênticos aos empregados no modelo final da barra de pulverização e suas descrições, portanto, coincidem com as apresentadas no item 3.5.

Cinco emissores foram dispostos, a cada $6 \mathrm{~m}$, em toda a extensão da tubulação, a qual apresentou comprimento total de $30 \mathrm{~m}$. $\mathrm{Na}$ extremidade final instalou-se um registro, com a finalidade de permitir sua escorva.

Estabeleceu-se a intermitência dos emissores mediante o emprego de uma válvula solenóide, responsável pelo controle do fluxo líquido para a tubulação. Essa válvula foi acionada por meio de um periférico, cujo esquema do circuito eletrônico é apresentado na Figura 2.

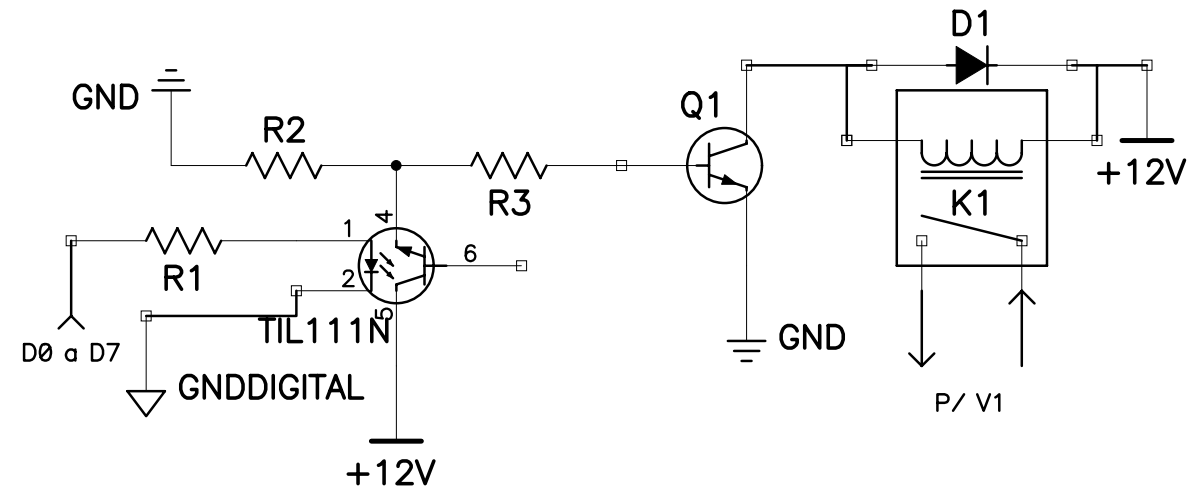

D1: diodo 1N4007

D0 a D7: pinos 2 a 9 da PP

$\mathrm{K} 1$ : relé $12 \mathrm{Vcc} / 50 \mathrm{~mA}$

R1: resistor $330 \Omega$

Q1: transistor BC548

V1: válvula solenóide

R2 e R3: resistor $10 \mathrm{k} \Omega$

GNDDIGITAL: pinos 18 a 25 da PP

TIL111N: acoplador ótico

Figura 2 - Esquema do circuito eletrônico do periférico utilizado para acionamento da válvula solenóide, por meio da porta paralela (PP) de um microcomputador, durante a realização dos ensaios preliminares. 
O controle do periférico foi efetuado pela porta paralela de um microcomputador, usualmente empregada para instalação de impressoras. No computador foi instalado um programa computacional, desenvolvido em ambiente Delphi vs. 3.0 especificamente para essa finalidade (Anexo A). Os sinais digitais enviados por qualquer um dos pinos de saída da porta paralela (D0 a D7, que correspondem aos pinos 2 a 9 da saída DB25F destinada à conexão da impressora no computador), foram transmitidos ao periférico que, por meio de um relé, estabeleceu o contato elétrico necessário ao acionamento da válvula. O programa, da maneira que foi concebido, permitiu realizar simulações com tempos de abertura de até $0,1 \mathrm{~s}$.

Terminada essa fase experimental, determinou-se que a próxima deveria contemplar a avaliação de uma barra idêntica ao modelo definitivo que viria posteriormente a ser instalado no pivô central.

\subsubsection{Desenvolvimento e avaliação do protótipo da barra de pulverização}

No projeto do protótipo da barra de pulverização, foram observados todos os detalhes e metodologias que serão descritos a seguir nos itens 3.5 e 3.8. Assim, esse protótipo foi produzido em total semelhança com as barras montadas posteriormente no pivô central, excetuando-se a válvula reguladora de pressão que, nessa avaliação, foi substituída por um outro exemplar (modelo Série 60, diâmetro $32 \mathrm{~mm}$, fabricada pela empresa nacional Hiter S.A), o qual permite o ajuste da pressão em sua saída. Na Figura 3 pode-se observar o referido protótipo em operação.

O fluxo de entrada da barra foi controlado da mesma forma comentada no item anterior e a pressão nesse ponto ajustada para $211 \mathrm{kPa}$ (30psi). Esclarece-se que esse valor coincide com a pressão de saída da válvula reguladora empregada no sistema de pulverização. 

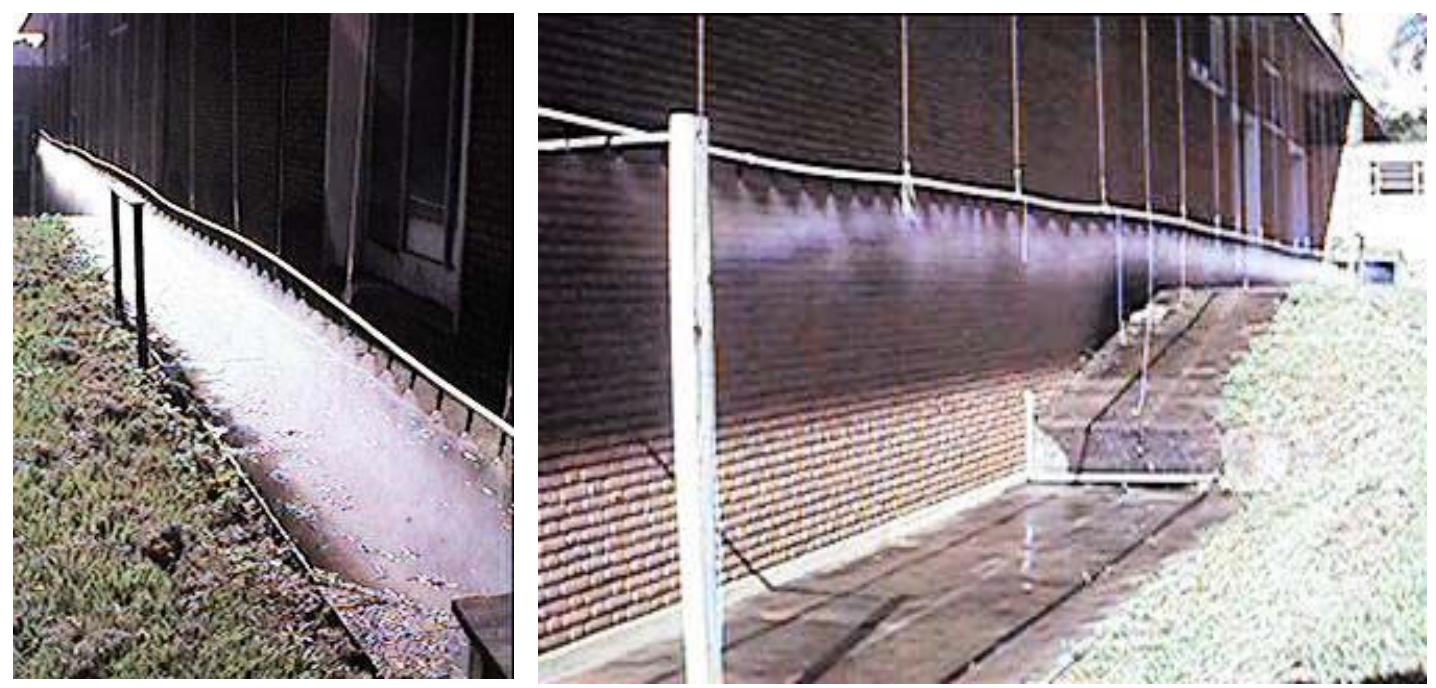

Figura 3 - Aspecto geral do protótipo da barra de pulverização montado em laboratório.

\subsection{Características do pivô central}

O protótipo do sistema de pulverização desenvolvido neste trabalho foi montado em um sistema de irrigação por aspersão mecanizada, tipo pivô central, instalado em 1988 na área experimental da Fazenda Areão reservada ao Departamento Engenharia Rural da ESALQ/USP.

As principais especificações técnicas do sistema de irrigação encontram-se descritas no Apêndice 1.

\subsection{Componentes do sistema hidráulico da barra de pulverização}

O sistema hidráulico foi composto das seguintes partes: conjunto de emissão, barra de pulverização, válvula solenóide, tubulação de alimentação, válvula reguladora de pressão, tubulação de distribuição, sistema de pressurização e filtragem, além dos reservatórios. Algumas dessas partes são formadas pela associação de outros elementos, cujos detalhes serão apresentados na seqüência. 


\subsubsection{Conjunto de emissão}

Basicamente três elementos formaram o conjunto de emissão (Figura 4): emissor, dispositivo antidrenante (válvula antigota) e conector.

Todos os ensaios relacionados ao conjunto de emissão foram realizados no interior do Laboratório de Hidráulica do Departamento de Engenharia Rural da ESALQ/USP, o qual é dotado de circuitos hidráulicos, conjuntos de bombeamento e filtros, além de outros equipamentos que possibilitam a realização de ensaios dessa natureza.

Procedeu-se à filtragem da água em um filtro de discos, no qual as alturas das ranhuras para passagem de água equivalem a aberturas de telas com 120mesh.

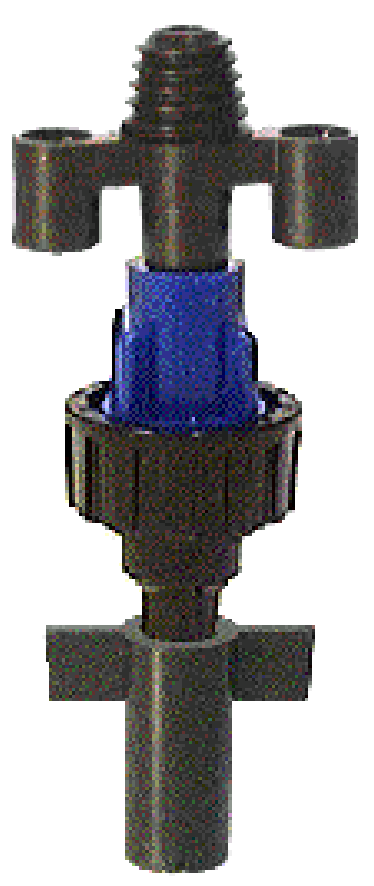

(a)

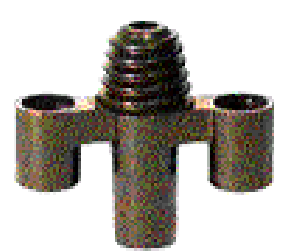

(b)

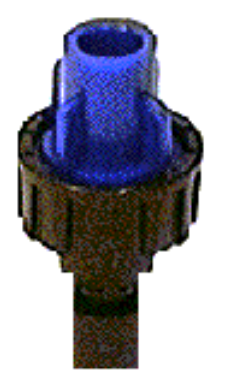

(c)

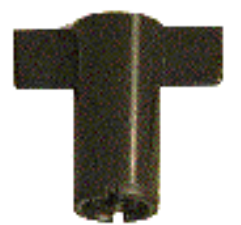

(d)

Figura 4 - Componentes do conjunto de emissão: conjunto completo (a), conector (b), dispositivo antidrenante (c), emissor (d). 


\subsubsection{Emissores}

Foram utilizados emissores Fogger 7800 (Figura 4d) como elementos formadores de gotas na barra de pulverização.

Esses emissores dispõem de quatro diferentes modelos de bocais intercambiáveis, cujas características são apresentadas na Tabela 4. Os bocais foram montados no interior de corpos plásticos que, por sua vez, foram encaixados por simples pressão nos dispositivos antidrenantes.

Tabela 4. Codificação por cores, diâmetros e vazões nominais dos bocais Fogger 7800 .

\begin{tabular}{lcc}
\hline Cor & $\begin{array}{c}\text { Diâmetro } \\
(\mathrm{mm})\end{array}$ & $\begin{array}{c}\text { Vazão nominal }^{* *} \\
(\mathrm{~L} / \mathrm{h})\end{array}$ \\
\hline Azul & 0,317 & 7 \\
Vermelho & 0,508 & 14 \\
Laranja & 0,513 & 21 \\
Preto & 0,614 & 28 \\
\hline
\end{tabular}

"Determinados no Laboratório de Hidráulica do Departamento de Engenharia Rural da ESALQ/USP.

${ }^{* *}$ De acordo com o fabricante, sob pressão de $400 \mathrm{kPa}$.

Os diâmetros dos bocais, cujos valores não são informados nos catálogos disponibilizados pelo fabricante, foram mensurados em projetor ótico modelo HB400-2, fabricado pela empresa britânica Starret Precision Optical, empregando-se lâmpada apropriada à projeção de perfil (tungstênio halógena). O referido projetor, instalado no Laboratório de Hidráulica do Departamento de Engenharia Rural da ESALQ/USP, encontra-se interligado a um microcomputador que possui um programa, fornecido pelo fabricante do projetor, que exprime o valor da medição realizada. Os diâmetros informados na Tabela 4 representam médias de dez valores observados para cada um dos quatro modelos de bocais disponíveis comercialmente. 


\section{Perfil de distribuição da precipitação}

Para a determinação do perfil de distribuição da precipitação, montou-se uma estrutura onde cada um dos emissores foi avaliado de maneira isolada. Essa estrutura permitiu posicionar o emissor a uma altura de $50 \mathrm{~cm}$ da borda dos coletores, os quais foram colocados sobre a superfície do piso do laboratório.

A distribuição de coletores na área foi feita em formato radial, dispondo-se um dos coletores na interseção de duas linhas ortogonais, exatamente sob o emissor. Em cada uma dessas linhas, foram colocados 10 coletores, além do que se encontrava sob o emissor, igualmente espaçados de $10 \mathrm{~cm}$ (Figura 5).

$10 \mathrm{~cm}$

Coletor

Emissor

Figura 5 - Esquema da disposição dos coletores para determinação do perfil de distribuição.

Foram utilizados coletores plásticos fabricados pela empresa Fabrimar, com diâmetro e altura de $8 \mathrm{e} 10 \mathrm{~cm}$, respectivamente. 
A pressão foi ajustada mediante um registro instalado na entrada da tubulação e monitorada por meio de um manômetro digital marca Zurich, modelo Z-10, com fundo de escala de $1.000 \mathrm{kPa}\left(10 \mathrm{kgf} / \mathrm{cm}^{2}\right)$ e capacidade de leitura de $10 \mathrm{kpa}\left(0,1 \mathrm{kgf} / \mathrm{cm}^{2}\right)$.

Foram avaliadas 3 unidades de cada modelo de bocal, perfazendo um total de 12 ensaios. Em todos os ensaios, a pressão de serviço foi mantida em $211 \mathrm{kPa}$.

Por causa da pequena capacidade volumétrica dos coletores e da elevada intensidade de precipitação em alguns pontos do raio molhado, cada ensaio teve duração limitada a $15 \mathrm{~min}$.

Mensuraram-se os volumes coletados, em cada posição, mediante provetas com capacidade de $100 \mathrm{~mL}$ e precisão de leitura de $1 \%$. Valores inferiores a $1 \mathrm{~mL}$ foram descartados, de maneira a considerar, nesse ponto, o alcance máximo do emissor.

Com base nos volumes coletados, determinou-se a intensidade de precipitação em cada um dos pontos, considerando a área de abertura do coletor, o volume armazenado e a duração do ensaio. A média dos resultados de cada posição, para um determinado tipo de bocal, foi considerada como representativa para todos os pontos radialmente posicionados na mesma distância.

As equações para representação dos perfis de distribuição médios, para cada um dos modelos de bocais avaliados, foram obtidas por meio de um programa computacional específico para essa finalidade.

\section{Relação pressão-vazão}

A determinação da relação pressão versus vazão foi feita com base na norma ISO9260:1991(E) (International Standart Organization, 1991). Determinou-se a vazão média de cada um dos quatro modelos de bocais disponíveis, equipados com válvulas antigotas, sob pressões de 110,150, 200 e $250 \mathrm{kPa}$. As médias de todas as vazões e as respectivas pressões com as quais obtiveram-nas foram ajustadas, por meio de regressão (anamorfose), obtendo-se os parâmetros da seguinte equação:

$$
q=K . H^{x}
$$


em que $q(\mathrm{~L} / \mathrm{h})$ é a vazão do emissor; $K\left(\mathrm{~L} / \mathrm{h} \cdot \mathrm{kPa}^{-\mathrm{x}}\right)$ o coeficiente de ajuste da equação; $H(\mathrm{kPa})$ a pressão de operação e; $x$ (adimensional) o expoente característico do emissor.

Para a determinação dos pares de valores requeridos para a obtenção da eq. (1), preparou-se uma tubulação de PVC, com diâmetro de $25 \mathrm{~mm}$ (3/4"), na qual foram instalados vinte e cinco conjuntos de emissão, número mínimo recomendado pela norma ISO9260:1991(E). O espaçamento adotado para esses conjuntos foi de $12 \mathrm{~cm}$. Em uma das extremidades dessa tubulação, instalou-se uma tomada de pressão, cujo objetivo, além de possibilitar o acoplamento do manômetro, foi propiciar a escorva total da barra e de seus componentes. Na extremidade oposta, utilizada como entrada de água para a tubulação, conectou-se um registro de $25 \mathrm{~mm}$ (3/4") do tipo gaveta. Esse registro possibilitou o controle da entrada de fluxo para o tubo, e, conseqüentemente, o ajuste da pressão de operação dos emissores. Mangueiras de polietileno da baixa densidade (PEBD), com diâmetro nominal de $16 \mathrm{~mm}$, complementaram a ligação da tubulação ao circuito hidráulico do laboratório.

Desenvolveu-se uma estrutura, na forma de um cavalete, para a fixação da barra e seus acessórios, incluindo-se os conjuntos de emissão. Um "carrinho", também concebido para avaliações dessa natureza, foi colocado sob a estrutura. Esse equipamento possuía quatro rodas que favoreceram seu deslocamento sobre trilhos dispostos no piso do laboratório. O sistema de movimentação foi desenvolvido com o intuito de facilitar a realização do ensaio, além de eliminar possíveis erros no início e final de cada coleta, contribuindo favoravelmente para a precisão dos resultados.

As vazões dos conjuntos de emissão foram determinadas pelo método direto. $\mathrm{O}$ líquido, proveniente de cada um dos emissores, foi disposto em coletores com capacidade volumétrica de aproximadamente $1,8 \mathrm{~L}$, manufaturados a partir de garrafas plásticas de refrigerantes (tipo "pet"). Conduziu-se o fluxo dos emissores até a abertura dos coletores por meio de segmentos de tubos de PEBD, com diâmetro e comprimento aproximados de 16 e $200 \mathrm{~mm}$, respectivamente.

O conteúdo dos coletores foi pesado em balança eletrônica, obtendo-se os respectivos volumes considerando a densidade da água igual à unidade. A precisão dos 
equipamentos utilizados é de centésimos de grama e de segundos, respectivamente para a balança e o cronômetro.

Os tempos de coleta dependeram tanto do modelo do emissor como da pressão de operação, limitando-se entre 5 e 12min. Na prática, aguardava-se até que aproximadamente $3 / 4$ do volume do coletor estivesse totalmente preenchido com líquido, estabelecendo-se o tempo para a coleta desse volume.
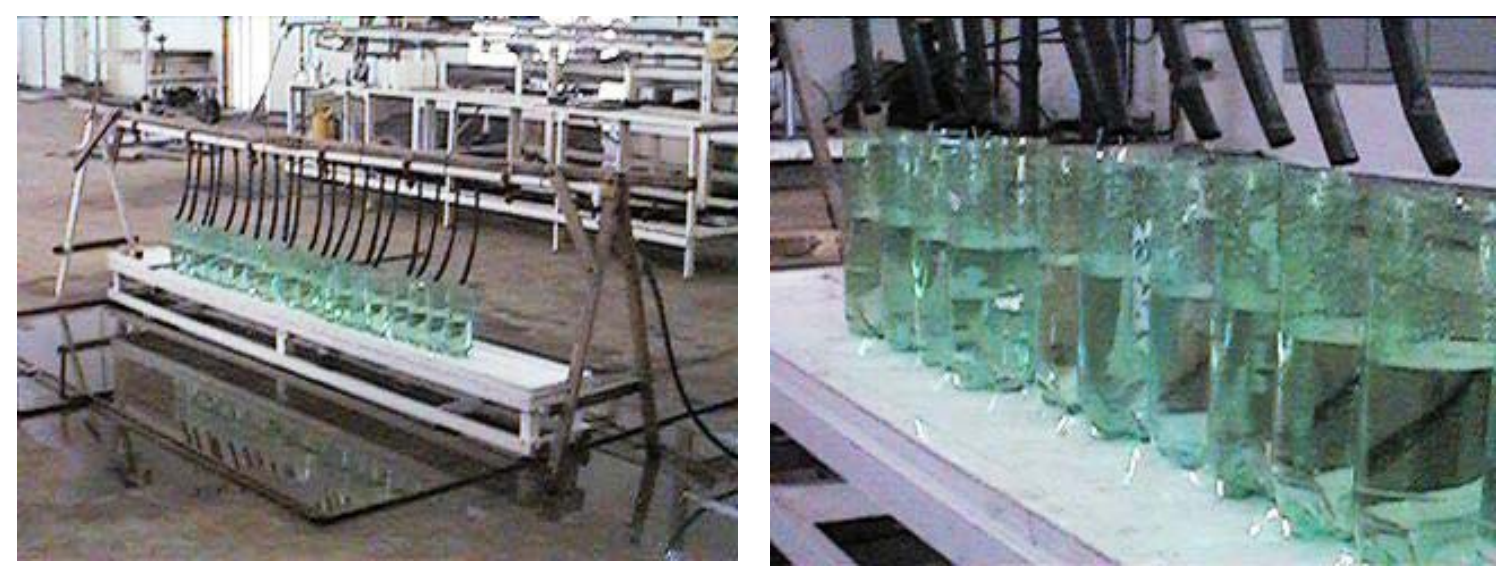

Figura 6 - Estrutura desenvolvida para avaliação das vazões dos emissores.

\section{Coeficiente de variação de fabricação}

Os coeficientes de variação de fabricação dos emissores (CVF) foram calculados com base na expressão sugerida por Solomon (1979):

$$
C V F=\frac{s_{q}}{q_{m}} \cdot 100
$$

em que $C V F(\%)$ é o coeficiente de variação de fabricação; $s_{q}(\mathrm{~L} / \mathrm{h})$ o desvio padrão da vazão dos emissores contidos na amostra e; $q_{m}(\mathrm{~L} / \mathrm{h})$ a vazão média dos emissores contidos na amostra .

Os emissores foram classificados de acordo com a proposta do Soil Conservation Service (USDA), reproduzida na Tabela 5. 
Tabela 5. Recomendação para classificação de emissores quanto ao CVF.

\begin{tabular}{cl}
\hline $\mathrm{CVF}(\%)$ & Classificação \\
\hline $\mathrm{CVF} \leq 5$ & Uniformidade excelente \\
$5<\mathrm{CVF} \leq 7$ & Uniformidade média \\
$7<\mathrm{CVF} \leq 11$ & Uniformidade marginal \\
$11<\mathrm{CVF} \leq 15$ & Uniformidade pobre \\
$\mathrm{CVF}>15$ & Inaceitáveis \\
\hline
\end{tabular}

Fonte: adaptado de Estados Unidos (1979).

Considerando apenas um modelo de emissor, determinaram-se valores de CVF baseando-se nas vazões obtidas para cada uma das quatro pressões que os emissores foram submetidos. A média desses quatro valores foi considerada como o valor do CVF médio do emissor.

\subsubsection{Dispositivos antidrenantes}

Em todos os conjuntos de emissão foram instaladas válvulas antidrenantes, também conhecidas por válvulas antigotas.

Tais dispositivos foram incorporados ao conjunto com o intuito de atender a dois objetivos distintos: o primeiro deles foi evitar a formação de gotas nas extremidades externas dos bocais nos momentos em que a pulverização não estivesse ocorrendo, o que eliminaria possibilidades de o alvo pulverizado receber quantidades de defensivos agrícolas incontroladas; o segundo objetivo foi manter a barra de pulverização totalmente preenchida com líquido nos momentos em que não estivesse em operação. Isso proporcionaria respostas hidráulicas mais rápidas, possibilitando a abertura dos dispositivos antidrenantes quase que simultaneamente à abertura do fluxo para a barra, o que poderia contribuir favoravelmente para a uniformidade de aplicação. Para que isso ocorresse, houve a necessidade de escorvar- se previamente a barra de pulverização. 
Empregaram-se válvulas antigotas denominadas L.P.D. (Leakage Prevention Device), modelo "baixa pressão", codificadas pela cor preta, produzidas pelo mesmo fabricante dos emissores. De acordo com as informações disponibilizadas pela empresa, as pressões de fechamento e abertura desses modelos de válvulas são de 70 e $200 \mathrm{kPa}$ (0,7 e 20bar), respectivamente.

Essas válvulas possuem extremidades lisas, com encaixes do tipo ponta e bolsa, os quais possibilitam seu acoplamento aos emissores e aos conectores.

\subsubsection{Conectores}

A ligação do conjunto formado pelos emissores e válvulas antigotas à barra de pulverização foi efetuada por meio de conectores específicos para essa finalidade, denominados "butterfly treaded $3 / 8$ ", também produzidos pelos mesmos fabricantes dos emissores e válvulas antigotas.

Esses conectores possuem uma das extremidades lisa, na qual é acoplada a válvula antigota. A extremidade oposta, própria para a fixação dessa em tubulações, é dotada de rosca cônica com diâmetro de $9 \mathrm{~mm}(3 / 8$ ").

Os conectores foram fixados à barra de pulverização da seguinte maneira: mediante uma broca, com diâmetro de $8 \mathrm{~mm}$, fez-se uma abertura na tubulação que constitui a barra, na qual providenciou-se uma rosca tipo "witworth", utilizando para essa tarefa um macho cilíndrico com diâmetro de $6 \mathrm{~mm}$. Essa ferramenta foi instalada em uma furadeira manual com controle de velocidade e sentido de rotação. Embora o tipo de rosca feita no tubo e no conector não fossem exatamente iguais, a conexão pôde ser realizada satisfatoriamente, aplicando-se silicone no ato da montagem dessas partes com a finalidade de eliminar possíveis vazamentos.

Um conjunto de gabaritos foi desenvolvido com objetivo de alinhar os furos da barra de pulverização, o qual foi composto por três elementos. Um desses elementos constou de uma base, sobre a qual foi soldada uma cantoneira 19 x $3 \mathrm{~mm}(3 / 4 \times 1 / 8$ ") e $20 \mathrm{~cm}$ de comprimento, voltada para cima, formando um suporte. Fixou-se esse suporte por meio de parafusos na base de uma furadeira radial, de maneira que o centro 
geométrico da cantoneira coincidisse exatamente com o alinhamento vertical da broca. O emprego desse gabarito permitiu que todos os furos fossem realizados perpendicularmente à tubulação. Os outros dois elementos que compõem o conjunto de gabaritos são exatamente iguais e formados por duas cantoneiras, com as mesmas dimensões da citada anteriormente, voltadas uma para outra, de maneira a fixar a tubulação entre essas. Nas laterais dessas cantoneiras foram soldadas pequenas chapas formando "asas", utilizadas para fixar uma cantoneira à outra, mediante parafusos e porcas de $6 \mathrm{~mm}$. No vértice das laterais de uma das cantoneiras, soldou-se perpendicularmente uma chapa (ferro chato $25 \times 3 \mathrm{~mm}$ ou 1 x $1 / 8$ ") com $15 \mathrm{~cm}$ de comprimento, constituindo a base dessa peça. Esses dois gabaritos, quando presos à tubulação, no ato da abertura dos furos, e deslocando-se sobre o piso do local, garantiram o perfeito alinhamento longitudinal desses ao longo da tubulação. Para a realização das aberturas, a furadeira foi disposta sobre a superfície de um piso nivelado. Os espaçamentos entre os furos, resultantes do dimensionamento da barra de pulverização, foram previamente demarcados sobre os tubos.

\subsubsection{Barra de pulverização}

A barra de pulverização foi confeccionada utilizando-se tubos de PVC rígido roscável, fabricados pela empresa nacional Fortilit S.A., com diâmetro nominal de $25 \mathrm{~mm}$ (3/4") e interno de $20,7 \mathrm{~mm}$, atendendo às especificações de norma para enquadramento na Classe de Pressão 15.

Todas as conexões e acessórios hidráulicos empregados na barra de pulverização também foram de PVC.

O comprimento das barras foi de $30 \mathrm{~m}$ e na extremidade final conectou-se um registro, objetivando promover a escorva da tubulação. Na extremidade oposta, por onde foi feita a alimentação da barra, dispôs-se uma válvula solenóide.

Os conjuntos de emissão foram instalados ao longo da barra de pulverização, obedecendo-se rigorosamente ao posicionamento e ao diâmetro dos bocais determinados para cada ponto de emissão. 
Todo o sistema de pulverização foi montado apenas no terceiro vão de torres do pivô central (item3.8). De acordo com o projeto concebido para esse sistema, cada vão de torres deve possuir duas barras de pulverização. Uma delas inicia-se nas adjacências da torre de sustentação situada mais próxima ao centro do pivô, prolongando-se por uma distância de $30 \mathrm{~m}$ em direção à extremidade final do equipamento de irrigação. A outra barra tem início na torre de sustentação subseqüente do vão em questão, prolongando-se também pela mesma distância, porém, em direção contrária.

Essas duas barras foram fixadas, por meio de abraçadeiras plásticas, a um cabo de aço estirado entre as duas torres de sustentação do referido vão. A Figura 7 ilustra os detalhes da barra de pulverização.
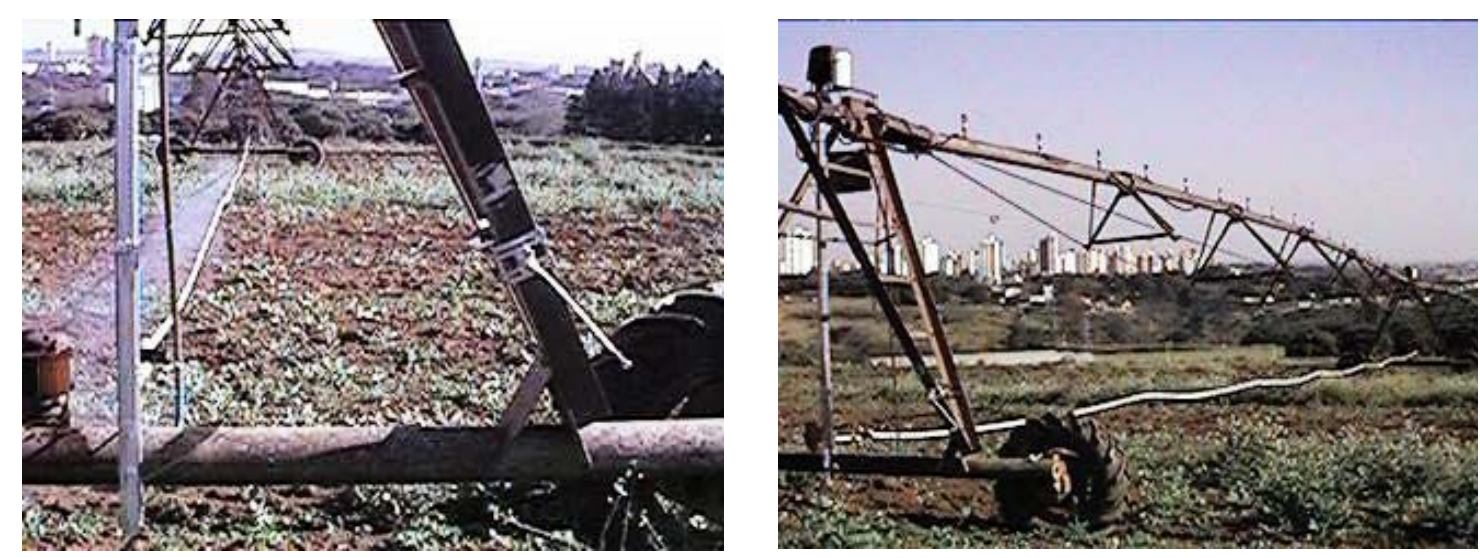

Figura 7 - Aspectos da montagem da barra de pulverização.

\subsubsection{Válvula solenóide}

$\mathrm{Na}$ entrada de cada uma das barras de pulverização, instalou-se uma válvula solenóide, objetivando controlar o fluxo hidráulico proveniente da tubulação de alimentação para a barra, de maneira a produzir o efeito de intermitência do sistema de pulverização.

As válvulas utilizadas são do modelo AA144A-1, fabricadas pela Spray Systems Co., e usualmente empregadas em pulverizadores agrícolas. São do tipo "normalmente 
fechada", e quando submetidas a uma diferença de potencial elétrico de $12 \mathrm{~V}$, em regime de corrente contínua, abrem-se quase que instantaneamente, permitindo a passagem do líquido pela sua câmara interna. De acordo com o fabricante, essa válvula demanda uma corrente elétrica de 2,5A para ser acionada.

O sinal elétrico para sua operação provém do circuito eletro-eletrônico descrito a seguir no item 3.7 .

\subsubsection{Tubulação de alimentação}

Em razão da possibilidade de controle da altura da barra de pulverização, procedeu-se à alimentação dessa por intermédio de uma tubulação flexível, a qual foi denominada tubulação de alimentação.

Foi utilizada para estabelecer a ligação entre a saída da válvula reguladora de pressão e a entrada da válvula solenóide.

A tubulação empregada foi fabricada pela empresa brasileira Petiflex S.A., modelo Peti Rubber, com diâmetro nominal de 25mm (3/4").

\subsubsection{Válvula reguladora de pressão}

Por causa das possíveis variações de pressão que podem ocorrer no circuito hidráulico, em decorrência das alterações de vazões provenientes da intermitência do sistema de pulverização e do tipo de bomba utilizado, empregou-se uma válvula reguladora de pressão no início de cada tubulação de alimentação.

Empregaram-se válvulas modelo Exact-30, fabricadas pela empresa nacional Fabrimar S.A. Foram posicionadas entre as tubulações de alimentação e distribuição, sobre cada uma das torres móveis que compõem o vão do pivô no qual instalou-se o equipamento de pulverização.

De acordo com o fabricante, a pressão de entrada pode variar entre 211 e $844 \mathrm{kPa}$ (30 a 120 psi). A pressão regulada na saída é de $211 \mathrm{kPa}$, quando se opera sob vazões de 0,4 a $4,5 \mathrm{~m}^{3} / \mathrm{h}$. 


\subsubsection{Tubulação de distribuição}

Essa denominação foi dada à tubulação responsável por conduzir o líquido do centro do pivô aos pontos onde foram instaladas as válvulas reguladoras de pressão.

Empregaram-se tubos de PEBD, com diâmetro de $32 \mathrm{~mm}$ e pressão nominal de $400 \mathrm{kPa}(\mathrm{PN} 40)$.

A tubulação de distribuição tem início logo após o filtro instalado na saída do conjunto motobomba, pertencente ao sistema de pressurização, situado próximo ao centro do pivô. Desse ponto, sobe verticalmente até alcançar a tubulação aérea do equipamento de irrigação, passando a ser conduzida horizontalmente sobre essa. A tubulação de distribuição foi disposta alternadamente, ora do lado esquerdo, ora do lado direito, dos pontos de saída de água da tubulação aérea do pivô, eliminando a necessidade de qualquer dispositivo para sua fixação.

O comprimento da tubulação de distribuição foi de $81 \mathrm{~m}$ até o ponto de instalação da primeira válvula reguladora de pressão, seguindo por mais $40 \mathrm{~m}$ até a segunda válvula reguladora de pressão, perfazendo um comprimento total de $121 \mathrm{~m}$.

\subsubsection{Sistema de pressurização e filtragem}

Este sistema é dotado de uma motobomba e um filtro de discos, cujas informações constam na Tabela 6 , além de acessórios hidráulicos complementares às suas instalações. 
Tabela 6. Características dos componentes do sistema de pressurização.

\begin{tabular}{lll}
\hline Elemento & Características & Descrição \\
\hline Motobomba & Fabricante & Ind. Mark Bras. \\
Modelo & DM 4 \\
Diâmetro da tubulação de sucção & $32 \mathrm{~mm}\left(1{ }^{\prime \prime}\right)$ \\
& Tipo de sucção & Positiva \\
Altura de instalação média & $45 \mathrm{~cm}$ \\
Potência do motor & $735,5 \mathrm{~W}(1 \mathrm{cv})$ \\
Rotação & $3500 \mathrm{rpm}$ \\
Filtro & Tensão de alimentação & $440 \mathrm{Vca}$ \\
& Fabricante & Azud \\
& Modelo & A-25A \\
& Diâmetro nominal & $25 \mathrm{~mm}(3 / 4 ”)$ \\
& Elemento de filtragem & Discos \\
& Equivalência de abertura & $120 \mathrm{mesh}$ \\
\hline
\end{tabular}

O conjunto motobomba foi disposto sobre uma estrutura, a uma altura de $1 \mathrm{~m}$ da superfície do solo, ao lado do reservatório de captação e próxima ao centro do pivô, como pode ser observado na Figura 8.

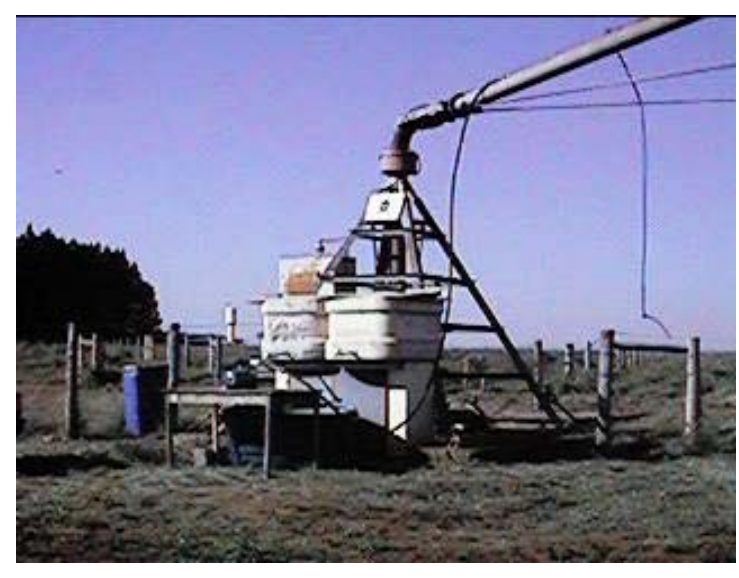

(a)

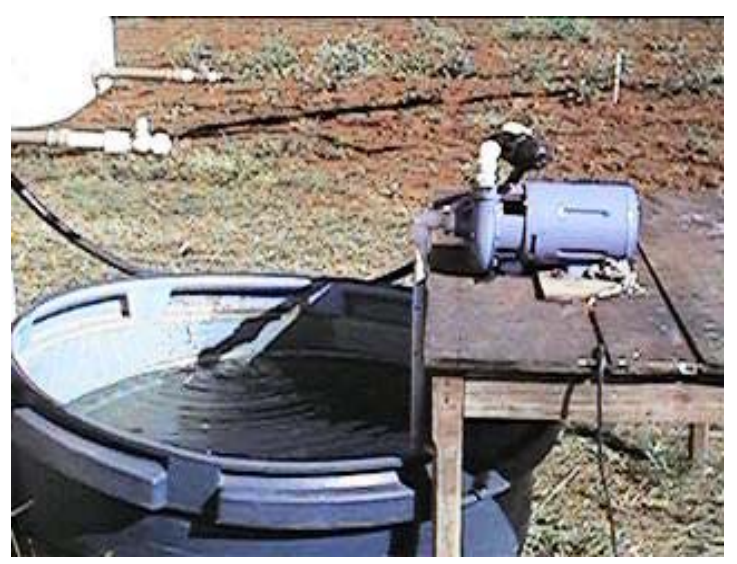

(b)

Figura 8 - Vista do sistema de pressurização (a) e reservatório de captação (b). 
A ligação do filtro à tubulação de distribuição foi feita com uma união de PVC, com diâmetro de $32 \mathrm{~mm}$ (1"), com intuito de possibilitar que essa canalização fosse desconectada, de uma maneira simples e rápida, nos momentos em que o sistema de pulverização não estivesse em operação. Da mesma forma dar-se-ía a conexão dos elementos citados, quando necessário.

A energia elétrica para a operação do conjunto motobomba foi tomada junto ao painel do pivô, a partir dos componentes elétricos originalmente dispostos para a instalação de bombas injetoras.

\subsubsection{Reservatórios}

Armazenou-se a água utilizada nos ensaios em três reservatórios (caixas d'água) situados no centro do pivô. Dois desses reservatórios já se encontravam instalados no local, ambos sobre uma plataforma de alvenaria distante verticalmente $1,10 \mathrm{~m}$ da superfície do solo. O terceiro reservatório foi posicionado sobre a superfície do terreno. Dessa forma, esse último pôde ser abastecido, por meio de registros, a partir dos outros que se situavam em cota mais elevada. Toda a água fornecida ao sistema de pulverização foi recalcada a partir desse reservatório; os dois outros tiveram por finalidade apenas o armazenamento.

Embora a capacidade volumétrica individual de cada reservatórios seja de 500L, a quantidade de líquido disponível para o sistema de pulverização, contabilizando apenas os volumes úteis de cada reservatório, foi de aproximadamente 1200L.

$\mathrm{Na}$ torre central do pivô existia uma tomada de água com registro que, por meio de uma mangueira flexível, propiciou o enchimento de três reservatórios, quando necessário, durante as irrigações realizadas pelo pivô.

A água conduzida até os reservatórios provinha de uma represa abastecida por uma estação de bombeamento situada às margens do Rio Piracicaba. 


\subsubsection{Descrição geral do funcionamento do sistema hidráulico}

A água usada nos testes foi pressurizada no centro do pivô e conduzida até os inícios das terceira e quarta torres por meio da tubulação de distribuição. Nesses pontos, onde encontravam-se instaladas as válvulas reguladoras de pressão, o líquido passou a ser transportado por uma tubulação flexível até válvulas solenóides (tubulação de alimentação). Essas válvulas solenóides, posicionadas no início de cada uma das barras de pulverização, tiveram por função controlar o fluxo líquido para o interior das barras, sendo comandadas pelo circuito eletro-eletrônico.

As barras de pulverização mantiveram-se totalmente preenchidas graças à ação estanque das válvulas antigotas, possibilitando a operação dos emissores quase instantaneamente à abertura das válvulas solenóides.

\subsection{Componentes do sistema mecânico da barra de pulverização}

O sistema mecânico do equipamento de pulverização desenvolvido neste projeto visa à fixação da barra de pulverização e também permitir o controle de sua altura em relação ao alvo da aplicação. Foi composto dos conjuntos tensionador, de fixação e de controle de altura, cujos detalhes serão apresentados nos subtópicos a seguir.

Esclarece-se que todos os componentes da barra de pulverização foram fixados à estrutura do pivô por meio de parafusos e cabos de aço, sem causar qualquer tipo alteração ou danos ao mesmo.

\subsubsection{Conjunto tensionador}

Esse conjunto constou basicamente de um cabo de aço e acessórios, os quais tiveram por finalidade a sustentação da dupla barra de pulverização.

Utilizou-se um cabo de aço galvanizado, com diâmetro de 3mm (1/8”) (6 fios por perna, 7 pernas) e comprimento de 39m. Em ambas as extremidades foram aplicados esticadores, também galvanizados, com diâmetro nominal de 8mm (5/16”). Prendeu-se o 
cabo aos esticadores com grampos de $3 \mathrm{~mm}$ (1/8"). Um dos esticadores foi ligado a uma mola, e essa, por sua vez, foi presa ao parafuso central de um sistema móvel provido de rodas (rodízio) que compõem o conjunto de fixação descrito no item 3.6.2 . O segundo esticador foi conectado diretamente ao rodízio, que também faz parte do referido conjunto, porém, situado na outra torre de sustentação do vão em questão. As particularidades desses componentes podem ser vistos na Figura 9.

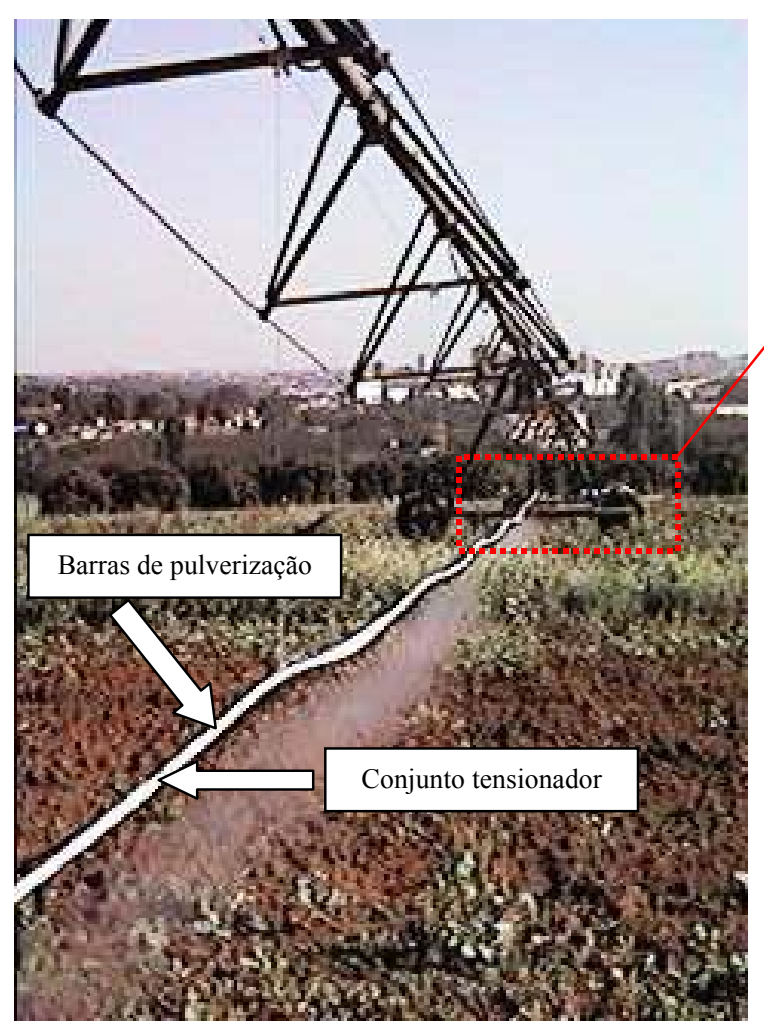

(a)

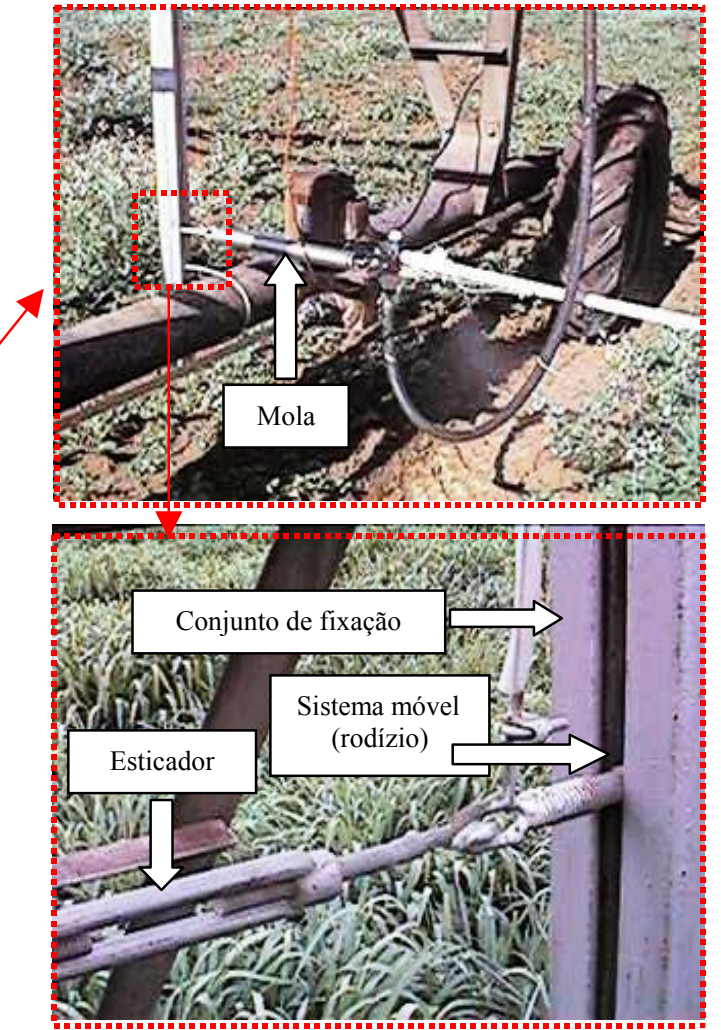

(b)

Figura 9 - Conjunto tensionador (a) e detalhes de sua ligação ao conjunto de fixação (b).

A aplicação dessa mola é fundamental no sentido de surtir o tensionamento do cabo de aço, além de compensar possíveis dilatações que esse possa sofrer em decorrência de variações térmicas.

Fixaram-se as barras de pulverização ao cabo de aço mediante abraçadeiras plásticas com largura de $5 \mathrm{~mm}$ e comprimento de $20 \mathrm{~cm}$. 


\subsubsection{Conjunto de fixação}

Esse componente teve por finalidade fixar todo o conjunto tensionador e foi montado sobre as torres de sustentação do lance do pivô onde se instalou o sistema de pulverização. O conjunto de fixação foi composto por duas estruturas idênticas, dispostas verticalmente sobre cada uma das referidas torres de sustentação. Cada conjunto foi formado por um perfil dobrado (trilho), sistema móvel com rodas (rodízio) e abraçadeira. Os perfis, estampados em chapa de aço-carbono (chapa preta 16), com comprimento de $3 \mathrm{~m}$, foram reforçados soldando duas cantoneiras de $25 \mathrm{x} 5 \mathrm{~mm}$ (1 x 3/16") externamente sobre ambas as pistas de rolamento dos rodízios. O objetivo desse reforço foi prover esses corpos de uma maior resistência à flambagem quando sujeitos a esforços perpendiculares à sua maior dimensão. Tanto o sistema móvel com rodas como o perfil são empregados usualmente na fabricação de portões metálicos do tipo "correr".

Prendeu-se a parte inferior dos perfis ao eixo principal da torre de sustentação, nas proximidades do motorredutor, por meio de uma abraçadeira confeccionada a partir de uma barra rosqueada com $8 \mathrm{~mm}\left(5 / 16^{\prime \prime}\right)$ de diâmetro. A parte superior foi fixada às cantoneiras que compõem a estrutura da torre de sustentação, empregando-se cabos de aço de $3 \mathrm{~mm}$ (1/8”) e grampos apropriados. Estes detalhes podem ser observados na Figura 10.

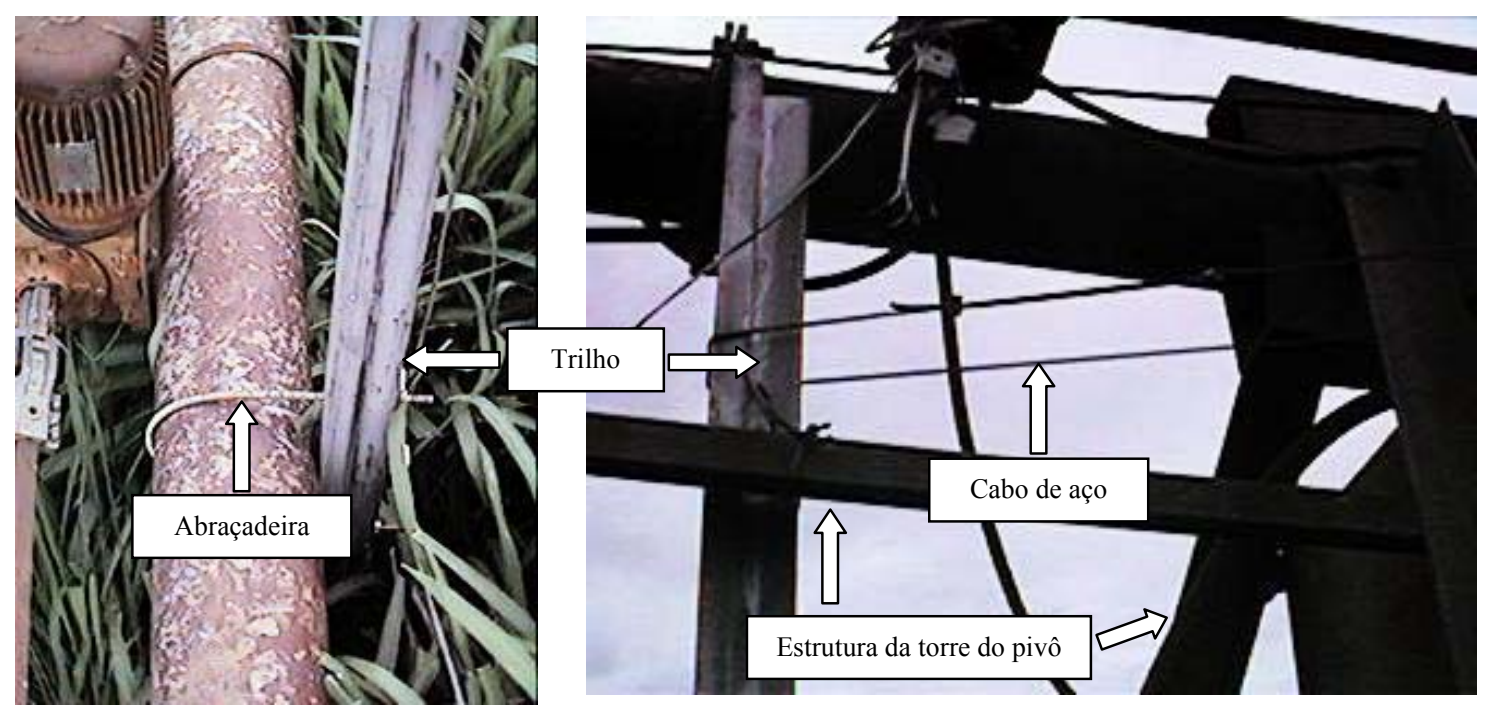

Figura 10 - Detalhes da ligação do conjunto de fixação à estrutura do pivô. 
No interior de cada perfil, dispôs-se um sistema móvel composto de quatro rolamentos "Stanley", com 38mm (11/2") de diâmetro, fabricados pela empresa brasileira Rodiflex. Esse sistema, como citado anteriormente, foi denominado rodízio. O centro geométrico do rodízio foi preso à estrutura que compõe a barra de sustentação por um parafuso. Na ponta desse parafuso, soldou-se uma argola para fixação dos componentes do conjunto tensionador (Figura 9b).

O deslocamento dos rodízios no interior dos perfis, após a completa montagem do conjunto de fixação, permitiu o movimento vertical das barras de pulverização.

\subsubsection{Conjunto de controle da altura de aplicação}

Esse componente consta basicamente de um conjunto formado por cabos de aço, roldanas e uma catraca, os quais movimentam verticalmente a barra de pulverização, permitindo o ajuste de sua altura em relação ao alvo pretendido.

A catraca utilizada é usualmente empregada na confecção de cercas de arame liso. Foi fixada por soldagem à uma base metálica com dimensões de 12 x $15 \mathrm{~cm}$ e presas a uma das cantoneiras da torre de sustentação. Uma das extremidades do eixo do tambor da catraca, no qual o cabo de aço é enrolado, recebeu uma manivela. Esses detalhes podem ser observados na Figura 11. 

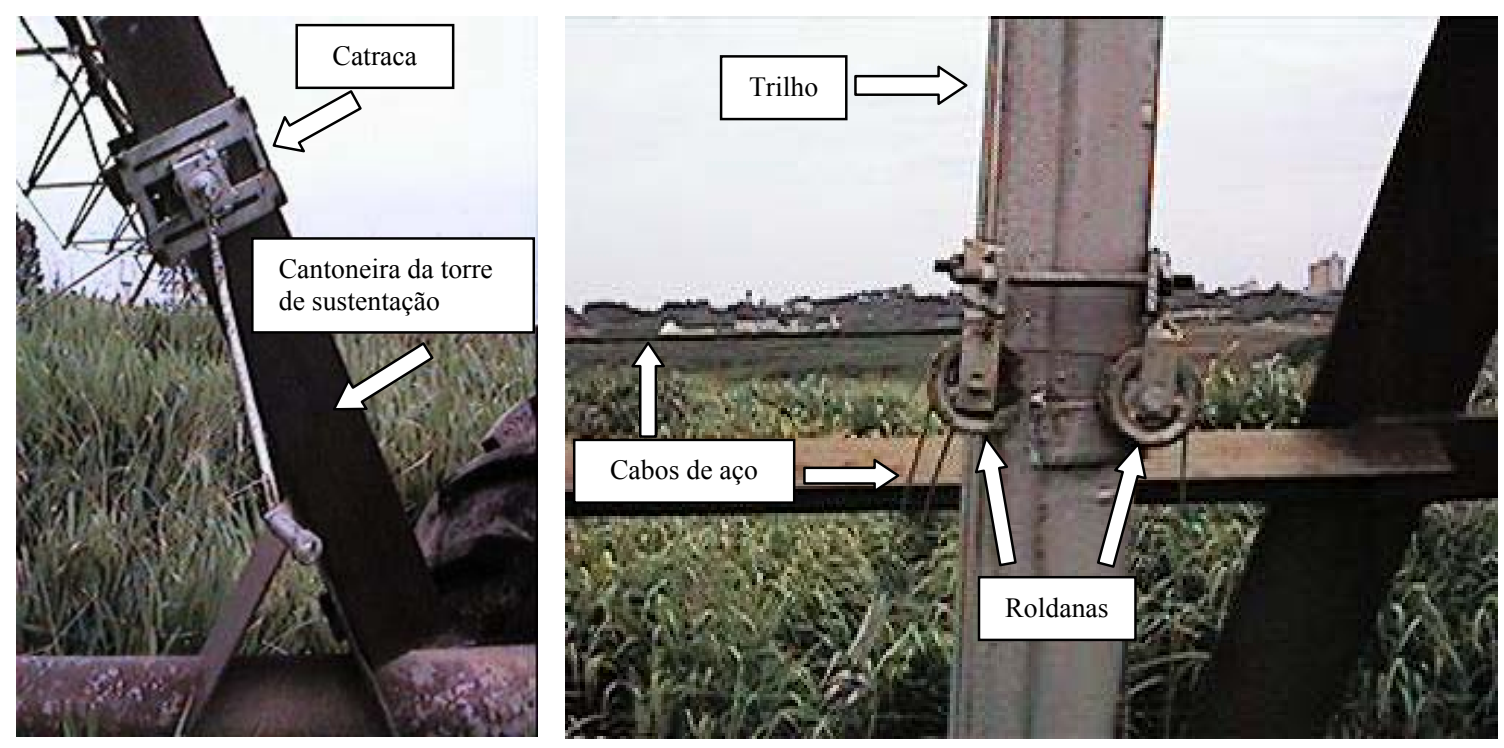

Figura 11 - Detalhes do conjunto de controle da altura de aplicação.

A partir da catraca e de carretilhas, posicionadas sob os triângulos que compõem a estrutura treliçada de sustentação da parte aérea do pivô, dispôs-se um cabo de aço ligando-as à extremidade oposta do conjunto tensionador, o qual recebeu a denominação cabo principal, cujos comprimento e diâmetro são $48 \mathrm{~m}$ e $6 \mathrm{~mm}$ (1/4"), respectivamente.

Objetivando reduzir a catenária do conjunto tensionador, prenderam-se segmentos de cabos de aço ao cabo principal, os quais, após a passagem pelas carretilhas instaladas lateralmente, foram presos a estruturas desenvolvidas para a fixação desses ao conjunto tensionador. Esses segmentos de cabos de aço, denominados secundários, apresentaram comprimento de $3 \mathrm{~m}$ e o mesmo diâmetro do cabo principal.

O conjunto tensionador foi ligado ao cabo principal em sete pontos distintos, sendo dois desses pontos nas extremidades da barra de pulverização e os demais distribuídos ao longo do conjunto tensionador, sob cada um dos triângulos estruturais do pivô.

As estruturas desenvolvidas para a fixação dos cabos ao conjunto tensionador foram formadas por duas cantoneiras com dimensões de 25 x $3 \mathrm{~mm}$ ( 1 x 1/8"), cada uma com comprimento de $10 \mathrm{~cm}$. Essas cantoneiras foram soldadas de maneira a formar uma peça única no formato " $\mathrm{T}$ ”. Nela fixaram-se duas argolas, as quais foram atravessadas 
pelo cabo de aço que compõe o conjunto tensionador. No centro da peça, fixou-se uma haste com diâmetro de $6 \mathrm{~mm}$ (1/4") e comprimento de $15 \mathrm{~cm}$. Na extremidade oposta da haste, instalou-se uma terceira argola, na qual prenderam-se as extremidades dos cabos de aço secundários. Realizaram-se todas essas ligações metálicas por soldagem. Essas estruturas foram concebidas, objetivando, além da ligação dos cabos secundários ao conjunto tensionador, reduzir a movimentação lateral do conjunto tensionador, principalmente nos momentos em que os motorredutores são acionados ou desligados. Os detalhes da montagem das carretilhas e da estrutura de fixação do cabo secundário podem ser observados na Figura 12.

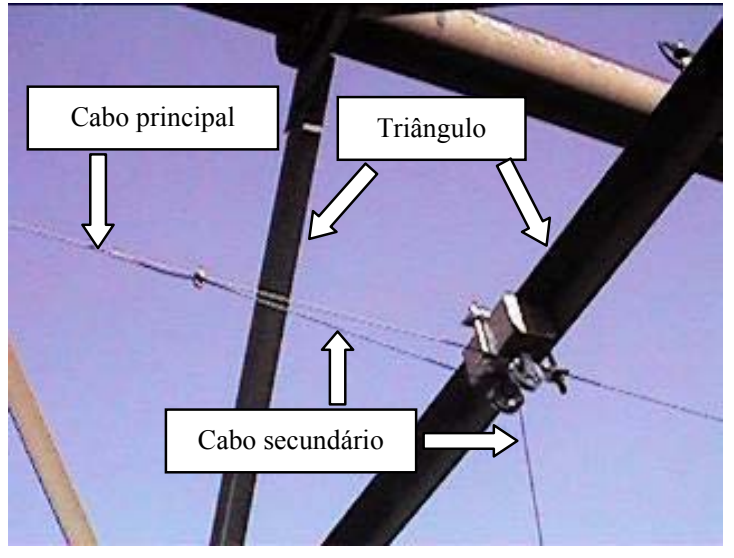

(a)

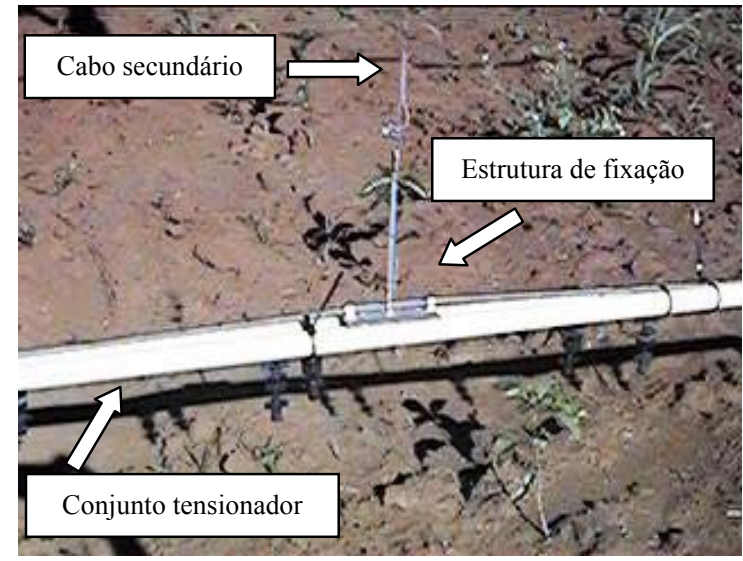

(b)

Figura 12 - Detalhes da fixação das carretilhas ao triângulo que compõe a parte aérea do pivô (a) e das estruturas desenvolvidas para fixação dos cabos de aço secundários ao conjunto tensionador (b).

\subsubsection{Descrição geral do funcionamento do sistema mecânico}

A movimentação da manivela, presa ao eixo da catraca, leva ao deslocamento do cabo principal. Esse cabo liga o tambor da catraca, a qual se encontra fixada em uma das torres de sustentação do vão do pivô, à extremidade do conjunto tensionador situada na outra torre de sustentação. 
Os seis cabos secundários estabelecem a ligação entre o cabo principal e outros pontos intermediários do conjunto tensionador, reduzindo a catenária desse.

Quando ocorre a movimentação do cabo principal, decorrente do manuseio da catraca, todos os pontos que estão ligados a esse cabo também se deslocam. O conjunto tensionador, no qual se encontram presas as barras de pulverização, passa então a ser movimentado verticalmente. Esse movimento ocorre por existirem rodízios nas extremidades do conjunto tensionador, que se deslocam no interior dos perfis metálicos que compõem o conjunto de sustentação. Dessa forma, quando a catraca é acionada em um determinado sentido, a barra é levantada. Quando movimentada no sentido oposto, é abaixada.

\subsection{Componentes do sistema eletro-eletrônico da barra de pulverização}

Obteve-se o reduzido volume de pulverização almejado neste trabalho mediante emprego de um circuito eletro-eletrônico, responsável pelo acionamento intermitente da válvula solenóide. Os detalhes do referido circuito são apresentados nos subtópicos a seguir.

\subsubsection{Fonte de energia}

A energia utilizada para alimentação do circuito eletro-eletrônico foi tomada junto às caixas elétricas do equipamento de irrigação.

Embora existam diferentes marcas e modelos de pivôs centrais, os circuitos elétricos empregados nesses equipamentos são relativamente semelhantes. Pelas caixas elétricas passam diversos condutores, transportando energia para alimentação de componentes ou estabelecer comandos elétricos. Dois desses condutores são responsáveis pela energização das bobinas dos contatores, os quais, por sua vez, acionam o conjunto motorredutor. Essa energia, aproveitada para alimentar todo o sistema eletro-eletrônico, é fornecida sob tensão próxima a $127 \mathrm{Vca}$, proveniente de um transformador rebaixador $440 / 127 \mathrm{Vca}$ disposto junto ao painel do pivô. Antes disso, 
porém, para que pudesse atender às características dos componentes do circuito eletrônico e às válvulas solenóides, a energia foi rebaixada, retificada e filtrada por meio de uma fonte de alimentação. A fonte empregada fornece uma tensão de $12 \mathrm{Vcc}$ e corrente máxima de $3 \mathrm{~A}$, suficiente para alimentar o circuito e a válvula solenóide.

Tanto a fonte de alimentação como o circuito eletrônico foram acondicionados no interior de uma caixa elétrica construída especificamente para essa finalidade. Essa caixa possuia uma estrutura presa a sua base, que permitiu fixá-la, por meio de parafusos, à mesma base da caixa elétrica do pivô central. A caixa foi confeccionada a partir de um segmento de tubo PVC para esgoto, com diâmetro de $150 \mathrm{~mm}$ e comprimento $30 \mathrm{~cm}$. Na borda superior, empregou-se um "cap" como tampa. Os aspectos construtivos e de instalação desse elemento podem ser vistos na Figura 13.

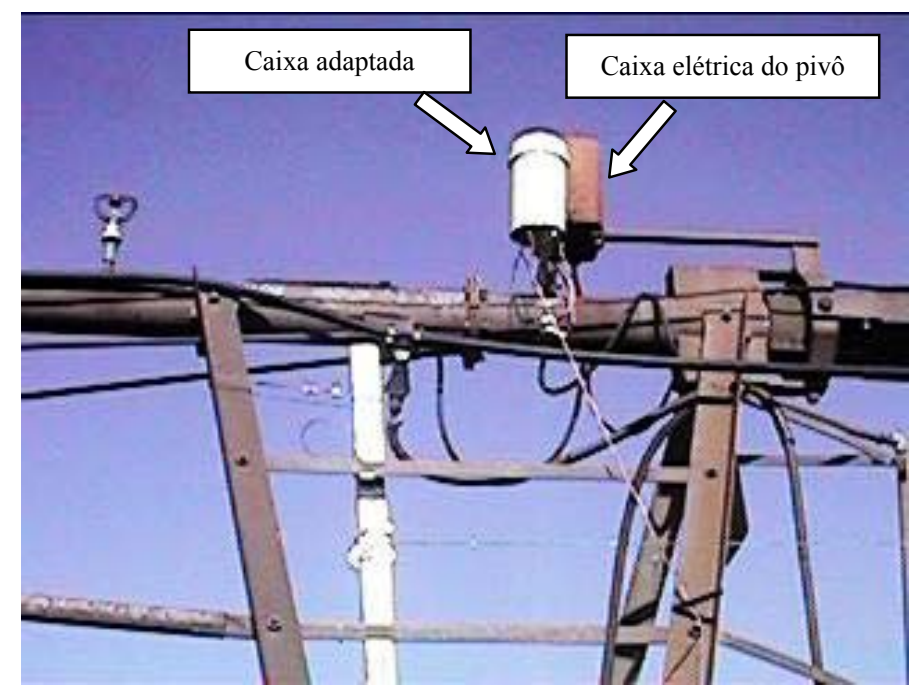

Figura 13 - Vista da caixa elétrica adaptada para abrigar os componentes eletroeletrônicos.

\subsubsection{Circuito eletro-eletrônico e microcontrolador}

Em razão da necessidade do sistema de pulverização operar de maneira intermitente, desenvolveu-se um circuito eletrônico no qual os tempos de operação dos 
motorredutores são contabilizados por um microcontrolador. Quando esses tempos atingem um determinado valor pré-definido na programação do microcontrolador, um sinal elétrico promove a abertura da válvula solenóide, por um intervalo de tempo também programado, obtendo-se a intermitência necessária à redução dos volumes de pulverização.

Esse circuito consta basicamente de um microcontrolador, dois relés e uma chave seletora, além de alguns resistores e capacitores. Todos esses componentes foram montados sobre uma placa de fenolite, de acordo com o diagrama de ligação apresentado na Figura 14. Um transformador rebaixador $127 \mathrm{~V} / 12 \mathrm{Vca}$ x $300 \mathrm{~mA}$ complementa os elementos requeridos para o funcionamento do circuito.

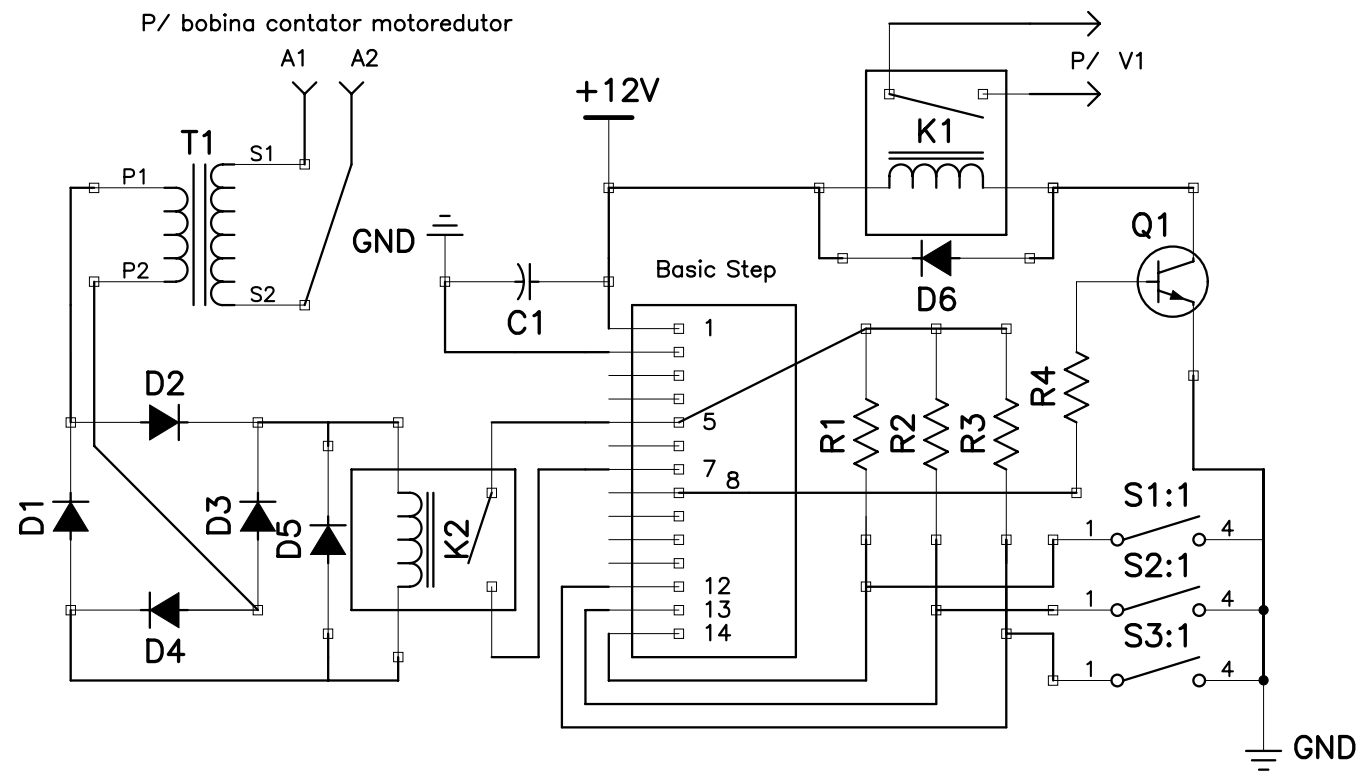
D1 a D6: diodo 1N4007
C1: capacitor $100 \mathrm{nF} / 25 \mathrm{~V}$
Q1: transistor BC548
T1: trafo $127 / 12 \mathrm{Vca} \times 300 \mathrm{~mA}$
$\mathrm{K} 1$ e K2: relé $12 \mathrm{Vcc} / 50 \mathrm{~mA}$
V1: válvula solenóide
R1 a R4: resistor $10 \mathrm{~K} \Omega$

Figura 14 - Esquema do circuito eletrônico microcontrolado.

Empregou-se o microcontrolador Basic Step, fabricado pela empresa nacional Tato Equipamentos Eletrônicos Ltda.. Esse modelo de microcontrolador, que deve ser alimentado com tensões entre 7,5 e $15 \mathrm{Vcc}$, possui oito pinos configuráveis como saídas ou entradas de sinais digitais. O equipamento também dispõe de um pino capaz de fornecer tensões reguladas de 5Vcc (pino 5). 


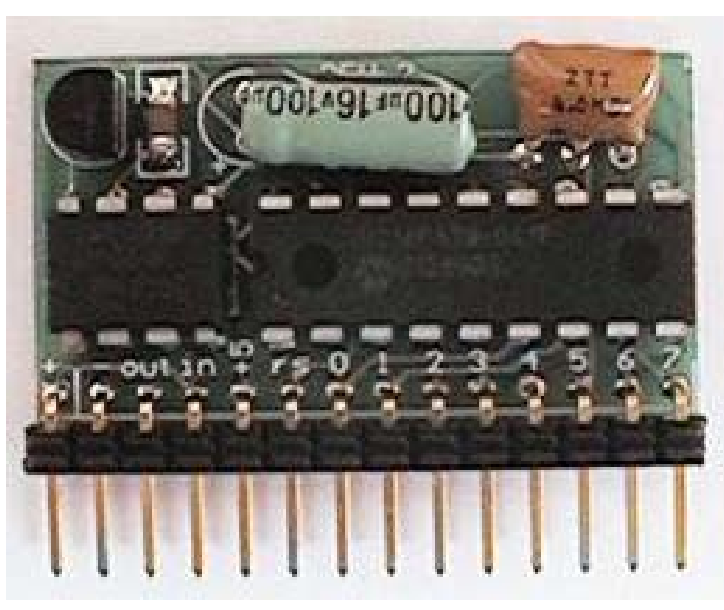

(a)

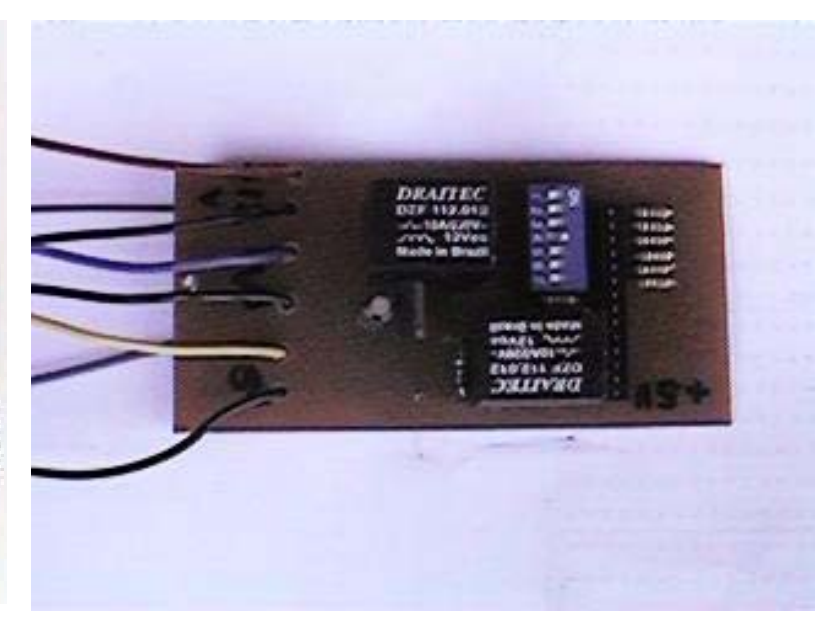

(b)

Figura 15 - Microcontrolador Basic Step (a) e aspecto final do circuito eletrônico desenvolvido (b).

A programação do microcontrolador foi feita por meio de uma linguagem denominada "tbasic", similar em diversos aspectos ao conhecido "basic", o que muito facilitou o desenvolvimento do programa. Essa programação foi realizada em um software emulador, disponibilizado gratuitamente pelo fabricante, instalado em um computador pessoal. Após sua conclusão, o programa foi enviado serialmente para o microcontrolador, sem a necessidade de gravadores especiais, permanecendo armazenado em sua memória, e executado toda vez que o microcontrolador foi acionado. Esclarece-se que todas essas vantagens e facilidades em muito contribuíram para a escolha do referido modelo de microcontrolador.

$\mathrm{O}$ programa desenvolvido para atender às necessidades da barra de pulverização encontra-se no Anexo B.

O circuito eletro-eletrônico operou da seguinte maneira: o transformador foi conectado aos mesmos terminais que alimentam a bobina do contator, responsável pelo acionamento dos motorredutores. Na saída do transformador, apresentando tensão de $12 \mathrm{Vca}$, elaborou-se uma ponte retificadora com diodos de uso geral (1N4007), cujo esquema de montagem também se encontra na Figura 14. As saídas dessa ponte, apresentando corrente em regime contínuo, foram ligadas à bobina do relé " K1". Dessa 
forma, quando ocorre a energização dos motorredutores, o relé "K1" fecha-se estabelecendo contato elétrico entre o pino de saída regulada $5 \mathrm{Vcc}$ do microcontrolador e o seu primeiro pino, configurado como entrada (pino 7). Quando esse pino encontra-se em nível alto $(5 \mathrm{Vcc})$, mediante ação do contato elétrico do relé, uma sub-rotina da programação do microcontrolador é ativada, operando como um contador de tempos. Quando o contato elétrico é interrompido, a programação do microcontrolador é desviada para uma outra sub-rotina e os tempos deixam de ser contabilizados. Isso permite, obviamente atendendo à programação, que o microcontrolador envie sinais elétricos intermitentes para a válvula solenóide somente quando o sistema de deslocamento do pivô é acionado. A intermitência da pulverização é então alcançada por outras sub-rotinas em que se estabelecem quais serão os tempos ligado e desligado da válvula solenóide. Essas sub-rotinas são também ativadas por sinais elétricos estabelecidos em outros pinos do microcontrolador (pinos 12, 13 e 14), decorrentes do posicionamento da chave seletora existente no circuito eletrônico. Assim, os tempos ligado e desligado das válvulas solenóides podem ser escolhidos de acordo com o posicionamento dos pinos da chave seletora, permitindo que a pulverização seja realizada sob três diferentes taxas de aplicação, obedecendo à programação estabelecida no microcontrolador. A energização da válvula solenóide ocorre indiretamente por meio do relé "K2" que, por sua vez, encontra-se ligado ao segundo pino do microcontrolador (pino 8). Incorporou-se um transistor entre esses dois elementos, operando como chave, com a finalidade de reduzir a corrente drenada do microcontrolador.

Todos os contatos elétricos ocorrem indiretamente por meio de relés e transformadores, dispensando aterrá-los junto ao pivô.

\subsection{Aspectos construtivos da barra de pulverização}

A barra de pulverização desenvolvida neste trabalho possui características peculiares que a difere de outros modelos conhecidos. A principal diferença que será abordada nos tópicos subseqüentes, indubitavelmente, é o sistema de barras duplas, no 
qual se pretende compensar as diferenças de velocidade que ocorrem ao longo do vão de cada torre constituinte do pivô.

\subsubsection{Variantes da velocidade de deslocamento ao longo do vão do pivô}

A movimentação de um pivô circular elétrico sobre área irrigada acontece sempre a partir de sinais dessa natureza, enviados do painel central para a última torre. Todas as demais torres possuem dispositivos que as mantêm alinhadas com o ponto do pivô e a última torre. Esse alinhamento é feito de maneira individualizada, em cada uma das torres, exceto na última torre de sustentação.

Ao se analisar minuciosamente e individualmente o deslocamento de qualquer um dos vãos intermediários que compõe um pivô central, pode-se identificar quatro diferentes possibilidades de ocorrência de movimento, a saber: i) o vão é movimentado por ação do sistema de propulsão instalado na torre de sustentação desse, que se encontra na extremidade mais próxima do centro do pivô; ii) o vão é movimentado por ação do sistema de propulsão instalado na torre de sustentação desse, que se encontra na extremidade mais distante do centro do pivô; iii) o vão é movimentado por ação de ambos os sistemas de propulsão, e $i v$ ) ausência de movimento de todo o vão pelo fato de os sistemas de propulsão não apresentarem movimento. Essas quatro variantes geram diferentes distribuições de velocidades ao longo do vão. Por exemplo, na primeira possibilidade de movimentação descrita, o ponto do vão que se encontra exatamente sobre a torre de sustentação mais próxima ao centro do pivô tem a mesma velocidade dessa. Os outros pontos apresentam suas velocidades gradualmente reduzidas, desde esse primeiro, em que é máxima, até a extremidade oposta do vão, em que não existe movimento. A segunda possibilidade de movimentação pode ser exemplificada exatamente como a primeira, porém, o ponto que apresenta velocidade nula encontrarse-á sobre a torre de sustentação mais próxima do centro do pivô, o de máxima velocidade, sobre a outra torre de sustentação. Na terceira situação, em razão do acionamento simultâneo dos dois sistemas de propulsão, todos os pontos do vão apresentam exatamente a mesma velocidade. A quarta e última situação corresponde ao 
oposto da situação anterior, na qual todos os pontos ao longo do vão possuem velocidade nula. As três primeiras situações podem ser observadas esquematicamente na Figura 16.

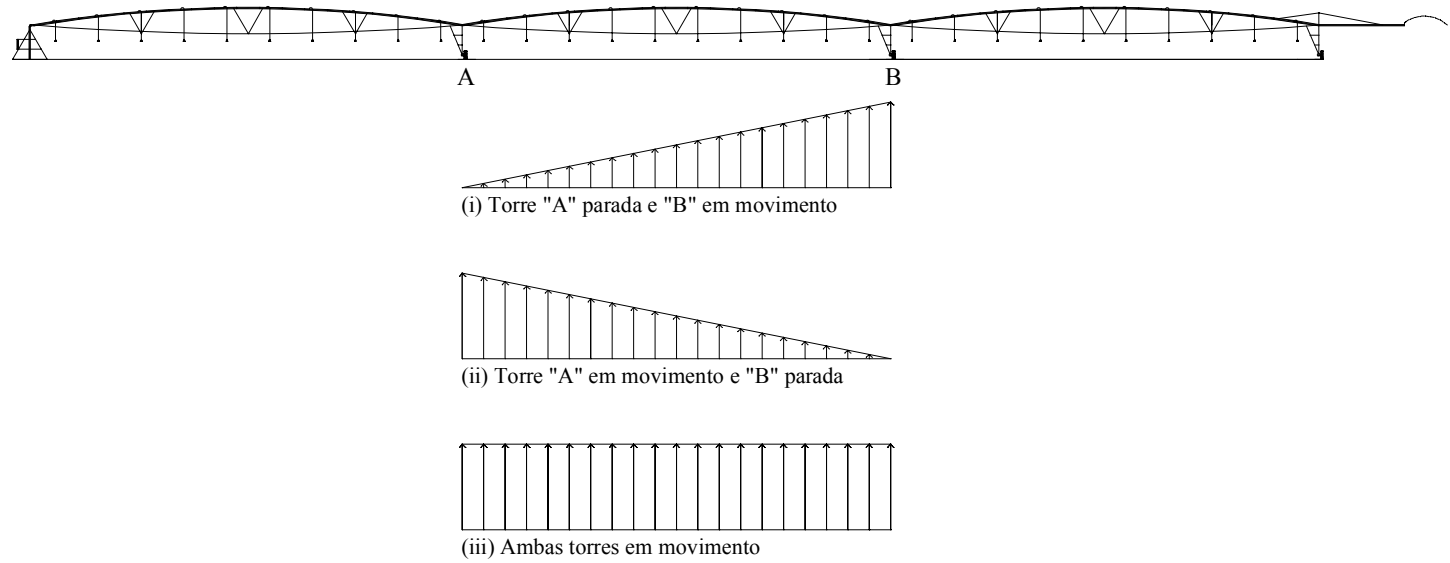

Figura 16 - Esquema ilustrativo das variantes de distribuições de velocidades (i, ii, iii) que podem ocorrer ao analisar um único vão de um pivô central.

\subsubsection{Comprimento e posicionamento das barras}

Em razão das variações de velocidade que ocorrem ao longo de um determinado vão do pivô, associadas aos diminutos diâmetros molhados apresentados pelos emissores empregados como elementos formadores de gotas, decidiu-se, nesse projeto, trabalhar com duas barras de pulverização por cada um dos vãos constituintes do sistema de irrigação. Acredita-se que com o emprego das duas barras, equipadas com bocais capazes de propiciar perfis do tipo cônico cheio, contemplariam-se as necessidades de sobreposição dos jatos líquidos, possibilitando uniformidades de distribuição aceitáveis para a área a ser pulverizada.

Da maneira como o projeto das barras de pulverização foi concebido, essas devem apresentar comprimento inferior ao do vão no qual serão instaladas. Isso se deve ao fato de que a posição do emissor situado mais distante na torre de sustentação em movimento, bem como sua vazão, espaçamento máximo e velocidade de deslocamento 
no ponto determinam o volume de pulverização do primeiro emissor e dos demais, o que será demonstrado por meio das equações apresentadas nos itens 3.8.4.2 e 3.8.4.3. Quanto maior o comprimento da barra de pulverização, maior também será o volume de pulverização aplicado.

O posicionamento das barras no vão do pivô ocorre de maneira contraposta. Uma das barras iniciou-se sobre uma determinada torre de sustentação, direcionando-se no sentido da outra torre. Nessa posição, ocorreu sua alimentação, controlada por uma válvula solenóide. A segunda barra foi instalada da mesma forma que a primeira, porém, iniciando-se sobre a torre de sustentação oposta. Assim, quando os comprimentos da barras correspondem a exatamente $80 \%$ do vão do pivô, $60 \%$ desse comprimento, no centro do vão, encontram-se sob ação das duas barras de pulverização. As extremidades do vão, que correspondem juntas a 40\% do comprimento desse, recebem aplicações provenientes apenas de uma das barras de pulverização.

$\mathrm{Na}$ Figura 17 é apresentado um esquema de como ficaria todo o sistema de pulverização instalado em um pivô composto de quatro torres e tubulação em balanço.

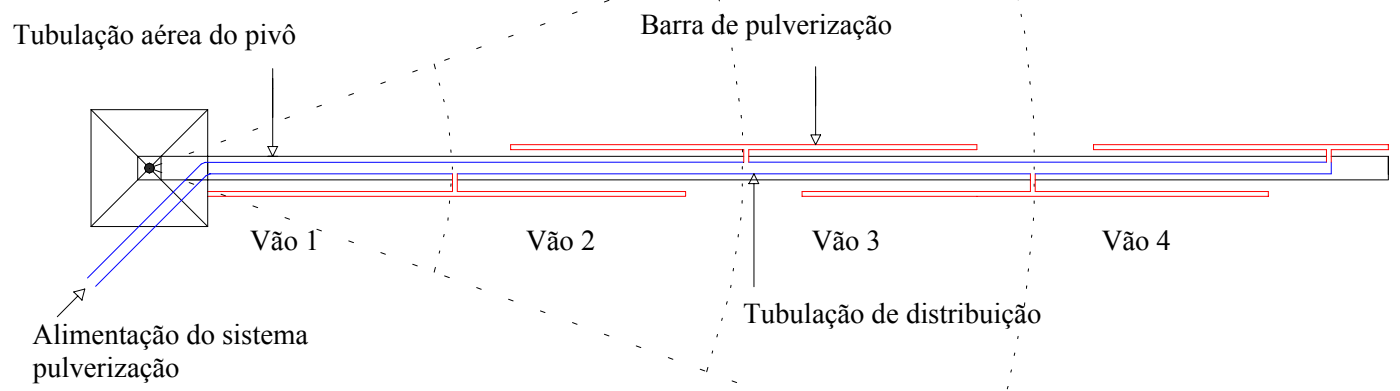

Figura 17 - Esquema de posicionamento das barras de pulverização em um pivô central. 
Por razões de dificuldades de ordem técnica e prática, o sistema de pulverização desenvolvido neste trabalho não contempla aplicações em áreas periféricas cobertas por canhões hidráulicos.

\subsubsection{Cálculo da largura máxima da faixa de deposição dos emissores}

A largura máxima da faixa de deposição de cada modelo de bocal depende tanto do perfil de distribuição de água desses como da sobreposição desejada, o que particularmente influencia a uniformidade da aplicação.

Aparentemente parece não existir um padrão de uniformidade que dê suporte à avaliação da uniformidade de distribuição em situações em que os coletores são distribuídos espacialmente na área pulverizada. Entretanto, nas pulverizações terrestres, os ensaios de uniformidade realizados sobre mesas de distribuição são mundialmente aceitos, empregando-se o CV para expressar o grau de variação da distribuição.

Para a determinação da máxima largura da faixa de deposição, realizaram-se simulações nas quais buscou-se transformar os resultados de distribuições espaciais em lineares. Assim, os resultados obtidos puderam ser analisados de maneira semelhante aos verificados em mesas de distribuição, inclusive utilizando-se o CV como parâmetro de análise.

As simulações dos quatro modelos de bocais partiram dos perfis de distribuição de água estabelecidos previamente. Todas essas simulações foram feitas em uma planilha eletrônica.

Inicialmente desenvolveu-se uma planilha cujas células foram preenchidas com valores correspondentes às distâncias radiais dessas a um ponto de origem. Esse ponto de origem estaria, então, representando a posição do emissor, localizado no centro de uma malha quadrada. As células, da maneira como a planilha foi idealizada, estavam distanciadas vertical e horizontalmente de $1 \mathrm{~cm}$. As distâncias radiais das células ao ponto representativo da posição do emissor foram calculadas por meio das relações trigonométricas. 
A partir dessa primeira planilha, gerou-se uma segunda, em que os valores das distâncias radiais foram substituídos, por meio das equações geradas para cada um dos perfis de distribuição de água, pelas intensidades de precipitação produzidas pelo emissor em cada um desses pontos. Como exemplo, o Apêndice 2 traz alguns valores de distâncias e lâminas calculadas para alguns pontos próximos ao emissor.

Considerando-se esses cálculos, tomou-se o somatório dos valores de cada uma das colunas. Esse somatório foi usado para simular sobreposições provenientes de diferentes espaçamentos de emissores.

Os alcances para cada um dos modelos de bocais foram considerados como as distâncias máximas a partir dos emissores, dentro do intervalo esperado para suas ocorrências, imediatamente anteriores as que proporcionavam raízes positivas nulas ou negativas nas equações utilizadas para caracterizar os perfis médios de precipitação. Para isso, desenvolveram-se testes condicionais nas planilhas eletrônicas empregadas para as simulações em que células contendo tais raízes foram automaticamente substituídas por zero.

Nas referidas simulações, os espaçamentos entre emissores foram variados a cada $1 \mathrm{~cm}$, estabelecendo-se que a largura máxima da faixa de deposição dos emissores, que nesse caso coincidiu com o espaçamento por se tratar de emissores semelhantes, seria aquela que permitisse, após as simulações e considerando as sobreposições dos perfis, obter valores de $\mathrm{CV}$ entre dois emissores consecutivos e idênticos inferiores ou iguais a $10 \%$.

\subsubsection{Determinação do posicionamento dos emissores na barra de pulverização}

Os emissores foram instalados na barra de maneira a atender as variações de velocidade que ocorrem ao longo do vão do pivô. Dessa forma, todos os pontos sob a barra de pulverização deveriam receber, teoricamente, o mesmo volume de pulverização por unidade de área tratada.

$\mathrm{Na}$ seqüência será abordada a metodologia para dimensionamento das barras de pulverização de um determinado vão do pivô. Vãos que apresentem a mesma velocidade 
de deslocamento e comprimento devem ser equipados com barras de pulverização idênticas. Caso contrário, cada vão diferenciado deve receber barras distintas, mas capazes de aplicar exatamente a mesma calda.

\subsubsection{Localização do primeiro emissor}

Nos testes preliminares realizados com a barra de pulverização, percebeu-se, inicialmente, de maneira intuitiva, que a válvula solenóide poderia operar com uma relação de tempos ligado/desligado de 1:9s, o que teoricamente proporcionaria redução a 10\% da quantidade a ser aplicada sem intermitência. Assim, a escolha da posição do primeiro emissor a $29,9 \mathrm{~m}$ de distância da torre a se considerar o movimento, o que corresponde a aproximadamente $80 \%$ do comprimento total do vão, resultaria em volumes de aplicação próximos a 3.700L/ha, o que corresponderia a 370L/ha, quando considerada a intermitência devida à relação de tempos citada, alcançando um dos objetivos desse trabalho.

\subsubsection{Cálculo do volume de pulverização do primeiro emissor}

$\mathrm{Na}$ seqüência serão abordadas equações que fazem parte do desenvolvimento matemático para obtenção da equação empregada para o cálculo do volume de pulverização do primeiro emissor. Algumas das variáveis utilizadas no referido desenvolvimento podem ser observadas, esquematicamente, na Figura 18. 


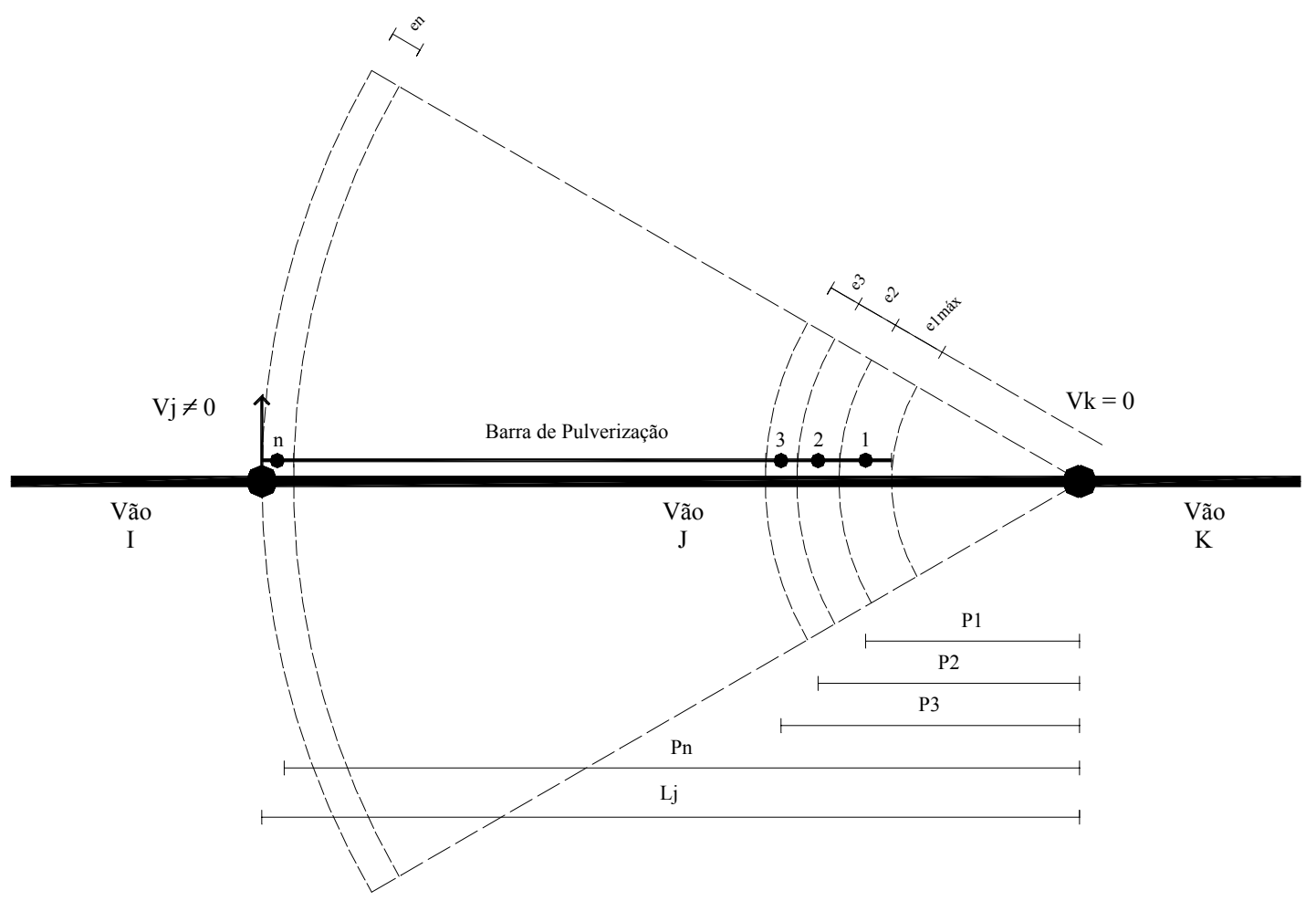

Figura 18 - Esquema ilustrativo das variáveis utilizadas no dimensionamento de uma barra de pulverização alimentada pela extremidade disposta entre os vãos I e K de um pivô central.

A intensidade de precipitação proporcionada pelo primeiro emissor é fornecida pela seguinte expressão:

$$
\text { Ip }=\frac{q_{1}}{A_{1}}
$$

em que $\operatorname{Ip}(\mathrm{mm} / \mathrm{h})$ é a intensidade de precipitação do emissor; $q_{1}(\mathrm{~L} / \mathrm{h})$ a vazão do primeiro emissor e; $A_{l}\left(\mathrm{~m}^{2}\right)$ a área coberta pelo primeiro emissor. 
A lâmina aplicada por esse emissor pode ser determinada considerando, na eq.(3), o tempo requerido para um determinado vão efetuar uma revolução em torno de si mesmo:

$$
\operatorname{Lam}_{1}=\frac{q_{1}}{A_{1}} \cdot \operatorname{Tr}
$$

em que $\operatorname{Lam}_{1}(\mathrm{~mm})$ é a lâmina aplicada pelo primeiro emissor e, $\operatorname{Tr}(\mathrm{h})$, o tempo de revolução.

O tempo de revolução é dado por:

$$
\operatorname{Tr}=\frac{2 \cdot \pi \cdot L_{j}}{V_{j}}
$$

em que $\pi$ (adimensional) é a razão entre o perímetro e o diâmetro de uma circunferência; $L_{j}(\mathrm{~m})$, o comprimento do j-ésimo vão no qual instalar-se-á a barra de pulverização e, $V_{j}$ $(\mathrm{m} / \mathrm{h})$, a velocidade de deslocamento do sistema de propulsão da j-ésima torre.

Substituindo a eq. (5) na eq. (4), temos:

$$
\operatorname{Lam}_{1}=\frac{2 \cdot \pi \cdot q_{1} \cdot L_{j}}{A_{1} \cdot V_{j}}
$$

Para efeito de dimensionamento, supondo uma volta completa em torno do ponto em que a torre está parada, a área coberta pelo primeiro emissor pode ser determinada pela expressão: 


$$
A_{1}=\pi \cdot\left[\left(P_{1}+\frac{e_{1 \max }}{2}\right)^{2}-\left(P_{1}-\frac{e_{1 \max x}}{2}\right)^{2}\right]
$$

em que $P_{l}(\mathrm{~m})$ é a posição do emissor a partir do lado oposto da alimentação da barra e; $e_{1 \text { máx }}(\mathrm{m})$ a largura máxima da faixa de deposição do primeiro emissor.

A eq. (7) pode ser reescrita da seguinte maneira:

$$
A_{1}=2 \cdot \pi \cdot P_{1} \cdot e_{1 \operatorname{máx}}
$$

Substituindo a eq.(8) na eq.(6), a lâmina aplicada pelo primeiro emissor passa a ser determinada pela seguinte expressão:

$$
\operatorname{Lâm}_{1}=\frac{q_{1} \cdot L_{j}}{P_{1} \cdot e_{1 \text { máx }} \cdot V_{j}}
$$

Considerando que a vazão do emissor pode ser expressa por uma equação potencial explicitada na eq. (1), pode-se reescrever a equação anterior:

$$
\operatorname{Lâm}_{1}=\frac{K_{1} \cdot H^{x_{1}} \cdot L_{j}}{P_{1} \cdot e_{1 \text { máx }} \cdot V_{j}}
$$

Para se obter a calda (L/ha) aplicada pelo primeiro emissor, basta multiplicar a eq.(10) pelo número de metros quadrados contidos em um hectare:

$$
C_{1}=\frac{K_{1} \cdot H^{x_{1}} \cdot L_{j} \cdot 10.000}{P_{1} \cdot e_{1 \text { máx }} \cdot V_{j}}
$$

em que $C_{1}(\mathrm{~L} / \mathrm{ha})$ é a calda aplicada pelo primeiro emissor. 


\subsubsection{Cálculo do espaçamento entre emissores}

O cálculo do espaçamento entre os demais emissores parte do princípio de que todos os pontos da área circular devam receber exatamente a mesma lâmina. Para que isso ocorra, todos os pontos cobertos por um mesmo modelo de emissor devem apresentar a mesma área tratada.

A área tratada pelo primeiro emissor é definida na eq. (8). O segundo emissor, quando semelhante ao primeiro, deve ser posicionado a uma maior distância do que este em relação à torre que se espera estar parada. Por esse motivo e em razão da necessidade das áreas tratadas pelos mesmos serem de tamanhos idênticos, a largura da coroa circular coberta pelo segundo emissor deve ser menor do que a do primeiro. Da mesma forma, o cálculo do espaçamento entre os demais emissores acompanha o mesmo raciocínio, tornando-se os espaçamentos cada vez menores. Existindo a possibilidade de utilização de outros modelos de bocais, o de menor tamanho deve ser substituído por outro de diâmetro imediatamente superior nos pontos onde seja possível manter a mesma lâmina sob o espaçamento máximo dos bocais de maior abertura.

A posição de instalação de um determinado bocal, tomando-se como base o posicionamento na barra de pulverização do seu antecessor, pode ser obtida pela seguinte expressão geral:

$$
P_{i}=P_{i-1}+\frac{e_{i-1}}{2}+\frac{e_{i}}{2}
$$

em que $P_{i}(\mathrm{~m})$ é o posicionamento do i-ésimo emissor ao longo do vão e; $e_{i}(\mathrm{~m})$ a largura da faixa de deposição do i-ésimo emissor.

Substituindo a eq. (12) na eq. (10) e reescrevendo na forma geral, tem-se: 


$$
\operatorname{Lam}_{1}=\frac{K_{i} \cdot H^{x_{i}} \cdot L_{j}}{\left(P_{i-1}+\frac{e_{i-1}}{2}+\frac{e_{i}}{2}\right) \cdot e_{i} \cdot V_{j}}
$$

que pode ser tomada na forma de um polinômio de segundo grau:

$$
\frac{e_{i}^{2}}{2}+\left[\left(P_{(i-1)}+\frac{e_{(i-1)}}{2}\right) \cdot e_{i}\right]-\left(\frac{K_{i} \cdot H^{x_{i}} \cdot L_{j}}{L \hat{a} m_{1} \cdot V_{j}}\right)=0
$$

A raiz positiva da eq. (14) explicita o valor da largura da faixa de deposição para o i-ésimo emissor situado no primeiro vão ou em vãos intermediários.

$$
e_{i}=\sqrt{\left(P_{(i-1)}+\frac{e_{(i-1)}}{2}\right)^{2}+2 \cdot\left(\frac{K_{i} \cdot H^{x_{i}} \cdot L_{j}}{L a m_{1} \cdot V_{j}}\right)}+\left(P_{(i-1)}+\frac{e_{(i-1)}}{2}\right)
$$

Conhecendo-se a largura da faixa de deposição de cada emissor, suas posições ao longo da barra de pulverização do primeiro vão ou vãos intermediários podem ser determinadas por meio da eq. (12).

No caso do vão em balanço sugere-se que o dimensionamento seja realizado no sentido de sua extremidade para a última torre, buscando-se locar o último emissor da barra de pulverização no ponto mais distante do centro do pivô, daí . Dessa forma, temse:

$$
e_{i}=\left(P_{(i-1)}+\frac{e_{(i-1)}}{2}\right)-\sqrt{\left(P_{(i-1)}+\frac{e_{(i-1)}}{2}\right)^{2}-2 \cdot\left(\frac{K_{i} \cdot H^{x_{i}} \cdot L_{j}}{L a m_{1} \cdot V_{j}}\right)}
$$

Para essa situação, a posição dos emissores deve ser determinada pela expressão:

$$
P_{i}=P_{i-1}+\frac{e_{i-1}}{2}+\frac{e_{i}}{2}
$$




\subsubsection{Estimativa da perda de carga na barra de pulverização}

As estimativas das perdas de carga lineares de todas as canalizações que compõem o sistema de pulverização foram realizadas por meio da equação de DarcyWeisbach, apresentada por Azevedo Neto \& Alvarez (1977):

$$
h f=f \cdot \frac{L^{\prime}}{D} \cdot \frac{V^{2}}{2 g}
$$

em que $h f(\mathrm{~m})$ é a perda de carga no trecho considerado; $f$ (adimensional) o fator de atrito; $L^{\prime}(\mathrm{m})$ o comprimento total da tubulação no trecho considerado; $D(\mathrm{~m})$ o diâmetro interno da tubulação; $V(\mathrm{~m} / \mathrm{s})$ a velocidade de escoamento do fluído e; $g\left(\mathrm{~m}^{2} / \mathrm{s}\right)$ a aceleração da gravidade no local .

$\mathrm{O}$ valor do fator de atrito " $\mathrm{f}$ " foi determinado empregando-se a equação de Churchill (1977) que, segundo o autor, pode ser aplicada a qualquer regime de escoamento e todas as condições de rugosidade hidráulica:

$$
f=8 \cdot\left\{\left[\frac{8}{N r}\right]^{12}+\left[\frac{1}{(A+B)^{3 / 2}}\right]\right\}^{1 / 12}
$$

em que $N r$ (adimensional) é o número de Reynolds.

De acordo com o autor, o número de Reynolds para a água à temperatura de $20^{\circ} \mathrm{C}$ e os parâmetros " $\mathrm{A}$ ” (adimensional) e "B" (adimensional) que compõem a equação são obtidos pelas expressões abaixo:

$$
N r=1.260 .630 \cdot \frac{Q}{D}
$$




$$
\begin{gathered}
A=\left\{2,457 \cdot \ln \left[\frac{1}{\left(\frac{7}{N r}\right)^{0,9}+\left(\frac{0,27 \cdot k}{D}\right)}\right]\right\}^{16} \\
B=\left(\frac{34.530}{N r}\right)^{16}
\end{gathered}
$$

em que $Q\left(\mathrm{~m}^{3} / \mathrm{s}\right)$ é a vazão transportada e; $k(\mathrm{~m})$ a rugosidade absoluta da tubulação.

Considerou-se o valor de $0,015 \mathrm{~mm}$ para a rugosidade absoluta, de acordo com Melo Porto (1998).

Estimou-se a perda de carga ao longo da barra de pulverização considerando a vazão individual de cada um dos trechos que a compõe.

As perdas de carga localizadas, decorrentes das saídas para os emissores, foram determinadas com base no método dos comprimentos equivalentes. Segundo Pizarro Cabello (1987), no caso de inserções inferiores a 3,8 e 5mm de largura e comprimento, respectivamente, o comprimento equivalente pode ser determinado pela expressão:

$$
L_{e}=14,38 \cdot\left(D \cdot 10^{3}\right)^{-1,89}
$$

em que $L_{e}(\mathrm{~m})$ é comprimento equivalente ou virtual.

Considerando o diâmetro interno da tubulação empregada na barra de pulverização de $20,7 \mathrm{~mm}$, obteve-se o comprimento equivalente de $4,68 \mathrm{~cm}$ para cada uma das saídas para os emissores. A soma desse comprimento virtual $\left(L_{e}\right)$ à distância entre dois emissores consecutivos $(L)$ resultou no comprimento total (L'), o qual foi empregado na estimativa da perda de carga total entre os dois emissores considerados (eq. 18). 


\subsection{Metodologia para avaliação do equipamento}

Foram realizadas duas avaliações distintas do equipamento de pulverização após sua instalação no pivô central. Na primeira, buscou-se verificar se o espectro de gotas produzido ao longo da barra atendia aos requisitos recomendados à pulverização. $\mathrm{Na}$ segunda avaliação, foram realizados ensaios com objetivo de verificar a uniformidade de aplicação do equipamento desenvolvido. A barra de pulverização foi mantida a $50 \mathrm{~cm}$ da superfície do solo em todas as avaliações.

\subsubsection{Tamanho de gotas}

O tamanho das gotas produzidas pela barra de pulverização foi avaliado mediante a técnica de papéis hidrosensíveis. Empregaram-se cartões medindo 26 x 76mm fabricados pela empresa suíça Ciba-Geigy (atual Syngenta), os quais são distribuídos no Brasil pela Spray Systems Co..

Os cartões foram expostos à pulverização apenas por uma fração do tempo de aplicação, em razão de os volumes aplicados superarem o limite máximo de calda recomendado para o emprego desses. O controle da exposição realizou-se por meio de uma proteção sobre os cartões, a qual foi retirada no momento da amostragem. O tempo de exposição dos cartões à pulverização foi controlado de maneira que apenas um pequeno número de gotas sensibiliza- os. Os resultados das análises provenientes dos cartões prestaram-se exclusivamente para avaliação dos tamanhos de gotas.

Dispuseram-se os papéis diretamente sobre a superfície do solo, formando três linhas distanciadas de $1 \mathrm{~m}$ entre si e perpendiculares à direção de deslocamento da barra de pulverização (L1, L2 e L3). Cada uma das linhas foi composta de 5 cartões, perfazendo um total de 15 coletores que, foram posteriormente avaliados. O esquema da disposição dos coletores no campo pode ser observado na Figura 19. 


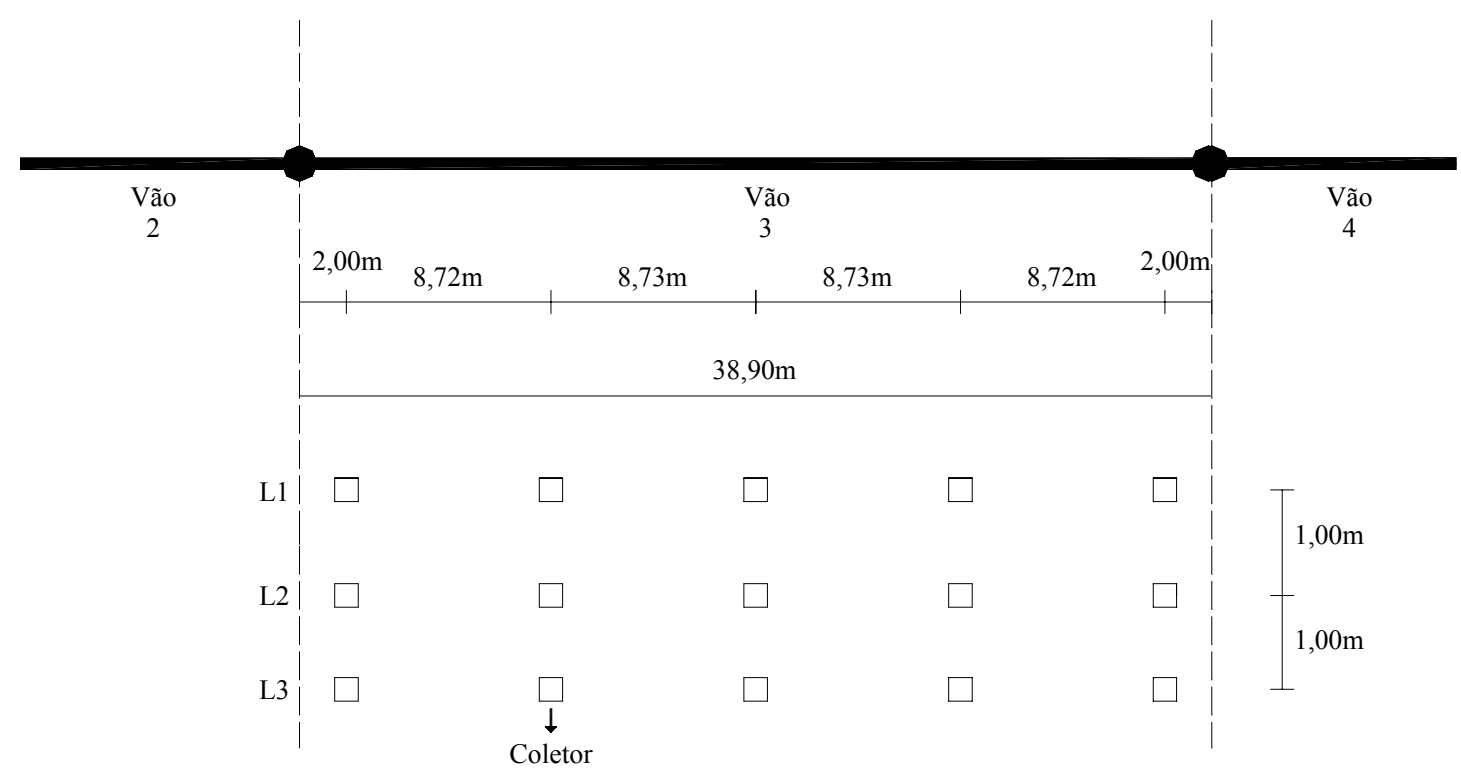

Figura 19 - Esquema de distribuição dos coletores sob a barra de pulverização.

Imediatamente após a distribuição dos coletores no campo, operou-se o pivô central com a máxima velocidade de deslocamento, de maneira a realizar pulverização sobre os papéis coletores. Terminada a aplicação, aguardaram-se 30min. Em seguida foram recolhidos todos os cartões, os quais foram acondicionados em recipientes hermeticamente fechados e conduzidos para pesagem no laboratório.

As análises das imagens dos cartões sensibilizados foram efetuadas por meio do software E-Sprinkle 1.1 (licenciado para o Departamento de Engenharia Rural da ESALQ/USP), comercializado pela Ablevision Sistemas Computacionais Ltda. Para cada cartão, determinaram-se o diâmetro mediano volumétrico (DMV), o diâmetro mediano numérico (DMN) e o coeficiente de dispersão (r), os quais foram empregados com intuito de caracterizar os espectros de gotas depositadas em cada uma das posições avaliadas.

A captura das imagens dos cartões deu-se em um scanner colorido, fabricado pela TCE Indústria Eletrônica da Amazônia Ltda., modelo S440, com resolução de 600dpi. Todo esse processo foi gerenciado pelo programa computacional Drop-Cap, fornecido juntamente com o software empregado para análises das imagens obtidas. 


\subsubsection{Uniformidade de aplicação}

A avaliação da uniformidade de aplicação foi feita empregando-se papéis absorventes como superfícies coletoras. Os papéis utilizados foram do tipo Filtro "L", com resistência úmido, gramatura de $80 \mathrm{~g} / \mathrm{m}^{2}$, produzidos pela empresa nacional Klabin Fabricadora de Papéis S.A.. Objetivando regularizar o tamanho da superfície coletora, os papéis foram cortados em guilhotina mecânica, apresentando todos eles dimensões exatas de $20 \times 20 \mathrm{~cm}$.

Antes, porém, de serem levados ao campo, os papéis devidamente cortados foram hermeticamente acondicionados em embalagens plásticas usadas para congelamento de alimentos. Utilizaram-se embalagens modelo Ziploc, com dimensões de $18 \times 20 \mathrm{~cm}$, fabricadas pela Johnson ${ }^{\circledR}$.

Após a inserção dos papéis no interior das referidas embalagens e o lacre do fecho vedador dessas, pesou-se todo o conjunto formado por esses dois elementos em balança eletrônica com precisão de $0,01 \mathrm{~g}$. O resultado dessa pesagem denominou-se massa seca e todos os conjuntos foram devidamente marcados.

Preparados 15 conjuntos, os quais seriam suficientes para uma análise de campo, todos foram acondicionados para transporte dentro de uma caixa de isopor com capacidade de $17 \mathrm{~L}$.

A distribuição dos papéis no campo deu-se exatamente nas mesmas posições onde foram avaliados os tamanhos de gotas (Figura 19). Com propósito de evitar o contato direto dos papéis com a superfície do solo, colocou-se sob esses uma superfície de madeira revestida com fórmica, apresentando dimensões de $25 \times 25 \mathrm{~cm}$.

Terminada a distribuição dos papéis no campo, o sistema de pulverização foi prontamente acionado. Imediatamente após a aplicação, os papéis foram rapidamente introduzidos nas respectivas embalagens, reacomodados na caixa de isopor $\mathrm{e}$ transportados para o laboratório no menor espaço de tempo possível. No laboratório, cada conjunto foi novamente pesado, obtendo-se a chamada massa úmida.

Considerando a densidade da água igual à unidade, a diferença entre a massa úmida e a massa seca dos conjuntos resultou no volume recebido por cada um dos papéis 
nos respectivos pontos amostrados. Obteve-se a calda (L/ha) relacionando-se esse volume à área de cada papel.

Avaliaram-se resultados provenientes de nove possíveis combinações de tempos ligados de 0,3, 0,4 e 0,5s e desligados de 2,5, 3,0 e 3,5s.

\subsection{Programa computacional}

O programa computacional para dimensionamento das barras de pulverização de um determinado vão do pivô central, denominado Sistema de Pulverização para Pivô Central (SPPC), cujo fluxograma é apresentado no Anexo C, foi desenvolvido em linguagem de programação Visual Basic, vs. 5.0 (Serial Number 5674408081511625348 98).

Os dados de entrada do programa são: comprimento do vão, distância do primeiro emissor à torre que se encontra supostamente parada para efeito de dimensionamento, velocidade de deslocamento do sistema de propulsão, distância de recuo do primeiro emissor em relação ao plano vertical que passa pelo centro geométrico das rodas, tempos que a válvula solenóide deve permanecer ligada e desligada, diâmetro interno da tubulação da barra, pressão de operação do último emissor, coeficiente de ajuste da equação do emissor e seu expoente característico, largura máxima da faixa de deposição de cada modelo de emissor e cor do bocal.

Com essas informações, o programa calcula a lâmina a ser aplicada pelo primeiro emissor, que deve ser mantida para os demais. Baseando-se nesse cálculo, define-se a largura da faixa de deposição do segundo emissor, que é feita de maneira interativa em virtude de que essa distância influencia diretamente na perda de carga e, conseqüentemente, na vazão do emissor e na largura de sua faixa de deposição, para que a calda a ser aplicada por esse seja mantida constante em toda extensão da barra. Os demais emissores são dimensionados de maneira semelhante. As substituições dos emissores de menor vazão pelos de maior, ao longo barra de pulverização, são feitas nas posições em que a largura da faixa de deposição do emissor subseqüente passa a ser imediatamente inferior à máxima recomendada para esse emissor. 
Os resultados apresentados pelo programa são: posição dos emissores ao longo do vão, pressão de operação, vazão, cor do bocal, largura da faixa de deposição, perda de carga no trecho entre o emissor em questão e o anterior e perda de carga acumulada. Todas essas informações são apresentadas na tela do computador e automaticamente é gerado um arquivo ("Sppc.txt") contendo as mesmas. Os resultados dos dimensionamentos das barras de pulverização do balanço são apresentados tanto na tela do computador como em dois arquivos distintos ("BalancoA.txt" e "BalancoB.txt"). Os arquivos de saída são gerados no mesmo diretório no qual encontra-se instalada a versão executável do programa SPPC.

Além desses resultados, pelo programa pode-se simular o cálculo da lâmina para qualquer vão do pivô, além do cálculo específico da lâmina de um determinado bocal disposto em qualquer um dos vãos que compõe o pivô.

O programa e as bibliotecas necessárias para sua execução foram reunidos em um pacote de instalação padrão Windows. Após a instalação, o programa pode ser acessado pelo menu iniciar/arquivo de programas. 


\section{RESULTADOS E DISCUSSÃO}

\subsection{Resultados das avaliações preliminares}

\subsubsection{Teejet Disc-Core}

Na avaliação desses emissores, embora seguidas as orientações do fabricante quanto à altura de instalação, espaçamento e pressão de operação, pôde-se constatar visualmente que sequer houve sobreposição dos jatos cônicos para toda a faixa de pressões avaliada. Outra constatação foi de que os perfis produzidos por cada uma das pontas apresentavam diferenças quanto ao ângulo de abertura, o que certamente influenciaria negativamente na qualidade da pulverização.

Além dos problemas descritos acima, o elevado custo de cada corpo para bico completo (cerca de US\$15.00) teria uma participação expressiva no custo final da barra de pulverização, o que dificilmente viabilizaria economicamente o seu emprego.

Diante dos problemas apresentados, buscaram-se alternativas para compor os elementos formadores de gotas, dentre essas os emissores descritos no tópico a seguir.

\subsubsection{Fogger 7800 e protótipo da barra de pulverização}

Três peculiaridades influenciaram, inicialmente, na escolha dos emissores Fogger 7800 como opção às pontas de pulverização de jato cônico cheio: o menor custo de cada conjunto emissor/válvula antigota (cerca de US\$2.50), a possibilidade de incorporação de dispositivos antigotas e o espectro de gotas apresentado no catálogo eletrônico 
fornecido pelo fabricante para os bocais de vazão nominal de $7 \mathrm{~L} / \mathrm{h}$ (vermelho), o qual encontra-se reproduzido na Figura 20.

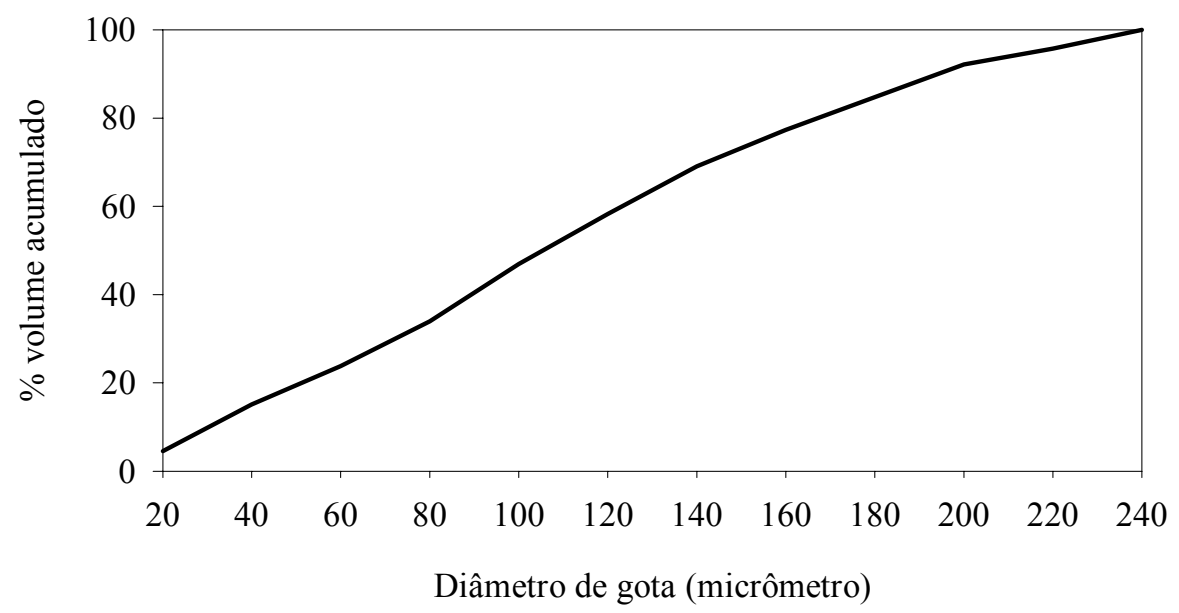

Figura 20 - Variação do tamanho de gotas e respectivas frações de volumes para o Fogger 7800, equipado com bocal vermelho, operando sob pressão de $300 \mathrm{kPa}$.

(Fonte: adaptado de Dan Sprinklers , 2001).

Com base nas informações apresentadas na Figura 20 , determinou-se por interpolação linear o DMV para esse emissor operando sob pressão de $300 \mathrm{kPa}$, resultando no valor de $105,4 \mu \mathrm{m}$.

Esse DMV enquadra-se dentro da faixa de tamanhos de gotas recomendada por Bode (1987) para aplicação de produtos químicos, podendo o espectro ser classificado como gotas finas de acordo com a preposição de Ozeki \& Kunz (s.d.).

Embora esses resultados tenham sido indicadores da possibilidade de uso desse modelo, no que se refere a tamanho de gotas, ainda seria possível utilizar outros diâmetros de bocais que, operando sob diferentes pressões, permitiriam almejar tamanhos de gotas diferenciados.

As avaliações visuais procedentes dos ensaios de distribuição de cada um dos modelos de bocais disponíveis, montados na estrutura desenvolvida para essa finalidade, foram aceitas como satisfatórias. Restaria, ainda, ter uma noção de como seria o 
desempenho das válvulas antigotas quando submetidas aos regimes intermitentes de operação.

Objetivando elucidar tais dúvidas, confeccionou-se uma outra estrutura em que inicialmente foi avaliada a resposta hidráulica de apenas cinco conjuntos emissores/válvulas antigotas espaçados de $6 \mathrm{~m}$, perfazendo uma barra com comprimento total de $30 \mathrm{~m}$. Os resultados dessa avaliação, aliados àqueles observados no ensaio de uniformidade de distribuição, embora visuais, tornaram-se decisivos na escolha desses emissores para a confecção da barra de pulverização.

Assim, decidiu-se que a próxima ação deveria ser o projeto da barra e sua montagem na forma de um protótipo, com o objetivo de testar seu funcionamento, a resposta hidráulica do sistema com todos os emissores presentes, e, possíveis alterações de vazões ao longo da barra decorrentes do regime intermitente de pulsos de vazões a que todo o sistema estaria submetido.

\subsection{Resultados da caracterização hidráulica dos emissores}

\subsubsection{Coeficiente de variação de fabricação}

Na Tabela 7 são apresentados os valores médios de vazão e CVF para cada um dos quatro modelos de bocais intercambiáveis do emissor Fogger 7800. 
Tabela 7. Vazão média observada para os quatro modelos de bocais disponíveis para o emissor Fogger 7800, montado com dispositivos antidrenantes, e respectivos coeficientes de variação de fabricação.

\begin{tabular}{ccccccccc}
\hline $\begin{array}{c}\text { Pressão } \\
(\mathrm{kPa})\end{array}$ & Azul & Laranão média $(\mathrm{L} / \mathrm{h})$ & \multicolumn{5}{c}{ CVF (\%) } \\
\hline 110 & 3,84 & 7,76 & 11,74 & 14,76 & 2,40 & 1,63 & 2,22 & 3,99 \\
150 & 4,55 & 8,79 & 13,67 & 16,54 & 2,51 & 1,74 & 2,26 & 3,00 \\
200 & 5,22 & 10,12 & 15,35 & 19,23 & 2,43 & 1,91 & 2,23 & 2,87 \\
250 & 5,74 & 11,19 & 17,26 & 21,49 & 2,48 & 2,09 & 2,61 & 3,28 \\
& \multicolumn{3}{c}{ Valores médios de CVF (\%) } & 2,46 & 1,84 & 2,33 & 3,28 \\
\hline
\end{tabular}

Esclarece-se que a pressão de $110 \mathrm{kPa}$ foi estipulada em razão de que algumas válvulas antigotas restringiam total ou parcialmente o fluxo quando submetidas a pressões inferiores a esse valor.

As condições do teste foram idênticas em todas as ocasiões; portanto, diferenças observadas na vazão dos bocais, quando submetidos a um mesmo valor de pressão, devem ser atribuídas ao processo de fabricação.

O CVF médio obtido para todas as pressões e diâmetros de bocais foi de 2,48\%, podendo ser classificados como de "uniformidade excelente", de acordo com a classificação proposta por Estados Unidos (1979).

\subsubsection{Equação característica da vazão em função da pressão}

$\mathrm{Na}$ Figura 21 encontram-se representadas graficamente as estimativas feitas com as equações ajustadas de pressão-vazão, obtidas para cada modelo de bocal estudado.

Os coeficientes de ajuste e os expoentes característicos dos emissores são apresentados na Tabela 8 . 


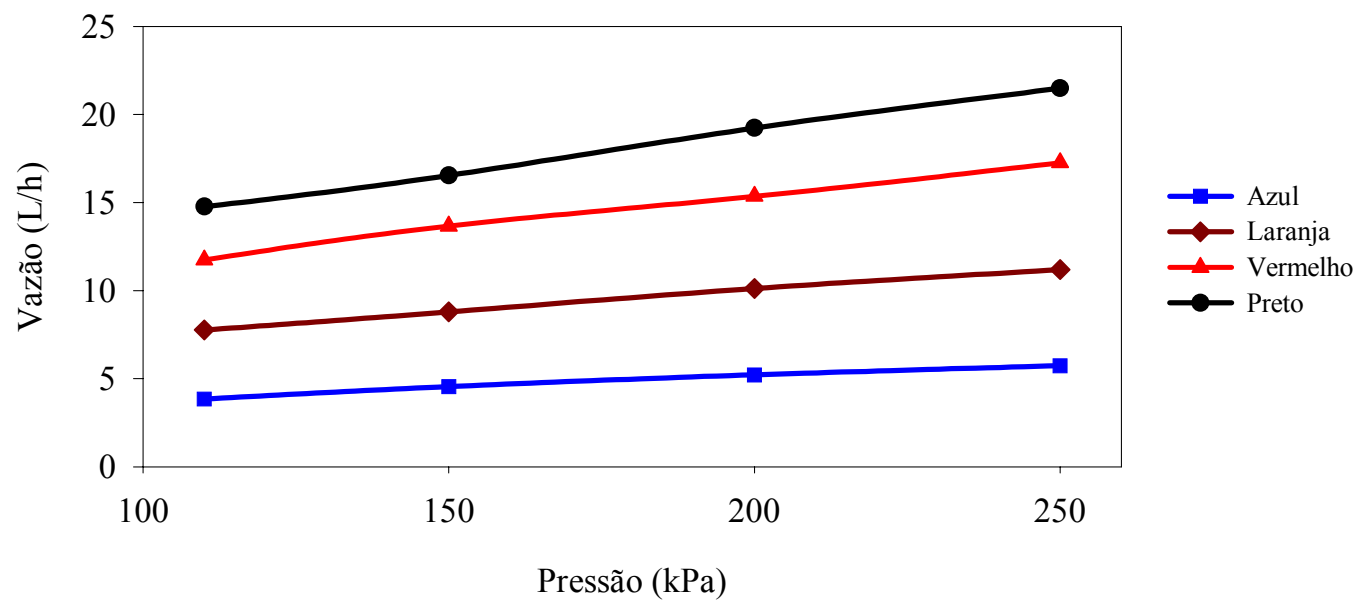

Figura 21 - Famílias de curvas pressão-vazão para o conjunto Fogger 7800/válvula reguladora de pressão, equipados com bocais azul, laranja, vermelho e preto (Tabela 8).

Tabela 8. Coeficientes de ajuste da equação $(\mathrm{K})$ e expoentes característicos (x) do Fogger 7800 equipado com quatro modelos de bocais e válvulas antigotas, operando sob pressões de 110 a $250 \mathrm{kPa}$, e respectivos coeficientes de determinação $\left(\mathrm{r}^{2}\right)$ das equações anamorfizadas.

\begin{tabular}{lccc}
\hline Bocal & $\mathrm{K}\left(\mathrm{L} / \mathrm{h} \cdot \mathrm{kPa}^{-\mathrm{x}}\right)$ & $\mathrm{x}$ & $\mathrm{r}^{2}$ \\
\hline Azul & 0,3884 & 0,4892 & 0,9971 \\
Vermelho & 0,9325 & 0,4497 & 0,9983 \\
Laranja & 1,3404 & 0,4620 & 0,9979 \\
Preto & 1,6571 & 0,4628 & 0,9937 \\
\hline
\end{tabular}

$\mathrm{r}^{2}$ crít $_{19,1 \%}=0,5490$ (Fonte: Weiss \& Hasset, 1982).

Comparando os valores dos coeficientes de determinação encontrados com o valor crítico tabelado a $1 \%$ de significância ( $\mathrm{r}^{2}$ crít), é possível concluir que as equações potenciais, recomendadas pela norma ISO 9260:1991(E) para esse tipo de caracterização, representam de maneira precisa a relação pressão-vazão para os quatro modelos de bocais avaliados. 


\subsubsection{Perfil de distribuição da precipitação}

Na Tabela 9 são apresentadas as intensidades de precipitações médias observadas ao longo de alcance do emissor.

Tabela 9. Intensidades médias de precipitação $(\mathrm{mm} / \mathrm{h})$ ao longo do raio molhado pelo Fogger 7800 operando sob pressão de $211 \mathrm{kPa}$.

\begin{tabular}{lcccccc}
\hline \multirow{2}{*}{ Bocal } & \multicolumn{5}{c}{ Raio de alcance (cm) } \\
& $0^{*}$ & 10 & 20 & 30 & 40 & 50 \\
\hline Azul & 63,93 & 39,66 & 10,35 & 1,79 & 0,27 & 0,02 \\
Laranja & 72,95 & 45,82 & 27,79 & 5,04 & 0,73 & 0,00 \\
Vermelho & 98,41 & 93,17 & 45,36 & 17,57 & 2,06 & 0,00 \\
Preto & 53,32 & 66,91 & 64,72 & 32,69 & 6,96 & 0,66 \\
\hline
\end{tabular}

*Disposto sob o emissor.

Percebe-se nos dados apresentados que os emissores equipados com bocais azuis e pretos apresentaram alcances superiores a $50 \mathrm{~cm}$, enquanto os alcances dos demais modelos encontram-se compreendidos entre 40 e $50 \mathrm{~cm}$.

Com as informações sobre as intensidades de precipitação e as respectivas distâncias de ocorrência ao longo do raio de alcance do emissor, por meio de análise de regressão, ajustaram-se equações no intuito de caracterizar o perfil médio de distribuição da precipitação, as quais encontram-se dispostas nas Figura 22. 


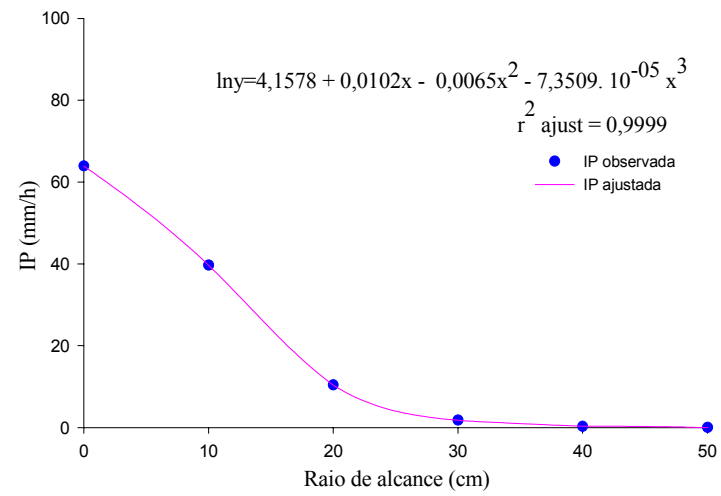

(a)

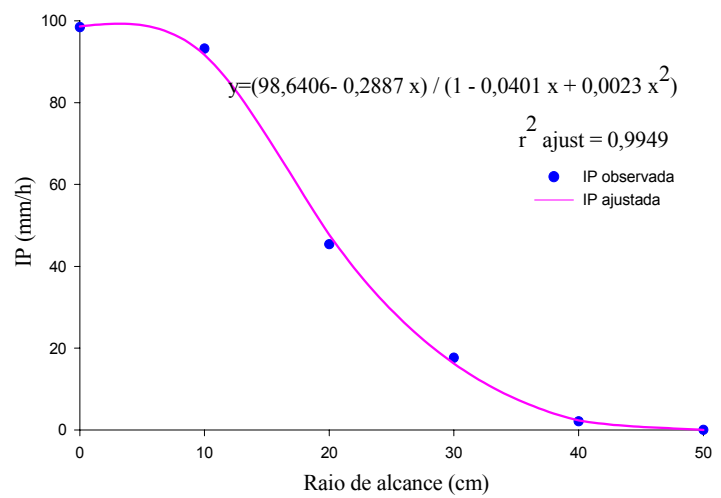

(c)

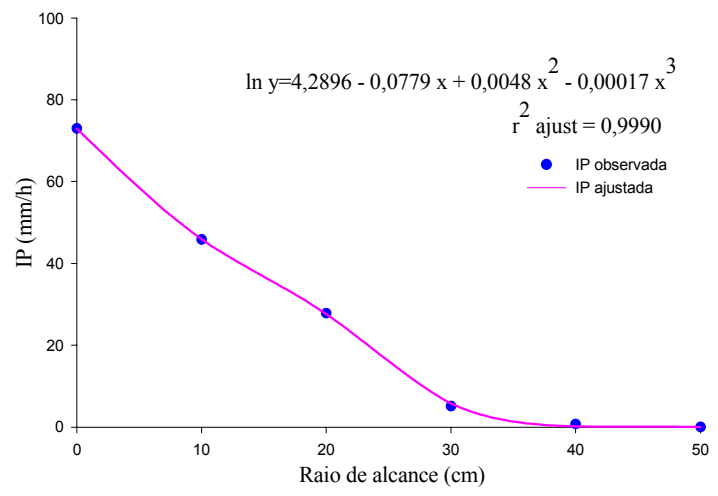

(b)

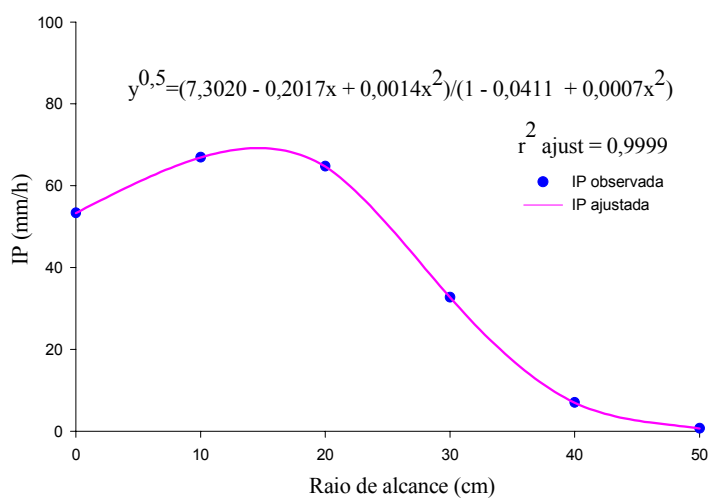

(d)

Figura 22 - Valores observados e ajustados de intensidade de precipitação média (IP) ao longo do raio de alcance do Fogger 7800 equipado com válvula antigota e bocal azul (a), laranja (b), vermelho (c) e preto (d).

Dentre todas as equações ajustadas pelo programa computacional, empregaramse as que apresentaram os mais elevados coeficientes de determinação. Além desse parâmetro de escolha, concomitantemente, optou-se por modelos mais simples e capazes de representar com maior fidelidade a tendência dos pontos observados.

\subsection{Simulações das distribuições lineares}

$\mathrm{Na}$ Tabela 10 são apresentados os resultados das simulações realizadas com objetivo de transformar as distribuições espaciais em lineares. Verifica-se que os 
alcances dos emissores, determinados por meio das equações ajustadas, são de 55, 46, 43 e $62 \mathrm{~cm}$ para os conjuntos emissores/válvulas antigotas equipados com bocais azuis, laranjas, vermelhos e pretos, respectivamente.

Tabela 10. Intensidades de precipitação $(\mathrm{mm} / \mathrm{h})$ acumuladas ao longo do raio de alcance do Fogger 7800 equipado com válvula antigota, para os quatro modelos de bocais disponíveis.

\begin{tabular}{|c|c|c|c|c|c|c|c|c|c|}
\hline \multirow{2}{*}{$\begin{array}{l}\text { Raio } \\
(\mathrm{cm})\end{array}$} & \multicolumn{4}{|c|}{ Modelo de bocal } & \multirow{2}{*}{$\begin{array}{l}\text { Raio } \\
(\mathrm{cm})\end{array}$} & \multicolumn{4}{|c|}{ Modelo de bocal } \\
\hline & Azul & Laranja & Vermelho & Preto & & Azul & Laranja & Vermelho & Preto \\
\hline $0^{*}$ & 1693,32 & 2230,24 & 4172,93 & 3996,40 & 32 & 44,71 & 85,41 & 414,67 & 957,46 \\
\hline 1 & 1686,38 & 2214,15 & 4169,85 & 3999,39 & 33 & 38,16 & 62,14 & 349,06 & 828,92 \\
\hline 2 & 1663,75 & 2183,68 & 4154,99 & 4003,59 & 34 & 32,54 & 44,16 & 289,57 & 712,04 \\
\hline 3 & 1625,53 & 2145,17 & 4125,80 & 4006,80 & 35 & 27,81 & 30,62 & 235,86 & 606,94 \\
\hline 4 & 1572,59 & 2101,42 & 4080,84 & 4007,57 & 36 & 23,82 & 20,70 & 187,85 & 513,41 \\
\hline 5 & 1506,83 & 2053,71 & 4019,15 & 4004,76 & 37 & 20,46 & 13,63 & 145,16 & 431,03 \\
\hline 6 & 1430,17 & 2002,59 & 3940,39 & 3997,32 & 38 & 17,62 & 8,72 & 107,78 & 359,18 \\
\hline 7 & 1344,93 & 1948,18 & 3844,69 & 3984,28 & 39 & 15,22 & 5,42 & 75,45 & 297,09 \\
\hline 8 & 1253,51 & 1890,40 & 3732,68 & 3964,69 & 40 & 13,19 & 3,27 & 48,15 & 243,92 \\
\hline 9 & 1158,28 & 1829,02 & 3605,48 & 3937,65 & 41 & 11,48 & 1,90 & 26,10 & 198,79 \\
\hline 10 & 1061,49 & 1763,77 & 3464,71 & 3902,27 & 42 & 10,02 & 1,07 & 9,62 & 160,81 \\
\hline 11 & 965,02 & 1694,44 & 3312,34 & 3857,70 & 43 & 8,78 & 0,58 & 0,25 & 129,09 \\
\hline 12 & 870,87 & 1620,81 & 3150,31 & 3803,13 & 44 & 7,73 & 0,29 & - & 102,82 \\
\hline 13 & 780,35 & 1542,81 & 2980,89 & 3737,86 & 45 & 6,71 & 0,13 & - & 81,24 \\
\hline 14 & 694,58 & 1460,45 & 2806,69 & 3661,28 & 46 & 5,94 & 0,01 & - & 63,64 \\
\hline 15 & 614,38 & 1373,96 & 2629,82 & 3572,91 & 47 & 5,17 & - & - & 49,41 \\
\hline 16 & 540,16 & 1283,69 & 2452,27 & 3472,46 & 48 & 4,61 & - & - & 37,99 \\
\hline 17 & 472,25 & 1190,22 & 2276,44 & 3359,84 & 49 & 4,01 & - & - & 28,91 \\
\hline 18 & 411,19 & 1094,30 & 2103,56 & 3235,25 & 50 & 3,48 & - & - & 21,74 \\
\hline 19 & 365,15 & 996,87 & 1935,38 & 3099,12 & 51 & 2,89 & - & - & 16,15 \\
\hline 20 & 307,32 & 899,04 & 1772,84 & 2952,22 & 52 & 2,48 & - & - & 11,82 \\
\hline 21 & 264,12 & 802,00 & 1617,05 & 2795,64 & 53 & 1,99 & - & - & 8,52 \\
\hline 22 & 226,37 & 707,07 & 1468,41 & 2630,74 & 54 & 1,30 & - & - & 6,02 \\
\hline 23 & 193,50 & 615,50 & 1327,73 & 2459,21 & 55 & 0,42 & - & - & 4,16 \\
\hline 24 & 164,93 & 528,56 & 1194,91 & 2282,98 & 56 & - & - & - & 2,80 \\
\hline 25 & 140,42 & 447,34 & 1070,23 & 2104,14 & 57 & - & - & - & 1,82 \\
\hline 26 & 119,29 & 372,38 & 953,77 & 1924,92 & 58 & - & - & - & 1,14 \\
\hline 27 & 101,35 & 305,59 & 845,24 & 1747,55 & 59 & - & - & - & 0,67 \\
\hline 28 & 85,97 & 246,18 & 744,50 & 1574,21 & 60 & - & - & - & 0,36 \\
\hline 29 & 72,91 & 194,70 & 651,34 & 1406,90 & 61 & - & - & - & 0,16 \\
\hline 30 & 61,96 & 151,03 & 565,50 & 1247,41 & 62 & - & - & - & 0,03 \\
\hline 31 & 52,61 & 114,80 & 486,71 & 1097,21 & 63 & - & - & - & - \\
\hline
\end{tabular}

Disposto sob o emissor. 


\subsection{Largura máxima da faixa de deposição}

Na Tabela 11 são apresentados das larguras máximas das faixas de deposição para cada um dos modelos de bocais estudados, determinados com base nos resultados das distribuições lineares obtidas no item anterior.

Tabela 11. Largura máxima da faixa de deposição $\left(\mathrm{e}_{\operatorname{máx}}\right)$, coeficientes de variação dos somatórios das intensidades de precipitação acumuladas (CV) e número de emissores que contribuíram para a sobreposição entre dois emissores consecutivos de mesmo modelo $(\mathrm{N})$.

\begin{tabular}{lccc}
\hline Bocal & $\mathrm{e}_{\text {máx }}(\mathrm{cm})$ & $\mathrm{CV}(\%)$ & $\mathrm{N}$ \\
\hline Azul & 27 & 8,62 & 6 \\
Laranja & 41 & 9,63 & 4 \\
Vermelho & 42 & 9,55 & 4 \\
Preto & 50 & 8,60 & 4 \\
\hline
\end{tabular}

Pelos valores de CV apresentados na Tabela 11, fica evidente que, na hipótese de os emissores escolhidos serem empregados como elementos formadores de gotas em pulverização terrestre com deslocamento contínuo, quando avaliados em mesas de distribuição e respeitando os espaçamentos máximos para cada tipo de bocal, ter-se-íam teoricamente valores de CV inferiores a 10\%. Assim, de acordo com o julgamento de valores de CV apresentado por Cupery (1987), a pulverização estaria apta a atender os mais elevados padrões de qualidade adotados por pesquisadores de países como os Estados Unidos da América, Canadá e Escandinávia. Excetuariam-se apenas os bocais de cor laranja, quando submetidos à classificação seguida por pesquisadores da África do Sul, os quais seriam julgados como "bons" por apresentarem CV entre 9 e 12\%, embora os resultados simulados encontrem-se próximos ao limite inferior dessa classificação. 


\subsection{Posicionamento e volume de pulverização do primeiro emissor}

O primeiro emissor foi posicionado a 29,9m de distância do ponto de alimentação de cada uma das barras de pulverização, como pode ser observado na Figura 23.

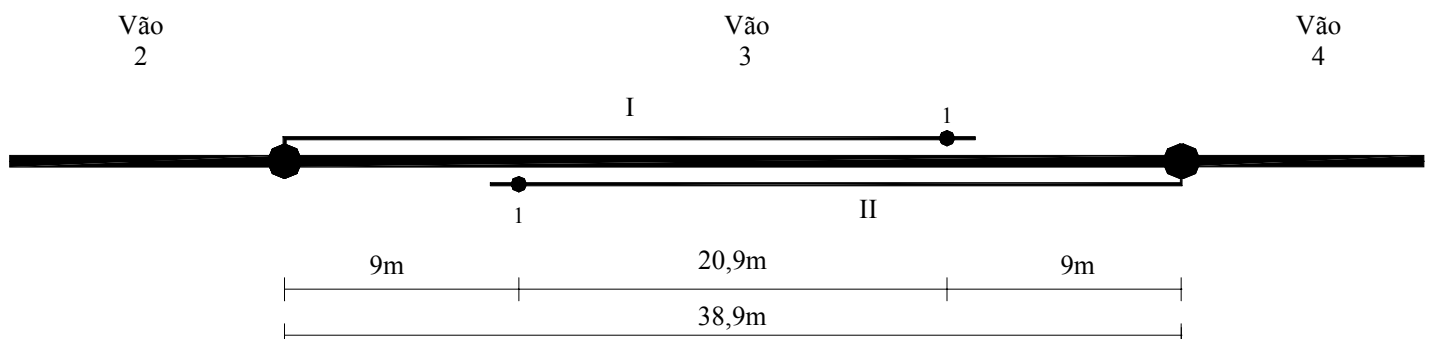

Figura 23 - Posicionamento dos primeiros emissores em cada uma das barras de pulverização (I e II).

Entretanto, para a distribuição dos emissores ao longo da barra de pulverização, considerou-se que o início dessa seria a extremidade ausente de movimento, e, portanto, o primeiro emissor estaria distanciado de $9 \mathrm{~m}$ contados a partir desse ponto.

A calda calculada para essa referida posição, por meio da eq. (11), foi de 3.631,72L/ha. Esses resultados foram obtidos considerando uma vazão de 5,32L/h (bocal azul) para o emissor, comprimento da torre de $38,9 \mathrm{~m}$, velocidade de deslocamento de $234,5 \mathrm{~m} / \mathrm{h}$ e largura máxima da faixa de deposição de $27 \mathrm{~cm}$. Esse seria o volume teórico por unidade de área que o sistema de pulverização aplicaria em 1,04h ( Tr), caso não fosse utilizado o sistema de intermitência utilizado neste trabalho.

\subsection{Resultados do dimensionamento da barra de pulverização}

Determinaram-se as posições e os espaçamentos entre os demais emissores de cada barra de pulverização por intermédio das eq.(12) e eq.(15), respectivamente, cujos resultados são apresentados na Tabela 12. 
Nessa mesma tabela são apresentados, além dos dois parâmetros citados anteriormente, o número do bocal, a sua coloração, as vazões e perdas de carga acumuladas, ambas obtidas para cada trecho de tubulação entre dois emissores consecutivos.

A perda de carga total acumulada ao longo da barra foi estimada em 9,9961kPa, como mostrado na Tabela 12. Considerando o deslocamento do equipamento em terreno plano, essa variação de pressão proporcionaria uma redução de vazão próxima a 2,4\% nos últimos emissores, e, conseqüentemente, o volume de pulverização por unidade de área seria decrescido desse mesmo valor nas últimas posições de instalação dos emissores. Entretanto, por se tratar de duas barras de pulverização por cada vão do pivô, espera-se que ocorram compensações dessas variações, resultando menores alterações nos volumes recebidos pelos alvos da pulverização.

A calda aplicada pelo primeiro emissor foi considerada a mesma para os demais emissores no cálculo da planilha apresentada na Tabela 12. 
Tabela 12. Resultados do dimensionamento da barra de pulverização.

\begin{tabular}{|c|c|c|c|c|c|c|c|c|c|c|c|}
\hline $\mathrm{i}$ & $\begin{array}{c}\mathrm{P}_{\mathrm{i}} \\
(\mathrm{m})\end{array}$ & $\begin{array}{c}\mathrm{d}_{\mathrm{i}} \\
(\mathrm{m})\end{array}$ & $\operatorname{Cor}_{i}$ & $\begin{array}{c}\mathrm{qa}_{\mathrm{i}} \\
(\mathrm{L} / \mathrm{h})\end{array}$ & $\begin{array}{c}\mathrm{hfa}_{\mathrm{i}} \\
(\mathrm{kPa})\end{array}$ & $\mathrm{i}$ & $\begin{array}{c}\mathrm{P}_{\mathrm{i}} \\
(\mathrm{m})\end{array}$ & $\begin{array}{c}\mathrm{d}_{\mathrm{i}} \\
(\mathrm{m})\end{array}$ & $\operatorname{Cor}_{i}$ & $\begin{array}{c}\mathrm{qa}_{\mathrm{i}} \\
(\mathrm{L} / \mathrm{h})\end{array}$ & $\begin{array}{c}\mathrm{hfa}_{\mathrm{i}} \\
(\mathrm{kPa})\end{array}$ \\
\hline 1 & 9,00 & 0,27 & Azul & 5,32 & 0,00002 & 49 & 25,85 & 0,35 & Preto & 655,53 & 1,34774 \\
\hline 2 & 9,27 & 0,26 & Azul & 10,64 & 0,00007 & 50 & 26,20 & 0,34 & Preto & 675,26 & 1,44437 \\
\hline 3 & 9,52 & 0,26 & Azul & 15,96 & 0,00018 & 51 & 26,54 & 0,34 & Preto & 694,99 & 1,54484 \\
\hline 4 & 9,78 & 0,25 & Azul & 21,28 & 0,00035 & 52 & 26,88 & 0,34 & Preto & 714,72 & 1,64919 \\
\hline 5 & 10,02 & 0,24 & Azul & 26,60 & 0,00060 & 53 & 27,21 & 0,33 & Preto & 734,45 & 1,55745 \\
\hline 6 & 10,26 & 0,24 & Azul & 31,92 & 0,00093 & 54 & 24,54 & 0,33 & Preto & 754,18 & 1,86968 \\
\hline 7 & 10,50 & 0,23 & Azul & 37,24 & 0,00137 & 55 & 27,87 & 0,32 & Preto & 773,91 & 1,98588 \\
\hline 8 & 10,72 & 0,23 & Azul & 42,56 & 0,00190 & 56 & 28,19 & 0,32 & Preto & 793,64 & 2,10612 \\
\hline 9 & 10,95 & 0,22 & Azul & 47,88 & 0,00255 & 57 & 28,51 & 0,32 & Preto & 813,37 & 2,23041 \\
\hline 10 & 11,17 & 0,22 & Azul & 53,20 & 0,00331 & 58 & 28,82 & 0,31 & Preto & 833,10 & 2,35879 \\
\hline 11 & 11,48 & 0,41 & Lar & 63,55 & 0,00513 & 59 & 29,13 & 0,31 & Preto & 852,83 & 2,49130 \\
\hline 12 & 11,89 & 0,40 & Lar & 73,90 & 0,00742 & 60 & 29,44 & 0,31 & Preto & 872,56 & 2,62797 \\
\hline 13 & 12,28 & 0,38 & Lar & 84,25 & 0,01021 & 61 & 29,74 & 0,30 & Preto & 892,29 & 2,76883 \\
\hline 14 & 12,66 & 0,37 & Lar & 94,60 & 0,01355 & 62 & 30,05 & 0,30 & Preto & 912,02 & 2,91392 \\
\hline 15 & 13,03 & 0,36 & Lar & 104,95 & 0,01744 & 63 & 30,34 & 0,30 & Preto & 931,75 & 3,06326 \\
\hline 16 & 13,39 & 0,35 & Lar & 115,30 & 0,02193 & 64 & 30,64 & 0,29 & Preto & 951,48 & 3,21688 \\
\hline 17 & 13,73 & 0,34 & Lar & 125,65 & 0,02703 & 65 & 30,93 & 0,29 & Preto & 971,21 & 3,37483 \\
\hline 18 & 14,07 & 0,34 & Lar & 136,00 & 0,03276 & 66 & 31,22 & 0,29 & Preto & 990,94 & 3,53712 \\
\hline 19 & 14,41 & 0,33 & Lar & 146,35 & 0,03914 & 67 & 31,51 & 0,29 & Preto & $1.010,67$ & 3,70379 \\
\hline 20 & 14,73 & 0,32 & Lar & 156,70 & 0,04620 & 68 & 31,79 & 0,28 & Preto & $1.030,40$ & 3,87487 \\
\hline 21 & 15,05 & 0,31 & Lar & 167,05 & 0,05394 & 69 & 32,08 & 0,28 & Preto & $1.050,13$ & 4,05039 \\
\hline 22 & 15,36 & 0,31 & Lar & 177,40 & 0,06239 & 70 & 32,36 & 0,28 & Preto & $1.069,86$ & 4,20338 \\
\hline 23 & 15,66 & 0,30 & Lar & 187,75 & 0,07157 & 71 & 32,36 & 0,28 & Preto & $1.089,59$ & 4,41486 \\
\hline 24 & 15,96 & 0,30 & Lar & 198,10 & 0,08149 & 72 & 32,91 & 0,27 & Preto & $1.109,32$ & 4,60387 \\
\hline 25 & 16,26 & 0,29 & Lar & 208,45 & 0,09216 & 73 & 33,18 & 0,27 & Preto & $1.129,05$ & 4,79743 \\
\hline 26 & 16,54 & 0,29 & Lar & 218,80 & 0,10360 & 74 & 33,45 & 0,27 & Preto & $1.148,78$ & 4,99558 \\
\hline 27 & 16,83 & 0,28 & Lar & 229,15 & 0,11583 & 75 & 33,72 & 0,27 & Preto & $1.168,51$ & 5,19833 \\
\hline 28 & 17,18 & 0,42 & Verm & 245,04 & 0,13552 & 76 & 33,99 & 0,27 & Preto & $1.188,24$ & 5,40572 \\
\hline 29 & 17,60 & 0,41 & Verm & 260,93 & 0,15703 & 77 & 34,25 & 0,26 & Preto & $1.207,97$ & 5,61778 \\
\hline 30 & 18,05 & 0,50 & Preto & 280,66 & 0,18607 & 78 & 34,51 & 0,26 & Preto & $1.227,71$ & 5,83452 \\
\hline 31 & 18,55 & 0,49 & Preto & 300,39 & 0,21799 & 79 & 34,77 & 0,26 & Preto & $1.247,43$ & 6,05599 \\
\hline 32 & 19,03 & 0,47 & Preto & 320,12 & 0,25285 & 80 & 35,03 & 0,26 & Preto & $1.267,16$ & 6,28220 \\
\hline 33 & 19,49 & 0,46 & Preto & 339,85 & 0,29071 & 81 & 35,29 & 0,26 & Preto & $1.286,89$ & 6,51318 \\
\hline 34 & 19,95 & 0,45 & Preto & 359,58 & 0,33163 & 82 & 35,54 & 0,25 & Preto & $1.306,62$ & 6,74896 \\
\hline 35 & 20,40 & 0,44 & Preto & 379,31 & 0,37567 & 83 & 35,79 & 0,25 & Preto & $1.362,35$ & 6,98956 \\
\hline 36 & 20,83 & 0,43 & Preto & 399,04 & 0,42288 & 84 & 36,05 & 0,25 & Preto & $1.346,08$ & 7,23501 \\
\hline 37 & 21,26 & 0,42 & Preto & 418,77 & 0,47331 & 85 & 36,29 & 0,25 & Preto & $1.365,81$ & 7,48534 \\
\hline 38 & 21,68 & 0,42 & Preto & 438,50 & 0,52703 & 86 & 36,54 & 0,25 & Preto & $1.385,54$ & 7,74056 \\
\hline 39 & 22,09 & 0,41 & Preto & 458,23 & 0,58407 & 87 & 36,79 & 0,24 & Preto & $1.405,27$ & 8,00072 \\
\hline 40 & 22,50 & 0,40 & Preto & 477,96 & 0,64450 & 88 & 37,03 & 0,24 & Preto & $1.425,00$ & 8,26582 \\
\hline 41 & 22,90 & 0,39 & Preto & 497,69 & 0,70834 & 89 & 37,27 & 0,24 & Preto & $1.444,73$ & 8,53589 \\
\hline 42 & 23,29 & 0,39 & Preto & 517,42 & 0,77566 & 90 & 37,52 & 0,24 & Preto & $1.464,46$ & 8,81097 \\
\hline 43 & 23,67 & 0,38 & Preto & 537,15 & 0,84650 & 91 & 37,75 & 0,24 & Preto & $1.484,19$ & 9,09106 \\
\hline 44 & 24,05 & 0,37 & Preto & 556,88 & 0,92089 & 92 & 37,99 & 0,24 & Preto & $1.503,92$ & 9,37621 \\
\hline 45 & 24,42 & 0,37 & Preto & 576,61 & 0,99889 & 93 & 38,23 & 0,24 & Preto & $1.523,65$ & 9,66642 \\
\hline 46 & 24,79 & 0,36 & Preto & 596,34 & 1,08053 & 94 & 38,46 & 0,23 & Preto & $1.543,38$ & 9,96174 \\
\hline 47 & 25,15 & 0,36 & Preto & 616,07 & 1,16586 & 95 & 38,70 & - & Preto & $1.563,11^{*}$ & 9,99610 \\
\hline 48 & 25,50 & 0,35 & Preto & 635,80 & 1,25492 & & & & & & \\
\hline
\end{tabular}

i: número de ordem do emissor; $\mathrm{P}_{\mathrm{i}}$ : posição do emissor ao longo do vão do pivô; $\mathrm{d}_{\mathrm{i}}$ : distância entre o iésimo emissor e seu subseqüente; cor ${ }_{\mathrm{i}}$ : cor do i-ésimo emissor; qa $\mathrm{i}_{\mathrm{i}}$ vazão acumulada até o i-ésimo emissor; hfa $\mathrm{i}$ : perda de carga acumulada até o i-ésimo emissor, * vazão transportada entre o último emissor e a válvula solenóide. 
Os valores de intensidade de precipitação acumulada para cada uma das barras de pulverização, gerados a partir dos perfis de distribuição de cada emissor, considerando os espaçamentos entre cada emissor apresentados na Tabela 12, resultaram nas intensidades de precipitação acumuladas apresentadas na Figura 24.

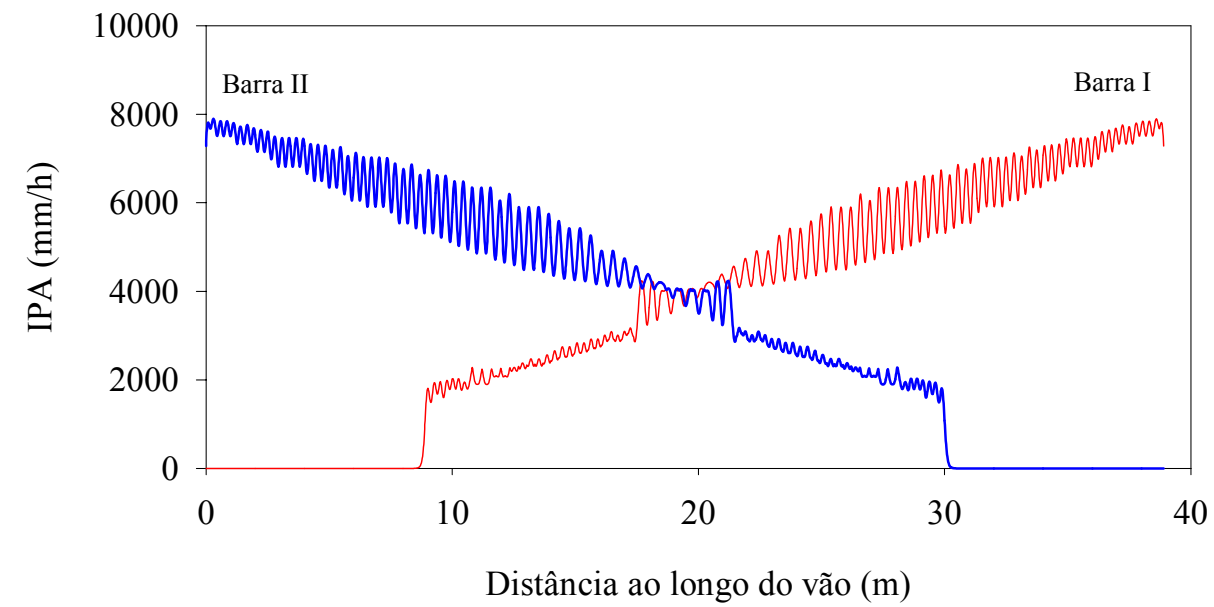

Figura 24 - Intensidades de precipitações acumuladas (IPA) ao longo do vão, estimadas para cada uma das barras de pulverização (I e II).

Ao analisar isoladamente a intensidade de precipitação acumulada de cada barra de pulverização apresentada na Figura 24, observa-se que tais valores são crescentes de uma determinada extremidade do vão para a outra. Isso ocorre em razão de que ambas as barras foram projetadas visando a compensar as diferentes velocidades de deslocamento que ocorrem ao longo do vão.

Tanto nos segmentos inicial como no final do vão, cobertos apenas por uma barra de pulverização, a intensidade de precipitação acumulada deve aproximar-se dos valores resultantes da aplicação das duas barras, de maneira a assegurar a qualidade da aplicação.

Na Figura 25 são apresentadas as intensidades de precipitações acumuladas totais, provenientes da associação das duas barras de pulverização 


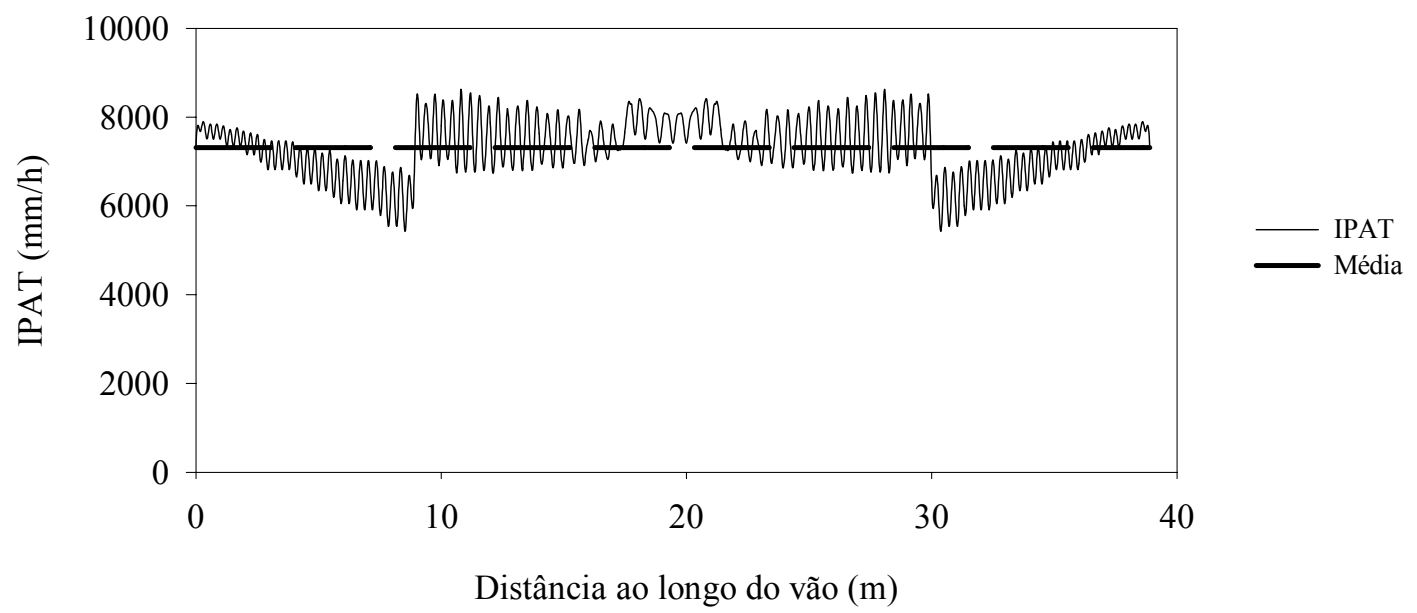

Figura 25 - Intensidades de precipitações acumuladas totais (IPAT) estimadas ao longo do vão, resultantes da associação das duas barras de pulverização.

Observa-se pelos dados apresentados na Figura 25 que os trechos inicial e final do vão apresentam valores da intensidade de precipitação decrescentes das extremidades para o centro desse. Nestes trechos, o volume aplicado é proveniente de apenas uma das barras de pulverização. Dessa forma, a quantidade de líquido depositado sobre o alvo tende a diminuir, até as posições onde a deposição passa a ser feita por duas barras $(9,0$ e 28,9m). A partir dessas posições, em direção ao centro do vão, a uniformidade é restabelecida em razão da sobreposição das duas barras. Uma possível solução para esse problema seria o aumento do comprimento das barras de pulverização. Embora esse aumento seja possível, quanto mais próximo da torre de sustentação oposta ao ponto de alimentação da barra, maior será a intensidade de precipitação do primeiro emissor, o que resultaria em acréscimos do volume de pulverização em toda a extensão da barra, contrariando um dos objetivos desse trabalho.

Todo o projeto de posicionamento dos emissores ao longo da barra de pulverização resultou, após a simulação das sobreposições, em coeficientes de variação da ordem de 8,6\%. Esse valor pode ser considerado "aceitável" em situações de aplicações terrestres, segundo Cupery (1987). Entretanto, é de se esperar que tal indicador de uniformidade de distribuição apresente maiores valores quando obtidos em 
situações de campo, de acordo com as informações de Gerling \& Solie, citados por Cupery (1987).

\subsection{Avaliações do protótipo no laboratório}

\subsubsection{Resposta hidráulica do sistema}

Após a completa montagem do protótipo no laboratório, obedecendo-se aos espaçamentos e posições dos emissores evidenciados na Tabela 12, o equipamento foi colocado em operação com tempos de abertura e fechamento da válvula solenóide de 1 e 9s (ligada/desligada), respectivamente. Todos os emissores entraram em operação simultaneamente à abertura da válvula, e, da mesma forma, deixaram de aplicar a calda imediatamente após o fechamento dessa. Vale esclarecer que essas observações somente tornaram-se possíveis após a completa escorva da barra e que a relação de tempo programada atenderia, teoricamente, a uma vazão dez vezes menor a que se observaria caso a barra fosse operada sem intermitência.

\subsubsection{Variação de vazão de emissores semelhantes ao longo da barra}

Na Figura 26 são apresentados os resultados da avaliação da vazão de emissores de vazões semelhantes, identificados previamente em outro ensaio complementar, quando instalados no início, meio e fim da barra de pulverização. De um total de 25 emissores avaliados nesse ensaio, os três que apresentaram vazões mais próximas foram identificados por E1, E2 e E3. 


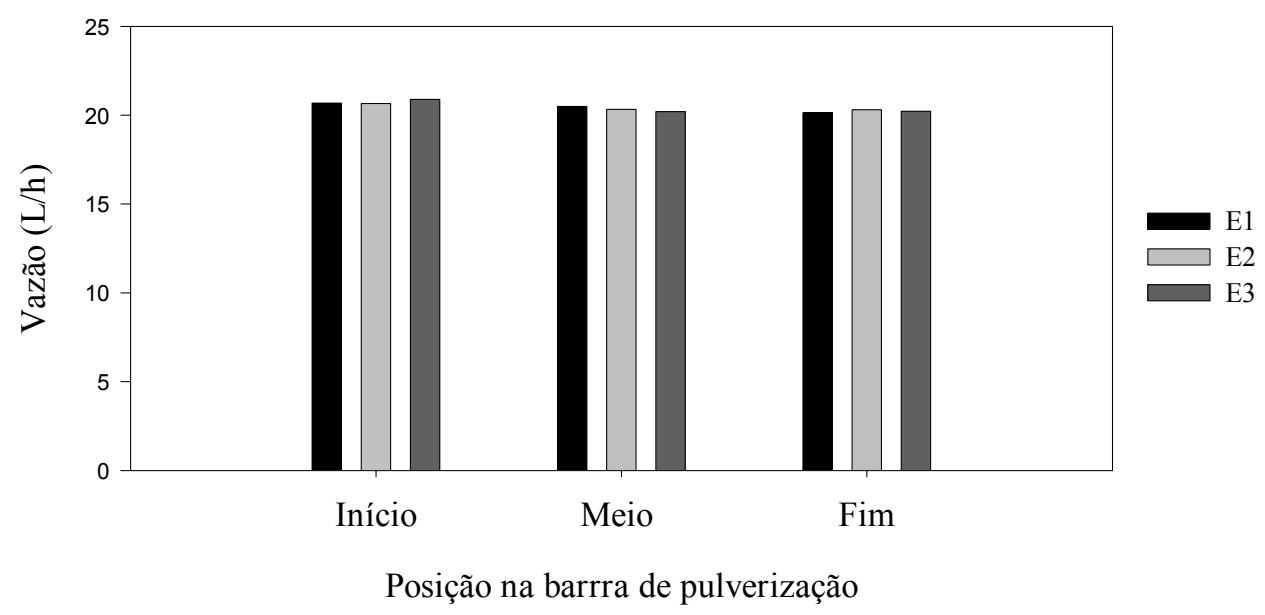

Figura 26 - Vazão de emissores (E1, E2 e E3) equipados com válvulas antigotas e bocais pretos, posicionados no início, meio e fim da barra de pulverização, submetidos a um único pulso com duração de 3 minutos, sob pressão de $211 \mathrm{kPa}$.

As vazões médias produzidas pelos emissores, em cada uma das posições apresentadas na Figura 26 foram de 20,74, 20,33 e 20,22L/h, respectivamente para as posições início, meio e fim. Esses resultados pouco superam o valor da vazão de 19,73L/h que o emissor deveria apresentar para as mesmas condições, obtido com base na equação característica do modelo em questão. Tais alterações, provavelmente, estejam relacionadas a erros metodológicos próprios de avaliações. Também poderiam decorrer da operação das válvulas solenóide e antigotas, muito embora tenham sido abertas e fechadas apenas uma vez durante esse ensaio, por se tratar de um único pulso com duração de 3 minutos.

Na Figura 27 são apresentados os resultados do mesmo teste, porém, os valores médios de vazão são provenientes de 360 pulsos com duração de 0,5s cada, totalizando um tempo de abertura idêntico ao teste realizado anteriormente. 


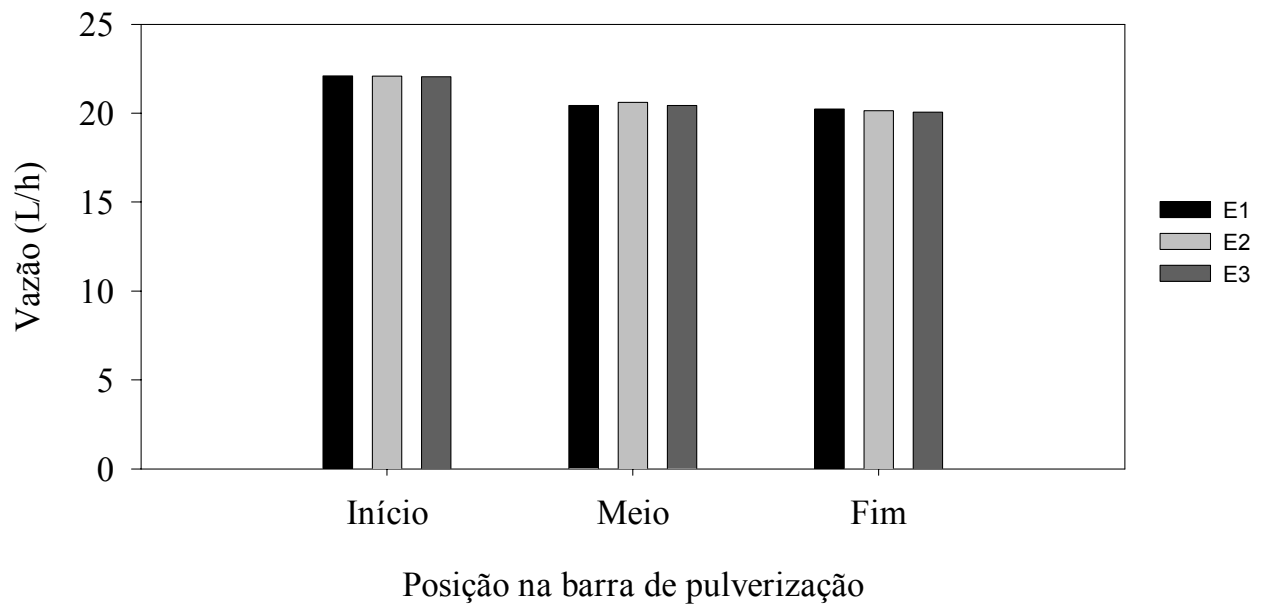

Figura 27 - Vazão de emissores (E1, E2 e E3) equipados com válvulas antigotas e bocais pretos, posicionados no início, meio e fim da barra de pulverização, submetidos a 360 pulsos com duração de $0,5 \mathrm{~s}$ cada um, sob pressão de $211 \mathrm{kPa}$.

Sob a condição de intermitência, verificou-se que as vazões médias são de 22,08, 20,49 e $20,14 \mathrm{~L} / \mathrm{h}$, superando em 6,46 e $0,79 \%$ as vazões observadas para a condição de apenas um único pulso, nas posições de início e meio da barra. Contrariamente a essa tendência, a vazão no final da barra decresceu $0,4 \%$ quando determinada sob o regime intermitente. A inércia do movimento do fluido no momento de abertura das válvulas, o tempo de resposta hidráulica destas e o tempo de resposta elétrica do periférico utilizado para o gerenciamento dos pulsos poderiam ser citados como possíveis causas da alteração de vazão (Figuras 26 e 27). Uma outra possibilidade seria que as válvulas reguladoras de pressão, na maioria dos modelos, atuam eficientemente para determinadas faixas específicas de vazão, o que não acontece nos momentos de fechamento da válvula solenóide. Assim, quando da abertura dessas, os primeiros emissores estariam sujeitos a valores de pressão mais elevados e, conseqüentemente, produziriam maiores vazões. Em decorrência dessa situação, as perdas de carga nos trechos iniciais da barra também seriam maiores e os últimos emissores estariam, por esse motivo, sujeitos a menores pressões e vazões. 
Entretanto, como o sistema foi concebido para operar com duas barras de pulverização, montadas em direções opostas, os volumes distribuídos sobre os alvos são

provenientes de ambas, podendo ocorrer, supostamente, efeitos que influenciariam na uniformidade de aplicação.

\subsection{Avaliações do sistema de pulverização no campo}

\subsubsection{Caracterização dos tamanhos de gotas}

Na Tabela 13 são apresentados os resultados obtidos no cálculo do DMV e DMN em cada uma das posições avaliadas ao longo do vão do pivô (Figura 19).

Tabela 13. Valores médios de DMV e DMN observados nas tres linhas de avaliação (L1, L2 e L3) em diferentes posições ao longo do vão do pivô.

\begin{tabular}{|c|c|c|c|c|c|c|c|c|}
\hline \multirow{2}{*}{$\begin{array}{l}\text { Distância } \\
\text { (m) }\end{array}$} & \multicolumn{4}{|c|}{$\mathrm{DMV}(\mu \mathrm{m})$} & \multicolumn{4}{|c|}{$\mathrm{DMN}(\mu \mathrm{m})$} \\
\hline & L1 & L 2 & L3 & Média & L1 & L 2 & L3 & Média \\
\hline 2,00 & 108,82 & 154,72 & 127,81 & 130,45 & 88,99 & 108,82 & 88,99 & 95,60 \\
\hline 10,72 & 146,00 & 108,82 & 127,81 & 127,54 & 88,99 & 88,99 & 108,82 & 95,60 \\
\hline 19,45 & 108,82 & 146,00 & 127,81 & 127,54 & 88,99 & 108,82 & 108,82 & 102,21 \\
\hline 28,18 & 127,81 & 127,81 & 127,81 & 127,81 & 108,82 & 108,82 & 88,99 & 102,21 \\
\hline 36,90 & 136,90 & 108,82 & 108,82 & 118,18 & 108,82 & 88,99 & 88,99 & 95,60 \\
\hline \multicolumn{4}{|c|}{ Média geral } & 126,30 & & & & 98,25 \\
\hline
\end{tabular}

Considerando os resultados obtidos em todas as posições avaliadas, verifica-se que o DMV está compreendido entre 108,82 e $154,72 \mu \mathrm{m}$, sendo seu valor médio de $126,30 \mu \mathrm{m}$ (Tabela 13).

Segundo a classificação proposta por Ozeki \& Kunz (s.d.), essas gotas se enquadrariam como "gotas finas" e, dessa forma, conforme Bode (1987), estariam aptas à aplicação de defensivos agrícolas. Esses resultados, de acordo com Matthews (1992), acompanham a tendência atual de aplicações com volumes reduzidos e diâmetros menores. Entretanto, como em qualquer tipo de pulverização, restrições à aplicação 
devem ser impostas para que a qualidade dessa não venha a ser comprometida em condições de ventos fortes $(\geq 10 \mathrm{~km} / \mathrm{h})$ e/ou baixa umidade relativa do ar $(\leq 50 \%)$.

De acordo com os resultados apresentados na Tabela 13, os valores mínimo, médio e máximo de DMN foram de 89,00, 98,25 e 108,82 $\mu \mathrm{m}$, respectivamente.

$\mathrm{Na}$ mesma tabela pode-se verificar que tanto os resultados de DMV como DMN apresentam coincidência para determinadas posições avaliadas. Esse fato, provavelmente, esteja relacionado com a metodologia de cálculo utilizada no software E-Sprinkle, onde os diâmetros enquadrariam-se dentro de classes de tamanhos préestabelecidos.

O coeficiente de dispersão do espectro de gotas produzidos pelas duas barras de pulverização foi de 1,29. Esse valor foi calculado com base nos valores médios gerais de DMV e DMN. Por ser inferior a 1,4, de acordo com Johnstone citado por Matuo (1990), permite classificar o espectro de gotas como homogêneo, enquadrando-se como CDA (controlled drop application), condição raramente observada em pulverizadores convencionais.

\subsubsection{Uniformidade de aplicação}

Nas Figuras 28, 29 e 30 pode-se visualizar os resultados dos volumes de pulverização obtidos por meio de papel filtro, determinados mediante as diferentes combinações de tempos ligados e desligados a que o sistema de pulverização foi submetido. Percebe-se nesses resultados que a relação entre os tempos ligado e desligado influencia diretamente o volume de pulverização aplicado.

Embora existam diferenças nos resultados observados em cada um dos pontos e também nas repetições, a redução dos volumes de pulverização, decorrente da intermitência do sistema, possibilitou a aplicação de volumes que variaram de 246 a 543L/ha. Assim, acredita-se que a programação de outras relações permita almejar caldas superiores e inferiores às estabelecidas nesse trabalho. Entretanto, todos outros possíveis valores, obviamente, devem ser submetidos a novos ensaios para prévia avaliação da uniformidade de distribuição. 


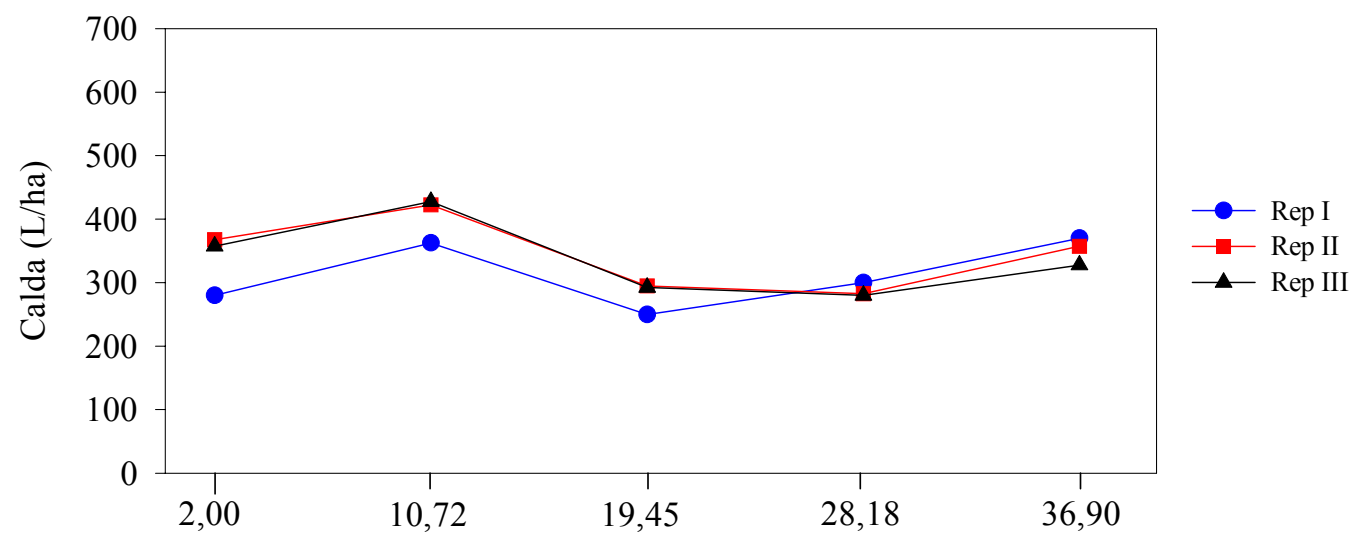

Distância ao longo do vão (m)

(a)

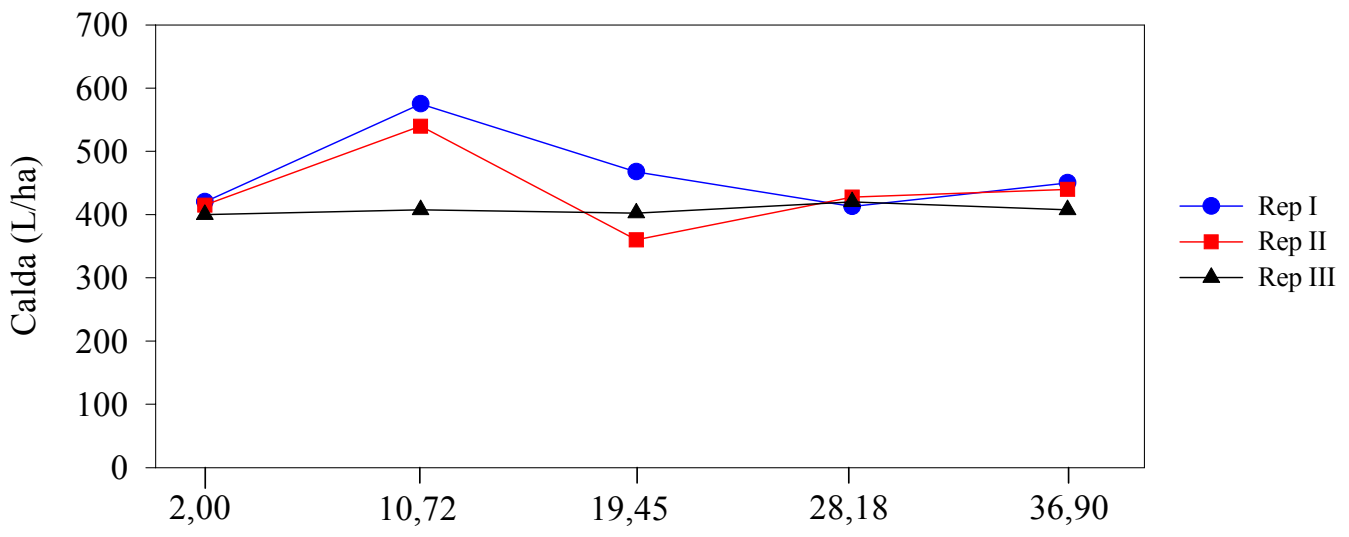

Distância ao longo do vão (m)

(b)

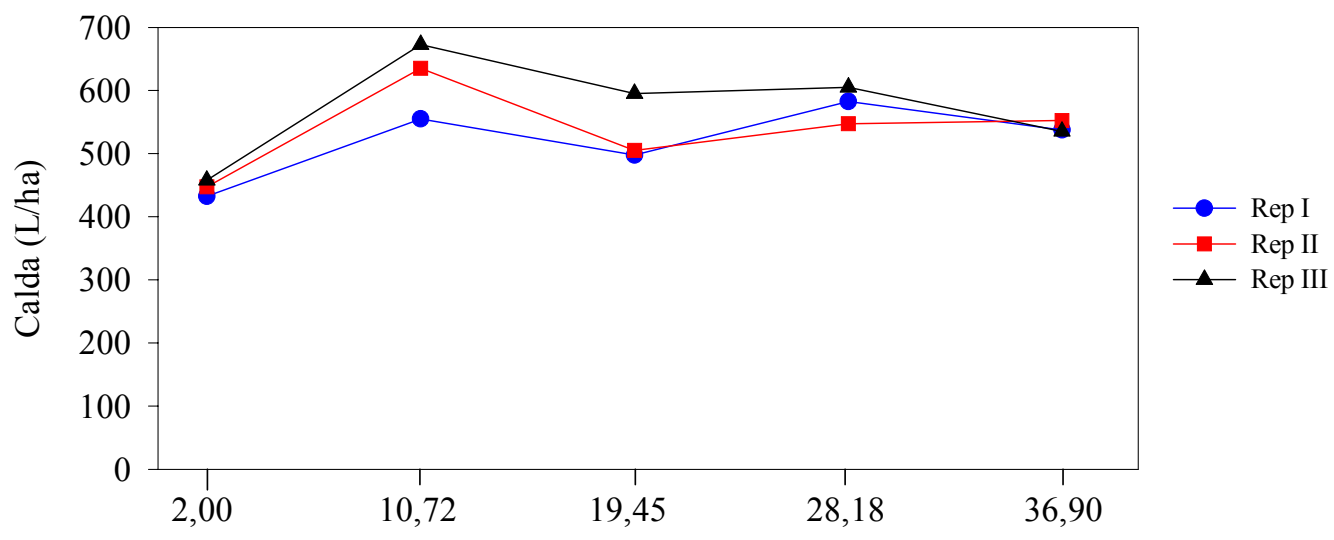

Distância ao longo do vão (m)

(c)

Figura 28 - Volumes de calda determinados para tempos ligados e desligados de $0,3 / 2,5 \mathrm{~s}$ (a), $0,4 / 2,5 \mathrm{~s}$ (b) e $0,5 / 2,5 \mathrm{~s}$ (c) nas repetições I, II e III. 


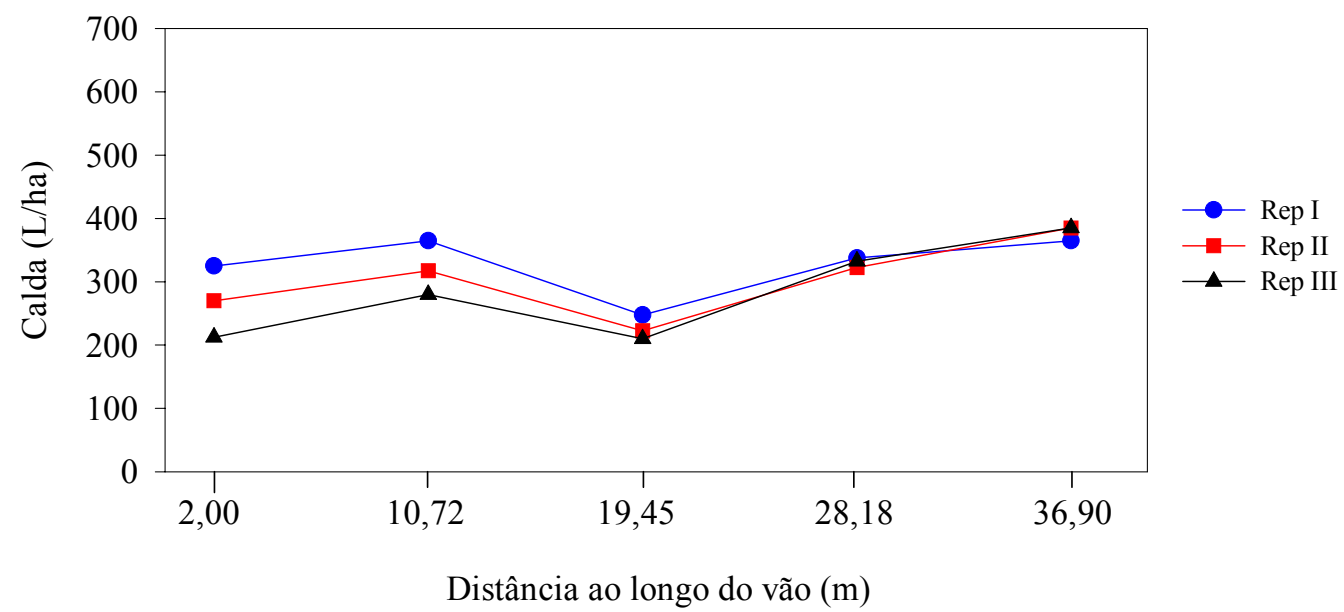

(a)

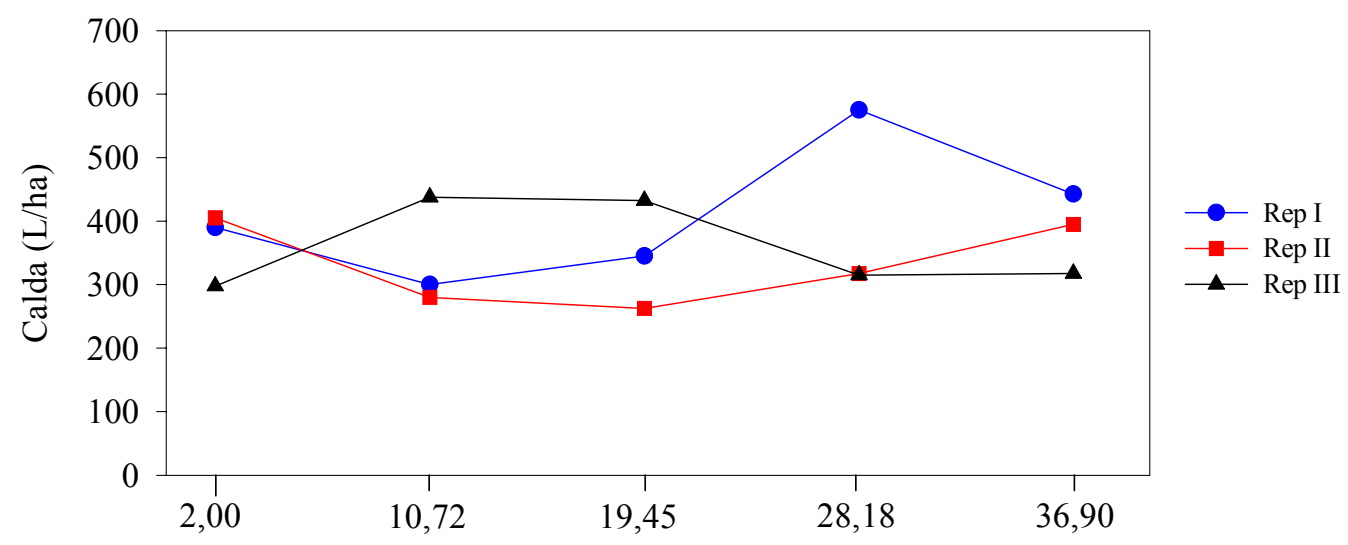

Distância ao longo do vão (m)

(b)

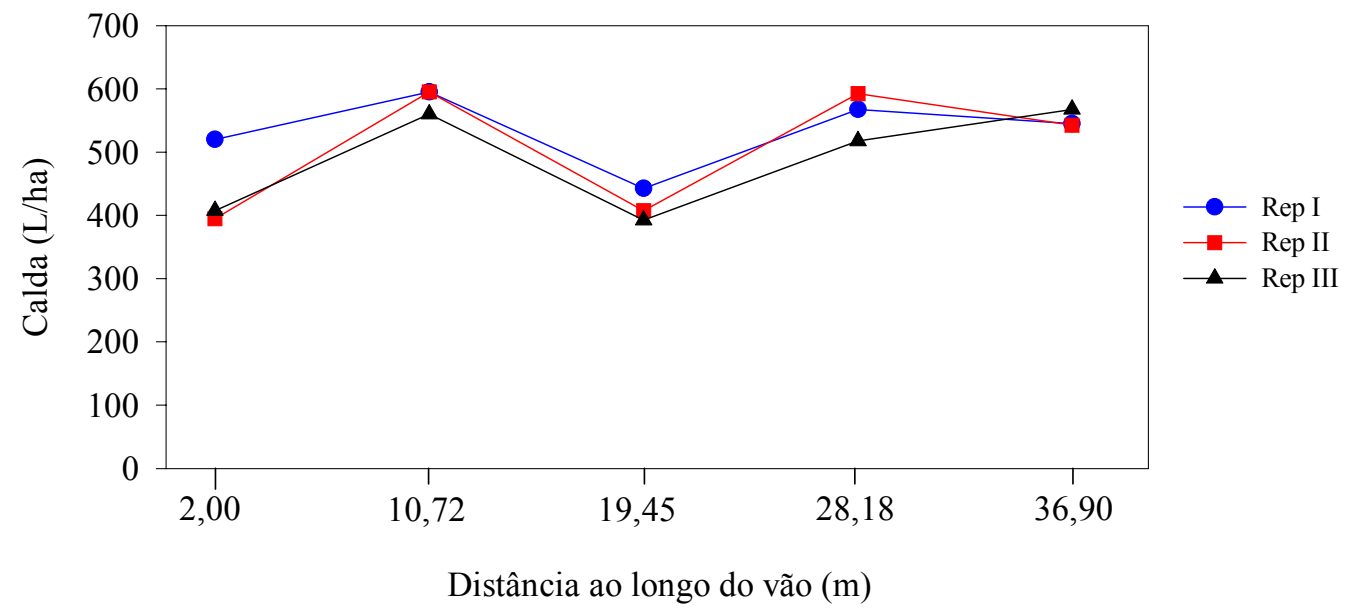

(c)

Figura 29 - Volumes de calda determinados para tempos ligados e desligados de 0,3/3,0s (a), 0,4/3,0s (b) e 0,5/3,0s (c) nas repetições I, II e III. 


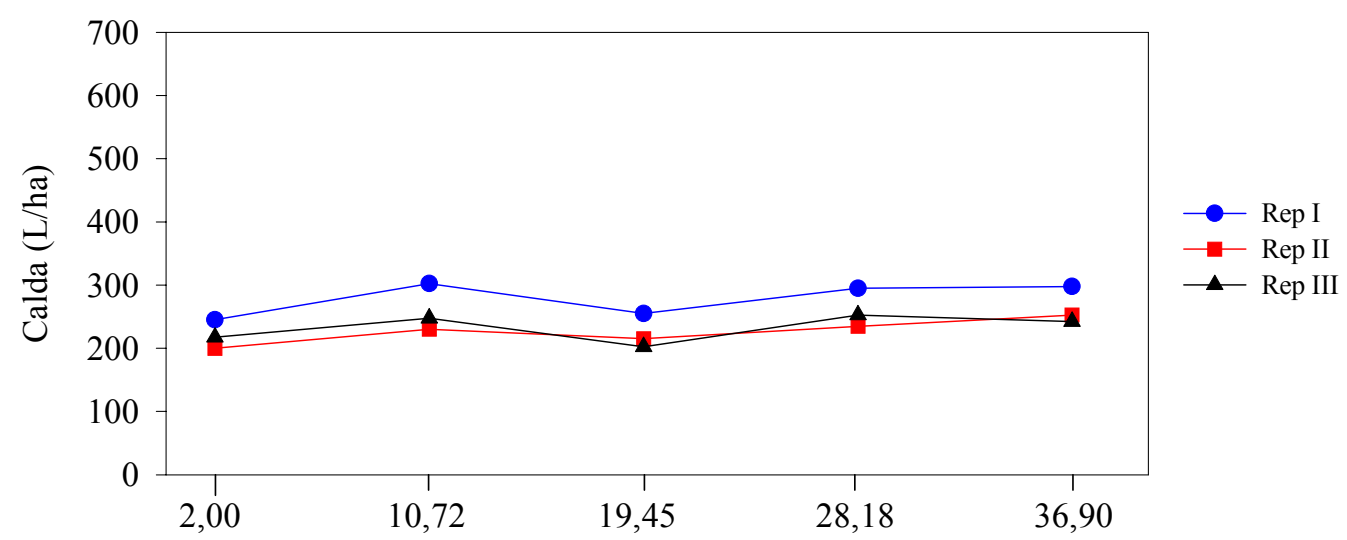

Distância ao longo do vão (m)

(a)

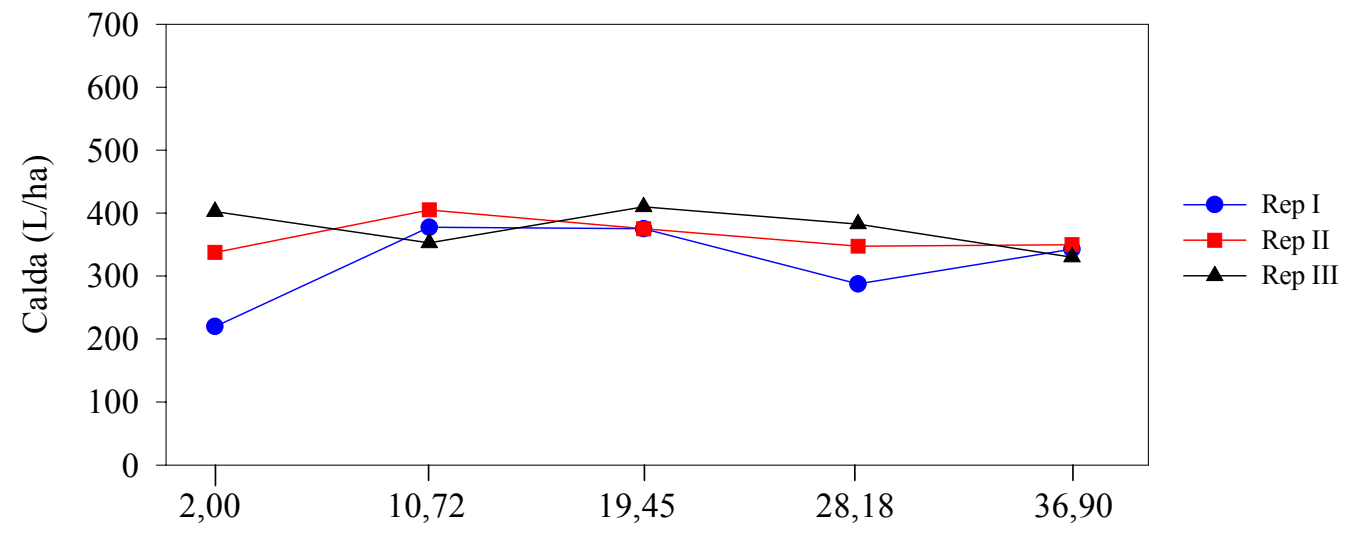

Distância ao longo do vão (m)

(b)

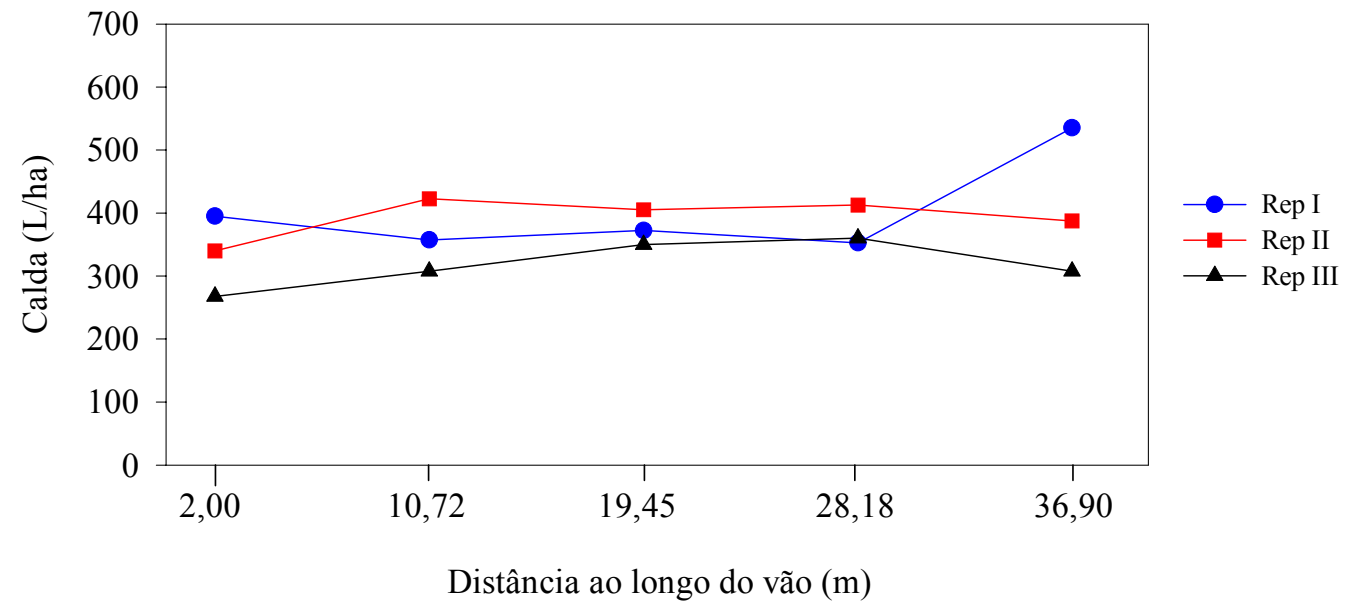

(c)

Figura 30 - Volumes de calda determinados para tempos ligados e desligados de $0,3 / 3,5 \mathrm{~s}$ (a), $0,4 / 3,5 \mathrm{~s}$ (b) e $0,5 / 3,5 \mathrm{~s}$ (c) nas repetições I, II e III. 
$\mathrm{Na}$ Tabela 14 encontram-se resumidas as caldas estimadas e observadas para as diferentes relações de tempo programadas no circuito eletro-eletrônico que gerencia o equipamento. Esclarece-se que as caldas estimadas foram determinadas com base no volume aplicado pelo primeiro emissor, cujo resultado foi apresentado no item 4.5. Nessa tabela também se encontram descritas as diferenças percentuais entre as lâminas estimadas e observadas, sendo a primeira considerada como a que realmente deveria ser aplicada pelo sistema. Também foram sumarizados os valores médios de $\mathrm{CV}$ determinados em cada um dos testes.

Tabela 14. Diferenças percentuais entre as lâminas estimadas e observadas e CV determinados para cada relação de tempos ligado/desligado avaliadas.

\begin{tabular}{ccccccc}
\hline $\begin{array}{c}\text { Tempo } \\
\text { ligado (s) }\end{array}$ & $\begin{array}{c}\text { Tempo } \\
\text { desligado (s) }\end{array}$ & $\begin{array}{c}\text { Redução }^{*} \\
(\%)\end{array}$ & \multicolumn{2}{c}{ Calda (L/ha) } & Diferença & CV \\
\hline 0,3 & 2,5 & 10,71 & 389,11 & 331,5 & 14,8 & 16,3 \\
0,4 & 2,5 & 13,79 & 500,93 & 436,1 & 12,9 & 12,7 \\
0,5 & 2,5 & 16,67 & 605,29 & 543,8 & 10,2 & 12,6 \\
0,3 & 3,0 & 9,09 & 330,16 & 305,2 & 7,6 & 20,0 \\
0,4 & 3,0 & 11,76 & 427,26 & 367,5 & 14,0 & 22,6 \\
0,5 & 3,0 & 14,29 & 518,82 & 509,8 & 1,7 & 15,3 \\
0,3 & 3,5 & 7,89 & 286,71 & 246,0 & 14,2 & 13,0 \\
0,4 & 3,5 & 10,26 & 372,48 & 353,0 & 5,2 & 13,9 \\
0,5 & 3,5 & 12,50 & 453,97 & 371,5 & 18,2 & 16,7 \\
\hline
\end{tabular}

* Decorrente da operação da válvula solenóide (tempo ligado/tempo ligado+tempo desligado).

Pelos resultados apresentados, verifica-se que as lâminas observadas foram inferiores às estimadas. Essas variações podem ser explicadas, possivelmente, por diversas causas, tais como o tempo de resposta hidráulica diferenciado em cada pulso, erro metodológico de coleta e amostragem, possíveis evaporações decorridas após a exposição dos coletores à pulverização, dentre outras. 
Embora todo o sistema tenha sido projetado para realizar aplicações com valores de CV próximos a 8,6\%, verifica-se na Tabela 14 que as análises provenientes dos ensaios de uniformidade de distribuição para os tempos ligado/desligado de $0,4 / 2,5 \mathrm{~s}$, $0,5 / 2,5 \mathrm{~s}, 0,3 / 3,5 \mathrm{~s}$ e $0,4 / 3,5 \mathrm{~s}$ resultaram em coeficientes de variação inferiores a $15 \%$, portanto, de acordo com os relatos de Buchleiter et al.(2001), seriam ainda considerados como adequados para aplicações por meio de equipamentos terrestres.

Os tempos $0,3 / 2,5 \mathrm{~s}, 0,3 / 3,0 \mathrm{~s}, 0,4 / 3,0 \mathrm{~s}, 0,5 / 3,0 \mathrm{~s}$ e $0,5 / 3,5 \mathrm{~s}$ resultaram em coeficientes de variação superiores a 15\% e, em conformidade com Cupery (1987), resultariam em aplicações de qualidade marginal.

Vale esclarecer que a metodologia empregada nas análises de uniformidade foi idealizada neste trabalho, e, embora tenha sido aplicada criteriosamente, pode ter influenciado nos resultados obtidos.

\subsection{Dimensionamento empregando o programa computacional}

Na primeira tela do programa são apresentados o título do trabalho e os autores do programa (Figura 31). No menu principal, localizado na parte superior dessa tela, deve-se escolher o arquivo a ser aberto, caso exista, ou o nome a ser dado a um novo arquivo. Além disso, existem outros três menus que permitem finalizar a execução do programa (Finaliza), obter informações detalhadas sobre este (Ajuda) e os endereços e locais de trabalho dos autores (Autores).

Após a escolha entre a abertura de um arquivo já existente ou a criação de um novo, o programa exibe uma segunda tela onde devem ser fornecidos os dados de entrada para o dimensionamento (Figura 32). Nessa tela, os dados utilizados no dimensionamento da barra de pulverização desenvolvida neste trabalho são apresentados como padrão.

Caso seja necessário alterar as informações relativas ao número de tipos de emissores ou de vãos do pivô a serem empregados no dimensionamento, basta que sejam modificadas as configurações constantes no arquivo criado automaticamente com o mesmo nome escolhido para o dimensionamento. Esse arquivo encontra-se armazenado 
na pasta "Project", em "Arquivos de programa", e deve ser trabalhado por meio de editores de texto capazes de executar tais extensões, como por exemplo o WordPad (Bloco de Notas) do pacote Office.

L.A.A. VILELA, T.A. BOTREL, D. DOURADO NETO. SPPC. צ. 1.00. 2002. Árquivo Calcula Finaliza Aiuda Autores Restrições

\section{Dimensionamento de um sistema de pulverização acoplável a pivô central}

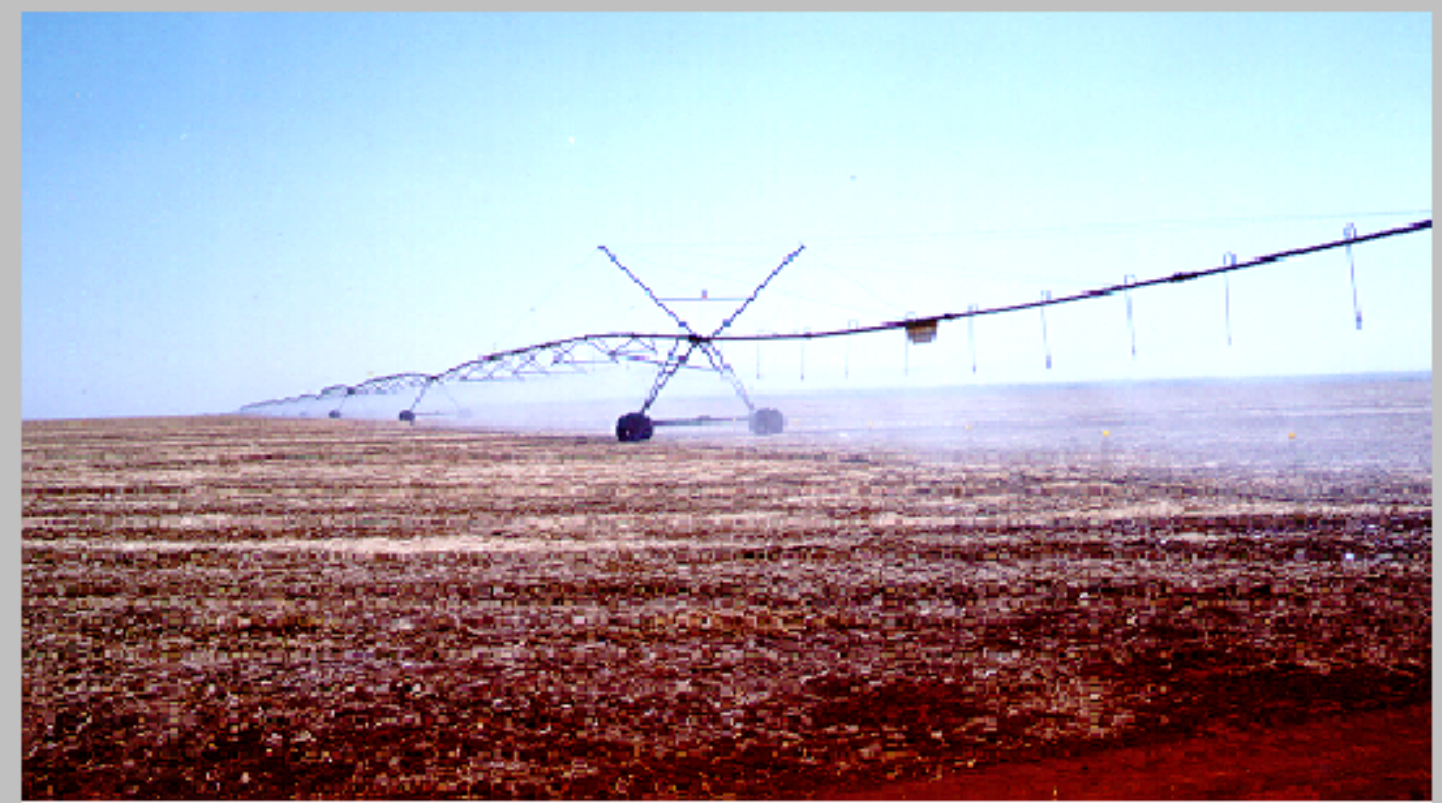

Abra um arquivo [*SPC] para iniciar o dimensionamento

Figura 31 - Tela principal do programa SPPC. 
L.A.A. VILELA, T.A. BOTREL, D. DOURADO NETO. SPPC. צ. 1.00. 2002.

Ärquivo Calcula Finaliza Aiunda Autores Restrições

\section{Dimensionamento de um sistema de pulverização acoplável a pivô central}

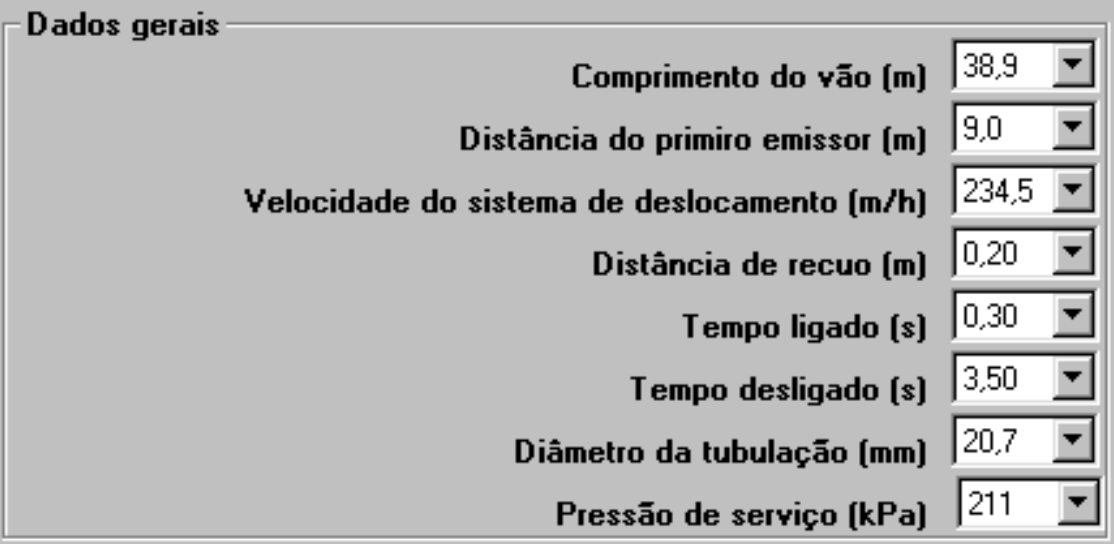

Emissores disponíveis

\begin{tabular}{|c|c|c|c|c|c|}
\hline Id & Qn (L/h) & emax (m) & $k$ & $x$ & Cor \\
\hline 1 & 5,32 & 0,27 & 0,39 & 0,49 & Azul \\
\hline 2 & 10,35 & 0,41 & 0,93 & 0,45 & Larania \\
\hline 3 & 15,89 & 0,42 & 1,34 & 0,46 Vermelha \\
\hline 4 & 19,73 & 0,50 & 1,66 & 0,46 & Preta \\
\hline
\end{tabular}

Pivô central Raio: $727,2 \mathrm{~m}$ Area: 166,1 ha

\begin{tabular}{|c|c|c|}
\hline Vão & $C[\mathrm{~m}]$ & \\
\hline 1 & 38,9 & \\
\hline 2 & 38,9 & \\
\hline 3 & 38,9 & \\
\hline 4 & 38,9 & \\
\hline 5 & 38,9 & \\
\hline 6 & 38,9 & \\
\hline 7 & 38,9 \\
\hline 8 & 38,9 \\
\hline 9 & 38,9 \\
\hline 10 & 38,9 \\
\hline 11 & 38,9 \\
\hline 12 & 38,9 \\
\hline 13 & 38,9 \\
\hline 14 & 38,9 \\
\hline 15 & 38,9 \\
\hline 16 & 38,9 \\
\hline 17 & \\
\hline
\end{tabular}

Arquivo: C:VRQUIVOS DE PROGRAMAS\PROJECT1\TESE.SPC

Figura 32 - Tela de entrada dos dados a serem empregados no dimensionamento da barra de pulverização pelo programa SPPC.

Após a informação dos dados de entrada e clicando-se sobre o menu "Calcula", o programa é executado. Terminada essa fase, uma mensagem comunica se os cálculos foram realizados com sucesso ou não. Caso não existam problemas nos cálculos, a tela de resultados é mostrada (Figura 33). Nessa tela também podem ser visualizados os gráficos da perda de carga em cada um dos trechos que compõe a tubulação, a perda de carga acumulada em toda sua extensão, a linha piezométrica da barra, a vazão de cada um dos emissores que a compõe e a vazão acumulada ao longo da barra. A imagem 
ampliada de cada um desses gráficos pode ser obtida clicando-se sobre o gráfico escolhido.

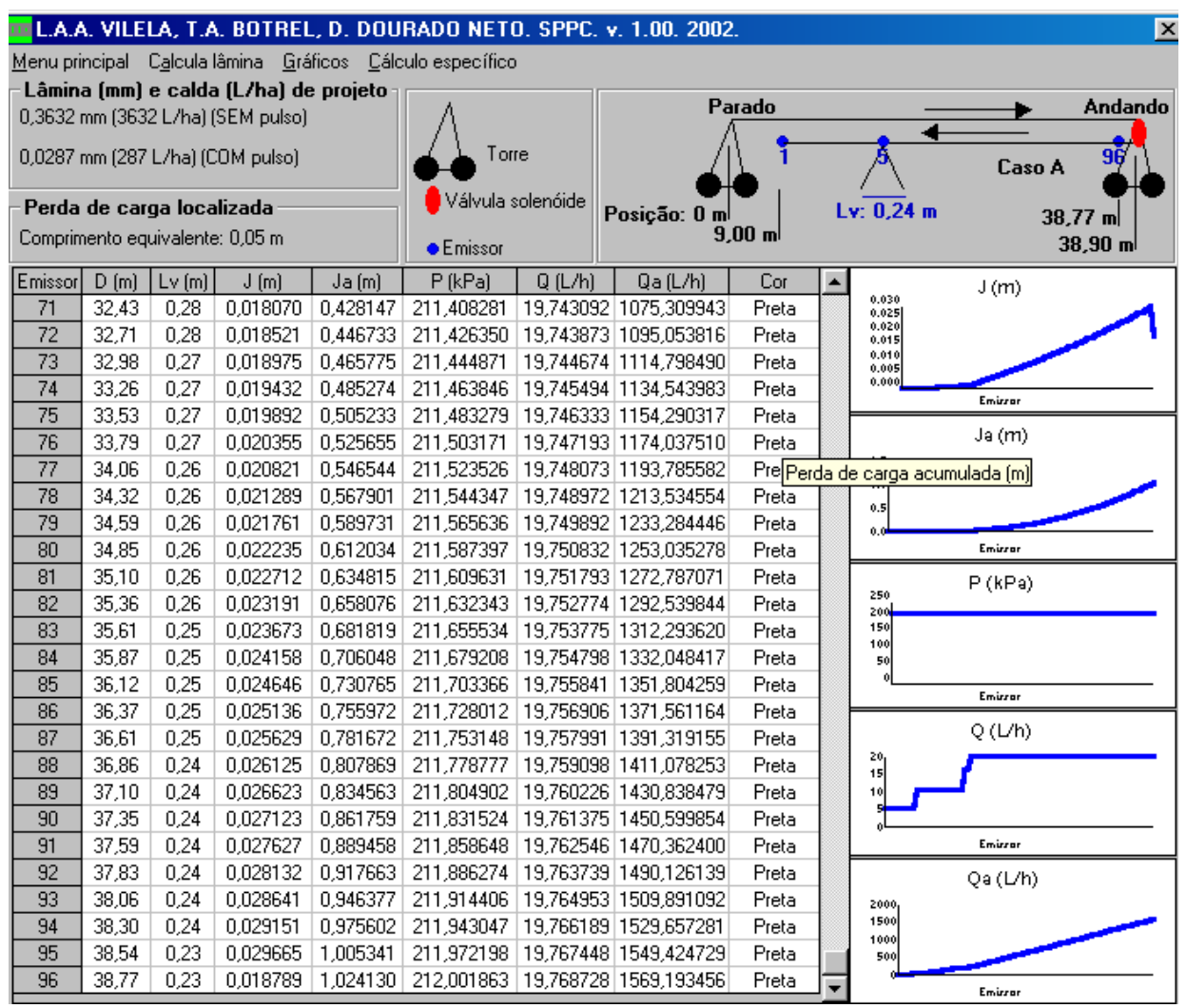

Figura 33 - Tela do programa SPC na qual são apresentados os resultados do dimensionamento da barra de pulverização.

Na parte superior da tela, são apresentados os valores das lâminas e das caldas, na presença ou não de pulsos, evidenciando a redução obtida. Ao lado, é exibido um esquema da metodologia empregada para o dimensionamento de uma das barras do sistema de pulverização.

O fluxograma do programa SPPC é apresentado no Apêndice 3 e a versão executável do mesmo encontra-se no cd-rom anexo a este trabalho.

Os resultados do dimensionamento da barra de pulverização por meio do programa computacional SPPC encontram-se no Anexo D. 
Na Tabela 15 é apresentado um resumo dos resultados do dimensionamento realizado por meio da planilha eletrônica, o qual foi empregado para a construção de cada barra de pulverização (Tabela 12) e os obtidos mediante o programa SPPC (Anexo D).

Tabela 15. Resumo dos resultados do dimensionamento da barra de pulverização realizado por meio da planilha eletrônica e do programa computacional SPPC.

\begin{tabular}{lrr}
\hline Item & Planilha eletrônica & Programa \\
\hline Número de bocais azuis & 10 & 11 \\
Número de bocais laranja & 17 & 17 \\
Número de bocais vermelhos & 2 & 2 \\
Número de bocais pretos & 66 & 66 \\
Número total de bocais & 95 & 96 \\
Perda de carga na barra & $9,99 \mathrm{kPa}$ & $10,00 \mathrm{kPa}$ \\
Vazão total da barra & $1.563,11 \mathrm{~L} / \mathrm{h}$ & $1.569,19 \mathrm{~L} / \mathrm{h}$ \\
Lâmina & $0,3632 \mathrm{~mm}$ & $0,3632 \mathrm{~mm}$ \\
Calda & $287 \mathrm{~L} / \mathrm{ha}$ & $287 \mathrm{~L} / \mathrm{ha}$ \\
Posição do primeiro emissor & $9,00 \mathrm{~m}$ & $9,00 \mathrm{~m}$ \\
Posição do último emissor & $38,70 \mathrm{~m}$ & $38,77 \mathrm{~m}$ \\
\hline
\end{tabular}

Nos resultados apresentados na Tabela 15 observa-se que praticamente não existem diferenças entre os resultados provenientes da planilha eletrônica e do programa SPPC. Com exceção da cor azul, o número de bocais empregados foi idêntico. Revendose a planilha eletrônica, verificou-se que o número de bocais azul deveria ser exatamente o mesmo, entretanto, arredondamentos no valor da largura da faixa de deposição, que foram feitos com objetivo de facilitar a visualização planilha durante os cálculos, geraram diferenças muito pequenas no espaçamento entre os emissores, as quais foram desprezadas no momento da substituição dos emissores de cor azul pelos laranja, o que levou a um menor número de unidades do primeiro modelo. No programa SPPC, todos 
os cálculos, inclusive os testes condicionais, são realizados com dupla precisão (16 casas decimais), e a escolha dos emissores segue exatamente aos critérios da programação. Quanto ao posicionamento dos bocais, verifica-se que o último emissor foi locado pelo programa uma distância de $38,77 \mathrm{~m}$ do início do vão, enquanto deveria se encontrar a uma distância inferior a 38,70m (comprimento total do vão subtraído da distância de recuo) para uma distância de recuo de $0,20 \mathrm{~m}$. Isso pode ser explicado pelo fato de que o teste condicional empregado para a finalização do cálculo da barra $\left(P_{i}>L_{j}-D_{r}\right)$ permite que um único emissor seja locado dentro da faixa de recuo, momento em que cessam os cálculos e ocorre apresentação dos resultados pelo programa (condição de término dos cálculos pelo programa).

\subsection{Considerações finais}

\subsubsection{Consumo de energia}

O consumo energético basicamente envolve a adução de água para pulverização até o centro do pivô, o sistema de pressurização e os motorredutores, além da alimentação de outros componentes nos quais o consumo é pouco significante, tais como os circuitos responsáveis pela intermitência e a própria válvula solenóide. Comparativamente aos pulverizadores terrestres ou aéreos, esse consumo energético é muitas vezes inferior em razão das características do sistema de pulverização e de deslocamento do pivô central.

\subsubsection{Custo do equipamento}

O custo dos materiais para a fabricação das barras de pulverização empregadas no protótipo desenvolvido neste trabalho foi de R $\$ 2.163,90$ (US\$1,045.56) (Anexo E). Nesse custo não foram contabilizados o sistema de bombeamento e as tubulações para transporte da calda até as barras de pulverização, embora se acredite que uma estimativa desses valores da ordem de $20 \%$ seja suficiente para a aquisição de tais componentes. 
Dessa forma, a instalação do sistema em um único vão do pivô, com as mesmas características do utilizado neste trabalho, chegaria a aproximadamente $\mathrm{R} \$ 2.600,00$ (US\$1,040.00).

Ainda que o custo dos componentes do sistema seja relativamente elevado, para culturas de alto valor econômico, sujeitas a injúrias devido à entrada de pulverizadores na área irrigada, o emprego de sistema de pulverização deste tipo tornar-se-ía ainda mais interessante devido às razões técnicas e econômicas envolvidas no processo de produção.

\subsubsection{Risco de uso do equipamento}

Os ensaios realizados com o equipamento foram feitos na ausência de qualquer tipo de formulação química. Por esse motivo, algumas dúvidas somente poderão ser elucidadas após a realização de extensivas avaliações de campo com tais produtos, o que seria objeto de outro estudo.

Apesar da constante preocupação em utilizar componentes resistentes à ação de produtos químicos, nada pode ser afirmado quanto à durabilidade de certos componentes, particularmente os que constituem o conjunto de emissão, em razão de serem produtos comercializados para atenderem a outras finalidades. Da mesma forma que ocorre em certos tipos de pontas de pulverização, o envelhecimento natural e um possível desgaste acelerado, proveniente da ação de produtos químicos associado às altas velocidades de escoamento do líquido, poderiam alterar tanto o funcionamento das válvulas antigotas como a vazão dos emissores, comprometendo a qualidade da aplicação.

Também existem dúvidas com relação à durabilidade das válvulas solenóides quando submetidas a diversos ciclos de abertura e fechamento ao longo do tempo, embora sejam produtos usualmente empregados em pulverizadores agrícolas, porém, sob menor freqüência de operação.

O protótipo não apresentou qualquer tipo de problema durante os ensaios e testes a que foi submetido. Entretanto, sugere-se que outros estudos também devam ser 
conduzidos no sentido de verificar a possibilidade de ocorrência de entupimentos quando o sistema de pulverização for empregado para aplicação de produtos químicos comerciais.

O dispositivo para controle da altura da barra de pulverização e os componentes eletro-eletrônicos atenderam plenamente às necessidades do sistema de pulverização.

Quanto às condições topográficas, o equipamento, da maneira em que se encontra deve ser utilizado preferencialmente em terreno plano ou pouco inclinado, que apresente um mínimo de estruturas para controle de erosão, as quais poderiam interferir na altura de aplicação, e, conseqüentemente, na qualidade dessa. Por outro lado, o sistema de levantamento do conjunto tensionador poderia ser modificado e automatizado, possibilitando a utilização do equipamento em condições de relevo irregular ou acidentado.

Existe a limitação técnica de emprego do equipamento nas áreas irrigadas por canhões hidráulicos instalados na extremidade do pivô.

\subsubsection{Injeção de produtos no sistema de pulverização}

A injeção dos produtos químicos no sistema de pulverização pode ser feita conforme procedimentos descritos por Garvey (1981), Summer et al. (1997) ou Pereira (2001).

\subsubsection{Barra de pulverização da tubulação em balanço}

$\mathrm{Na}$ tubulação em balanço ocorrem duas variantes de velocidade em virtude da movimentação das duas últimas torres de sustentação que o antecede: (i) a penúltima torre encontra-se parada e a última em movimento e; (ii) ambas torres apresentam movimento. A primeira situação leva a distribuições de velocidade ao longo do último vão e do balanço da seguinte forma: no ponto situado exatamente sobre a penúltima torre de sustentação a velocidade é nula, a qual aumenta linearmente. No exato local onde se encontra a última torre, atinge o valor que corresponde à velocidade de 
deslocamento da mesma. A velocidade de deslocamento atinge um valor máximo na extremidade final da tubulação em balanço. Dessa forma, os emissores a serem instalados em uma das duas barras de pulverização localizadas no balanço devem ser dimensionados para atender a essa variação de velocidade, sendo um prolongamento de uma das barra localizada no último vão do pivô. Os espaçamentos entre os emissores dessa barra diminuem do início para o final da mesma, à medida que os bocais se tornam mais distantes do centro do pivô, conforme a metodologia apresentada no item 3.8.4. Essa barra seria acionada somente quando a última torre estivesse em movimento e a anterior parada, devendo ser equipada com duas válvulas solenóides, instaladas em série no sentido do fluxo do interior da tubulação,. A primeira válvula, acionada pelo circuito eletro-eletrônico da última torre de sustentação, seria responsável pela intermitência dessa barra. A segunda válvula, ligada ao circuito eletro-eletrônico da penúltima torre, permitiria a passagem do fluxo hidráulico sempre que houvesse movimento dessa torre. $\mathrm{Na}$ segunda situação de distribuição de velocidades, todos os pontos da tubulação em balanço, assim como do último vão, apresentariam velocidades de deslocamento constantes. Os emissores deveriam ser igualmente espaçados sobre a segunda barra, possibilitando que toda área pulverizada recebesse o mesmo volume por unidade de área. Essa barra seria acionada somente nos instantes em que existisse movimento simultâneo nas duas últimas torres de sustentação.

O programa computacional SPPC contempla a metodologia de cálculo descrita anteriormente para a tubulação em balanço. Também atende ao dimensionamento das barras de pulverização para os modelos de pivô disponíveis no mercado.

\subsubsection{Inovações tecnológicas}

As principais inovações tecnológicas do protótipo desenvolvido neste trabalho, quando comparado aos sistemas de pulverização para pivô central relatados na literatura são: (i) o sistema é composto de duas barras de pulverização, o que leva à compensação das variantes de velocidade que ocorrem ao longo da torre do pivô, possibilitando aplicações uniformes em toda a área a ser tratada; (ii) o sistema é capaz de aplicar 
reduzidas quantidades de caldas, próximas aos valores recomendados pelos fabricantes de defensivos químicos para aplicações terrestres, dada a intermitência na aplicação, o que possibilita que todo o ingrediente ativo permaneça retido no alvo da pulverização, garantindo a máxima eficiência de controle do produto (a aplicação de herbicida em pósemergência foi tomada como referência); (iii) o tamanho e a distribuição das gotas foram avaliados de acordo com técnicas empregadas na pulverização, os quais geralmente não tem sido relatados nos trabalhos sobre sistemas de pulverização acopláveis a pivô central; (iv) as barras de pulverização são intercambiáveis para vãos de um pivô que apresentem o mesmo comprimento e a mesma velocidade de deslocamento, o que facilita a montagem do sistema no equipamento de irrigação (essa comprovação pode ser verificada por meio do programa computacional SPPC) e, (v) o programa computacional SPPC obedece toda a metodologia descrita neste trabalho, possibilitando dimensionar barras de pulverização para atender aos diferentes modelos de pivôs centrais disponíveis no mercado. 


\section{CONCLUSÕES}

Para as condições em que este trabalho foi realizado, com base nos equipamentos utilizados e na avaliação do sistema de pulverização, é possível concluir que a metodologia proposta se presta para o dimensionamento de sistemas de pulverização para pivô central, sendo que:

a) o sistema é capaz de aplicar um volume mínimo de pulverização por unidade de área de 246L/ha, apropriado para diversos tipos de formulações;

b) o diâmetro mediano volumétrico e numérico médio do espectro de gotas foram de 126,30 e 98,25 $\mu \mathrm{m}$, respectivamente, atendendo às recomendações técnicas para aplicação de defensivos agrícolas;

c) o coeficiente de dispersão médio de 1,29 permite classificar o espectro de gotas produzidas ao longo da barra de pulverização como uniforme;

d) as análises provenientes dos ensaios de uniformidade de distribuição para os tempos ligado/desligado da válvula solenóide de $0,4 / 2,5 \mathrm{~s}, 0,5 / 2,5 \mathrm{~s}, 0,3 / 3,5 \mathrm{~s}$ e $0,4 / 3,5 \mathrm{~s}$ resultaram em valores de coeficientes de variação das caldas aplicadas inferiores a 15\%, podendo-se considerar aceitáveis para pulverizações por meio terrestre;

e) os tempos ligado/desligado da válvula solenóide de 0,3/2,5s, 0,3/3,0s, $0,4 / 3,0 \mathrm{~s}, 0,5 / 3,0$ s e $0,5 / 3,5 \mathrm{~s}$ resultaram em coeficientes de variação superiores a $15 \%$ e, portanto, são desaconselhados;

f) o dispositivo de ajuste de altura da barra de pulverização permite que essa seja: ( $i$ ) automatizada, mediante inclusão de dispositivos extras no sistema e; (ii) posicionada a diferentes distâncias verticais compreendidas entre o eixo 
principal da torre de sustentação (motorredutor) e aproximadamente $15 \mathrm{~cm}$ abaixo da altura mínima do vão, de maneira a manter uma distância do alvo de aproximadamente $50 \mathrm{~cm}$;

g) o microcontrolador Basic Step e o circuito eletro-eletrônico possibilitaram sincronizar a operação da válvula solenóide ao movimento do sistema de propulsão do pivô, além de promover a intermitência do sistema de pulverização, o que proporcionou expressiva redução da calda aplicada;

h) o programa computacional desenvolvido para o dimensionamento de

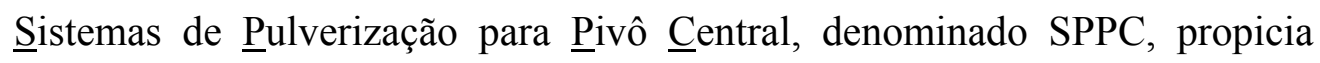
fazer o dimensionamento hidráulico do sistema de pulverização, de acordo com a metodologia proposta, para diferentes modelos de pivôs centrais. 
ANEXOS 


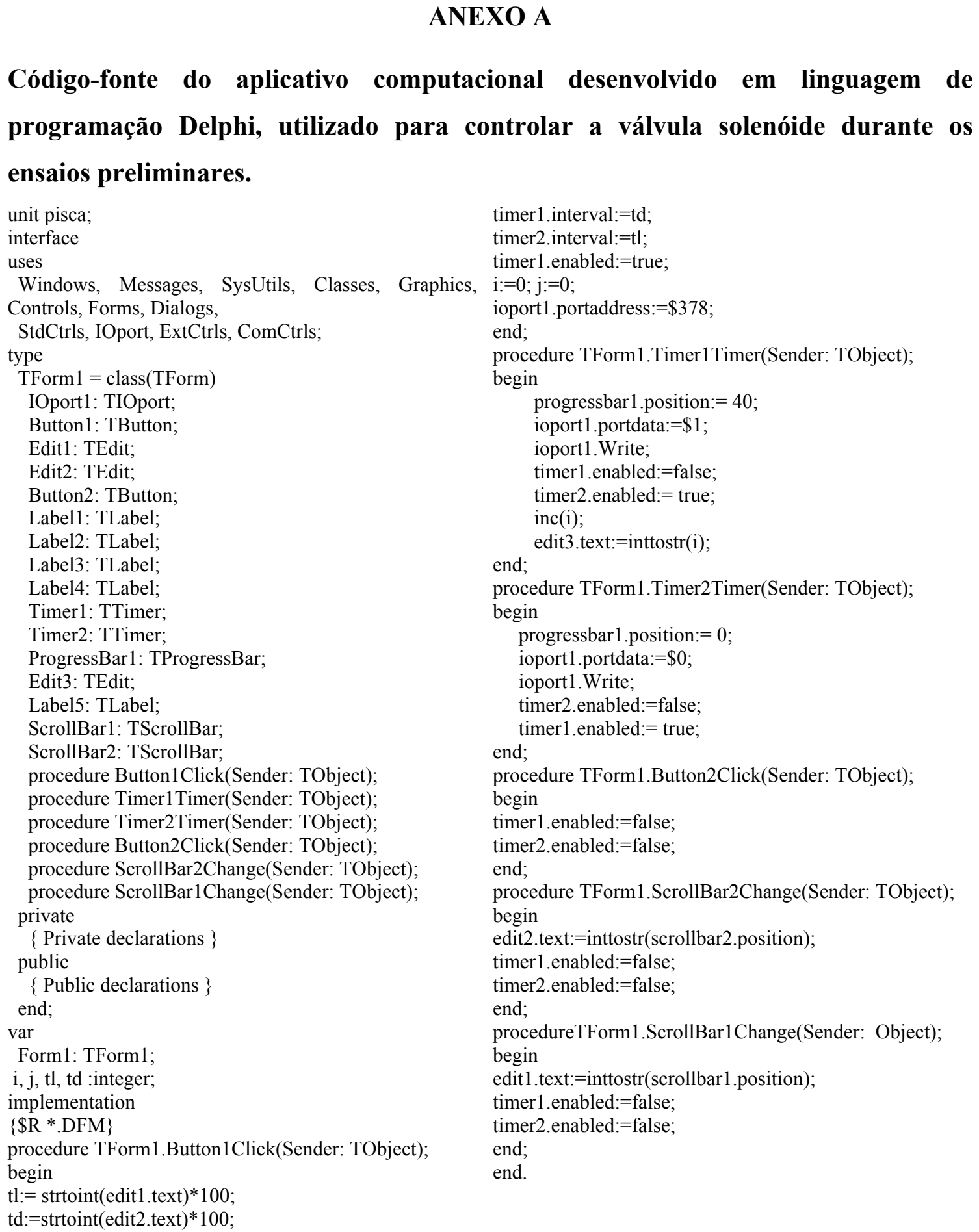

Obs.: O programa acima, na forma de arquivo executável, encontra-se no CD-Rom anexo a este trabalho. No caso de nova digitalização, deve-se instalar previamente na plataforma Delphi o componente IOport, também disponível no referido CD-Rom. 


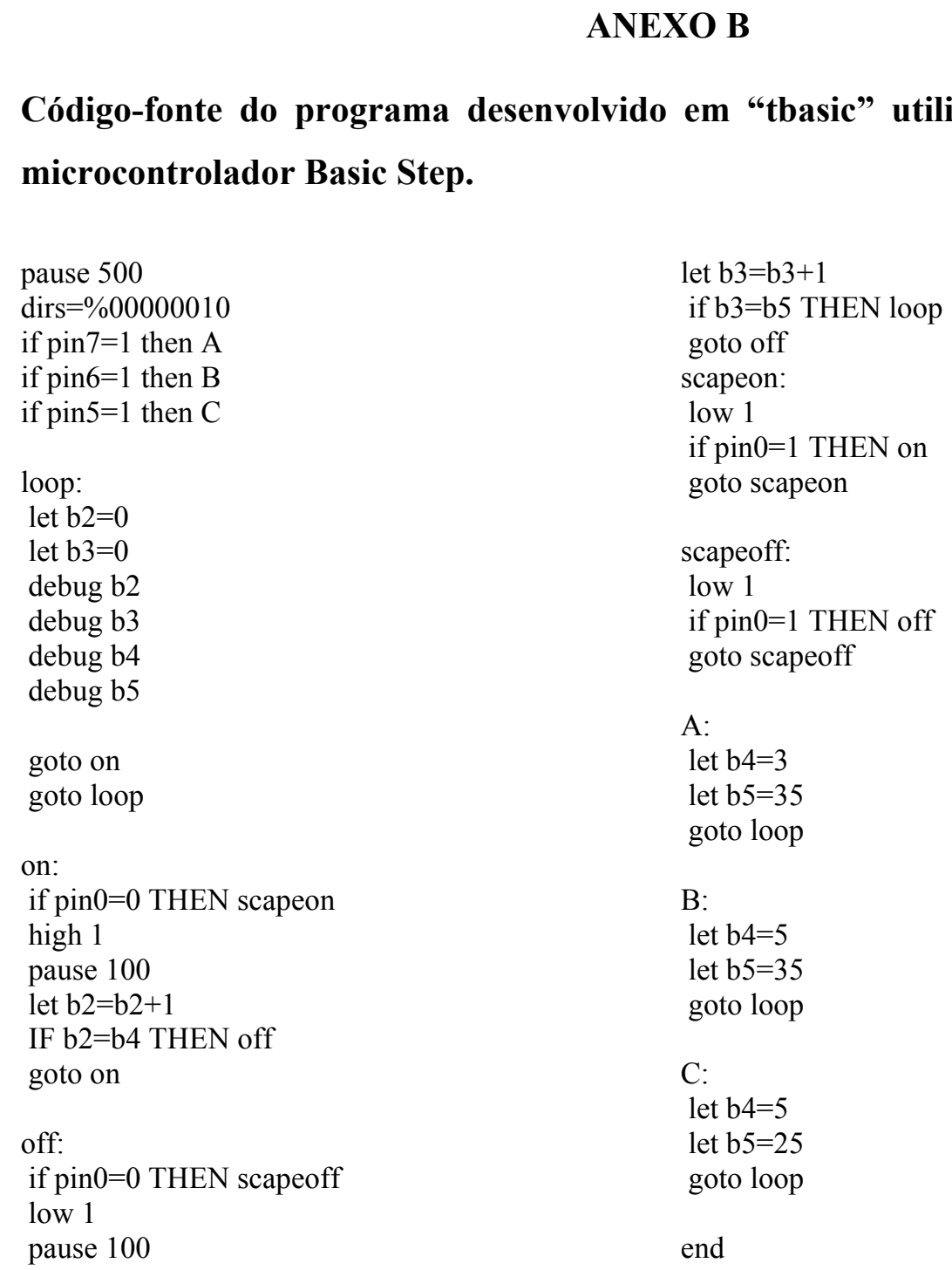

Obs.: a) tanto o programa listado acima como o software emulador do microcontrolador Basic Step encontram-se no CD-Rom disponibilizado junto a este trabalho;

b) no Anexo $\mathrm{C}$ encontram-se relacionadas às configurações dos pinos do microcontrolador para atender as três diferentes lâminas programadas. 


\section{ANEXO C}

Configuração dos pinos do microcontrolador, respectivos tempos ligado e desligado das válvulas solenóides e correspondentes taxas de aplicação.

\begin{tabular}{cccc}
\hline $\begin{array}{c}\text { Pino do microcontrolador } \\
\text { em nível alto }\end{array}$ & \multicolumn{2}{c}{ Tempo (s) } & $\begin{array}{c}\text { Taxa de aplicação } \\
(\text { L/ha })\end{array}$ \\
\cline { 2 - 3 } & Ligado & Desligado & 543,8 \\
6 & 5 & 25 & 371,5 \\
7 & 5 & 35 & 246,0 \\
\hline
\end{tabular}


ANEXO D

Resultados do dimensionamento da barra de pulverização por meio do programa computacional.

\begin{tabular}{|c|c|c|c|c|c|}
\hline Emissor & Posição (m) & Vazão (L/h) & Largura $(\mathrm{m})$ & Perda de Carga $(\mathrm{m})$ & Pressão de serviço $(\mathrm{kPa})$ \\
\hline 1 & 9,00 & 5,32498267 & 0,270 & 0,00000162 & 211,00000000 \\
\hline 2 & 9,27 & 5,32498269 & 0,262 & 0,00000531 & 211,00000162 \\
\hline 3 & 9,53 & 5,32498275 & 0,255 & 0,00001055 & 211,00000692 \\
\hline 4 & 9,78 & 5,32498288 & 0,249 & 0,00001708 & 211,00001747 \\
\hline 5 & 10,02 & 5,32498309 & 0,243 & 0,00002473 & 211,00003455 \\
\hline 6 & 10,26 & 5,32498340 & 0,237 & 0,00003337 & 211,00005928 \\
\hline 7 & 10,50 & 5,32498381 & 0,232 & 0,00004291 & 211,00009265 \\
\hline 8 & 10,73 & 5,32498434 & 0,227 & 0,00005327 & 211,00013557 \\
\hline 9 & 10,95 & 5,32498500 & 0,222 & 0,00006437 & 211,00018884 \\
\hline 10 & 11,17 & 5,32498579 & 0,218 & 0,00007617 & 211,00025321 \\
\hline 11 & 11,39 & 5,32498673 & 0,214 & 0,00012196 & 211,00032938 \\
\hline 12 & 11,70 & 10,34853990 & 0,404 & 0,00020252 & 211,00045134 \\
\hline 13 & 12,09 & 10,34854436 & 0,391 & 0,00025132 & 211,00065386 \\
\hline 14 & 12,48 & 10,34854991 & 0,379 & 0,00030320 & 211,00090518 \\
\hline 15 & 12,85 & 10,34855659 & 0,368 & 0,00035788 & 211,00120838 \\
\hline 16 & 13,21 & 10,34856449 & 0,358 & 0,00041513 & 211,00156625 \\
\hline 17 & 13,57 & 10,34857364 & 0,348 & 0,00047477 & 211,00198138 \\
\hline 18 & 13,91 & 10,34858412 & 0,340 & 0,00053664 & 211,00245615 \\
\hline 19 & 14,25 & 10,34859595 & 0,332 & 0,00060061 & 211,00299280 \\
\hline 20 & 14,57 & 10,34860920 & 0,324 & 0,00066655 & 211,00359340 \\
\hline 21 & 14,90 & 10,34862390 & 0,317 & 0,00073437 & 211,00425995 \\
\hline 22 & 15,21 & 10,34864010 & 0,311 & 0,00080397 & 211,00499432 \\
\hline 23 & 15,52 & 10,34865783 & 0,305 & 0,00087528 & 211,00579830 \\
\hline 24 & 15,82 & 10,34867713 & 0,299 & 0,00094823 & 211,00667358 \\
\hline 25 & 16,12 & 10,34869805 & 0,293 & 0,00102275 & 211,00762181 \\
\hline 26 & 16,41 & 10,34872060 & 0,288 & 0,00109878 & 211,00864456 \\
\hline 27 & 16,69 & 10,34874484 & 0,283 & 0,00117628 & 211,00974334 \\
\hline 28 & 16,97 & 10,34877078 & 0,279 & 0,00153667 & 211,01091962 \\
\hline 29 & 17,32 & 15,88783636 & 0,419 & 0,00200815 & 211,01245629 \\
\hline 30 & 17,74 & 15,88790622 & 0,409 & 0,00242187 & 211,01446444 \\
\hline 31 & 18,19 & 19,72616776 & 0,495 & 0,00294591 & 211,01688631 \\
\hline 32 & 18,68 & 19,72629521 & 0,482 & 0,00323350 & 211,01983222 \\
\hline 33 & 19,15 & 19,72643510 & 0,470 & 0,00352762 & 211,02306572 \\
\hline 34 & 19,62 & 19,72658772 & 0,459 & 0,00382800 & 211,02659334 \\
\hline 35 & 20,07 & 19,72675332 & 0,449 & 0,00413436 & 211,03042134 \\
\hline 36 & 20,52 & 19,72693218 & 0,439 & 0,00444648 & 211,03455570 \\
\hline 37 & 20,95 & 19,72712454 & 0,430 & 0,00476416 & 211,03900218 \\
\hline 38 & 21,38 & 19,72733064 & 0,422 & 0,00508719 & 211,04376634 \\
\hline 39 & 21,79 & 19,72755071 & 0,413 & 0,00541542 & 211,04885353 \\
\hline 40 & 22,20 & 19,72778498 & 0,406 & 0,00574869 & 211,05426895 \\
\hline 41 & 22,61 & 19,72803366 & 0,399 & 0,00608685 & 211,06001764 \\
\hline 42 & 23,00 & 19,72829697 & 0,392 & 0,00642976 & 211,06610449 \\
\hline 43 & 23,39 & 19,72857510 & 0,385 & 0,00677732 & 211,07253425 \\
\hline 44 & 23,77 & 19,72886827 & 0,379 & 0,00712939 & 211,07931157 \\
\hline 45 & 24,15 & 19,72917666 & 0,373 & 0,00748589 & 211,08644097 \\
\hline 46 & 24,52 & 19,72950046 & 0,368 & 0,00784670 & 211,09392685 \\
\hline 47 & 24,88 & 19,72983986 & 0,362 & 0,00821173 & 211,10177355 \\
\hline 48 & 25,24 & 19,73019505 & 0,357 & 0,00858091 & 211,10998529 \\
\hline 49 & 25,60 & 19,73056619 & 0,352 & 0,00895413 & 211,11856619 \\
\hline 50 & 25,95 & 19,73095347 & 0,347 & 0,00933134 & 211,12752032 \\
\hline 51 & 26,29 & 19,73135706 & 0,343 & 0,00971245 & 211,13685166 \\
\hline 52 & 26,63 & 19,73177712 & 0,338 & 0,01009740 & 211,14656412 \\
\hline 53 & 26,97 & 19,73221381 & 0,334 & 0,01048612 & 211,15666152 \\
\hline 54 & 27,30 & 19,73266731 & 0,330 & 0,01087855 & 211,16714764 \\
\hline 55 & 27,63 & 19,73313776 & 0,326 & 0,01127463 & 211,17802619 \\
\hline
\end{tabular}




\section{ANEXO D}

\section{Resultados do dimensionamento da barra de pulverização por meio do programa} computacional.

\begin{tabular}{|c|c|c|c|c|c|}
\hline Emissor & Posição (m) & Vazão (L/h) & Largura $(\mathrm{m})$ & Perda de Carga (m) & Pressão de serviço $(\mathrm{kPa})$ \\
\hline 56 & 27,95 & 19,73362533 & 0,322 & 0,01167431 & 211,18930082 \\
\hline 57 & 28,27 & 19,73413017 & 0,319 & 0,01207752 & 211,20097512 \\
\hline 58 & 28,59 & 19,73465243 & 0,315 & 0,01248423 & 211,21305265 \\
\hline 59 & 28,90 & 19,73519226 & 0,312 & 0,01289438 & 211,22553688 \\
\hline 60 & 29,22 & 19,73574981 & 0,309 & 0,01330793 & 211,23843126 \\
\hline 61 & 29,52 & 19,73632522 & 0,305 & 0,01372482 & 211,25173918 \\
\hline 62 & 29,83 & 19,73691863 & 0,302 & 0,01414503 & 211,26546400 \\
\hline 63 & 30,13 & 19,73753020 & 0,299 & 0,01456850 & 211,27960903 \\
\hline 64 & 30,42 & 19,73816004 & 0,296 & 0,01499520 & 211,29417753 \\
\hline 65 & 30,72 & 19,73880831 & 0,293 & 0,01542509 & 211,30917273 \\
\hline 66 & 31,01 & 19,73947514 & 0,291 & 0,01585814 & 211,32459783 \\
\hline 67 & 31,30 & 19,74016067 & 0,288 & 0,01629431 & 211,34045597 \\
\hline 68 & 31,59 & 19,74086502 & 0,285 & 0,01673357 & 211,35675028 \\
\hline 69 & 31,87 & 19,74158833 & 0,283 & 0,01717588 & 211,37348385 \\
\hline 70 & 32,15 & 19,74233072 & 0,280 & 0,01762121 & 211,39065973 \\
\hline 71 & 32,43 & 19,74309233 & 0,278 & 0,01806954 & 211,40828094 \\
\hline 72 & 32,71 & 19,74387328 & 0,276 & 0,01852083 & 211,42635048 \\
\hline 73 & 32,98 & 19,74467370 & 0,273 & 0,01897506 & 211,44487131 \\
\hline 74 & 33,26 & 19,74549371 & 0,271 & 0,01943220 & 211,46384637 \\
\hline 75 & 33,53 & 19,74633343 & 0,269 & 0,01989222 & 211,48327857 \\
\hline 76 & 33,79 & 19,74719299 & 0,267 & 0,02035511 & 211,50317079 \\
\hline 77 & 34,06 & 19,74807251 & 0,265 & 0,02082082 & 211,52352590 \\
\hline 78 & 34,32 & 19,74897210 & 0,263 & 0,02128935 & 211,54434672 \\
\hline 79 & 34,59 & 19,74989189 & 0,261 & 0,02176067 & 211,56563607 \\
\hline 80 & 34,85 & 19,75083198 & 0,259 & 0,02223475 & 211,58739674 \\
\hline 81 & 35,10 & 19,75179251 & 0,257 & 0,02271158 & 211,60963149 \\
\hline 82 & 35,36 & 19,75277358 & 0,255 & 0,02319113 & 211,63234307 \\
\hline 83 & 35,61 & 19,75377530 & 0,253 & 0,02367338 & 211,65553419 \\
\hline 84 & 35,87 & 19,75479780 & 0,252 & 0,02415832 & 211,67920757 \\
\hline 85 & 36,12 & 19,75584117 & 0,250 & 0,02464592 & 211,70336589 \\
\hline 86 & 36,37 & 19,75690554 & 0,248 & 0,02513617 & 211,72801181 \\
\hline 87 & 36,61 & 19,75799102 & 0,246 & 0,02562905 & 211,75314799 \\
\hline 88 & 36,86 & 19,75909770 & 0,245 & 0,02612454 & 211,77877704 \\
\hline 89 & 37,10 & 19,76022571 & 0,243 & 0,02662263 & 211,80490158 \\
\hline 90 & 37,35 & 19,76137515 & 0,242 & 0,02712330 & 211,83152421 \\
\hline 91 & 37,59 & 19,76254612 & 0,240 & 0,02762652 & 211,85864751 \\
\hline 92 & 37,83 & 19,76373874 & 0,239 & 0,02813230 & 211,88627403 \\
\hline 93 & 38,06 & 19,76495311 & 0,237 & 0,02864061 & 211,91440633 \\
\hline 94 & 38,30 & 19,76618933 & 0,236 & 0,02915143 & 211,94304693 \\
\hline 95 & 38,54 & 19,76744750 & 0,234 & 0,02966476 & 211,97219836 \\
\hline 96 & 38,77 & 19,76872773 & 0,233 & 0,01878861 & 212,00186312 \\
\hline
\end{tabular}


ANEXO E

\section{Custos dos materiais utilizados na confecção do sistema de pulverização.}

\begin{tabular}{|c|c|c|c|}
\hline Descrição & Quantidade & $\begin{array}{r}\text { Custo unitário } \\
\text { (R\$) }\end{array}$ & $\begin{array}{r}\text { Custo total } \\
\text { (R\$) }\end{array}$ \\
\hline \multicolumn{4}{|l|}{ 1. Materiais hidráulicos } \\
\hline Abraçadeira para tubo $3 / 4 "$ & $04 \mathrm{ud}$ & 1,00 & 4,00 \\
\hline Adaptador p/mangueira $3 / 4 "$ & $02 \mathrm{ud}$ & 0,30 & 0,60 \\
\hline Cap esgoto $150 \mathrm{~mm}$ & $02 \mathrm{ud}$ & 10,50 & 21,00 \\
\hline Conector butterfly treaded $3 / 8$ & 190 ud & 0,55 & 104,50 \\
\hline Emissor Fogger 7800 & 190 ud & 3,30 & 627,00 \\
\hline Luva de redução3/4 x 1/2" & $02 \mathrm{ud}$ & 0,35 & 0,70 \\
\hline Mangueira flexível Peti Rubber 3/4" & $6 \mathrm{~m}$ & 8,00 & 48,00 \\
\hline Niple 3/4" & $02 \mathrm{ud}$ & 0,20 & 0,40 \\
\hline Plug 3/4" & $02 \mathrm{ud}$ & 0,15 & 0,30 \\
\hline Registro pvc tipo globo $3 / 4$ " & $02 \mathrm{ud}$ & 9,90 & 19,80 \\
\hline Tubo pvc roscável 3/4" & $120 \mathrm{~m}$ & 1,75 & 210,00 \\
\hline União pvc 3/4" & $02 \mathrm{ud}$ & 3,00 & 6,00 \\
\hline Válvula antigotas $L . P D$. & 190 ud & 3,03 & 574,75 \\
\hline Válvula solenóide AA144A-1 & $02 \mathrm{ud}$ & 320,00 & 640,00 \\
\hline \multicolumn{4}{|l|}{ 2. Materiais eletro-eletrônicos } \\
\hline Chave seletora tipo "DIP" $\mathrm{c} / 8$ pinos & $2 \mathrm{ud}$ & 3,60 & 7,20 \\
\hline Condutor elétrico duplo $1,0 \mathrm{~mm}^{2}$ & $12 \mathrm{~m}$ & 0,15 & 3,75 \\
\hline Diodo 1N4007 & $12 \mathrm{ud}$ & 0,05 & 0,60 \\
\hline Fita isolante $50 \mathrm{~m}$ & $1 \mathrm{ud}$ & 3,00 & 3,00 \\
\hline Fonte de alimentação $127 \mathrm{~V} / 12 \mathrm{~V}$ x $3 \mathrm{~A}$ & $02 \mathrm{ud}$ & 29,00 & 58,00 \\
\hline Microcontrolador Baisc Step & $02 \mathrm{ud}$ & 35,00 & 70,00 \\
\hline Percloreto de ferro & $500 \mathrm{~mL}$ & 4,00 & 4,00 \\
\hline Placa fenolite $5 \times 10 \mathrm{~cm}$ & $2 \mathrm{ud}$ & 0,80 & 1,60 \\
\hline Rele 5 pinos $250 \mathrm{~V} / 10 \mathrm{~A}$ & $04 \mathrm{ud}$ & 2,50 & 10,00 \\
\hline Resistor $10 \mathrm{~K} \Omega$ & $12 \mathrm{ud}$ & 0,05 & 0,60 \\
\hline Resistor $330 \Omega$ & $02 \mathrm{ud}$ & 0,05 & 0,10 \\
\hline Terminal chato & 04 ud & 0,15 & 0,60 \\
\hline Tomada $250 \mathrm{~V} / 10 \mathrm{~A}$ & $04 \mathrm{ud}$ & 0,75 & 3,00 \\
\hline Tranformador $127 \mathrm{~V} / 12 \mathrm{~V} 200 \mathrm{~mA}$ & $2 \mathrm{ud}$ & 3,80 & 7,60 \\
\hline Transistor BC 548 & 02 ud & 0,15 & 0,30 \\
\hline \multicolumn{4}{|l|}{ 3. Ferragens e afins } \\
\hline Arruelas 5/16" & 30 ud & 0,02 & 0,60 \\
\hline Barra rosqueada $5 / 16 "$ & $4 \mathrm{ud}$ & 1,00 & 4,00 \\
\hline Cabo-de-aço 1/8" & $39 \mathrm{~m}$ & 0,74 & 28,80 \\
\hline Cabo-de-aço 1/4" & $48 \mathrm{~m}$ & 0,24 & 11,50 \\
\hline Cantoneira $3 / 16 \times 1 "$ & $14 \mathrm{~m}$ & 1,50 & 9,00 \\
\hline Catraca para cerca & $1 \mathrm{ud}$ & 4,00 & 4,00 \\
\hline Eletrodo $2.5 \mathrm{~mm}$ & $2 \mathrm{~kg}$ & 4,00 & 8,00 \\
\hline Esticador 5/16" & $2 \mathrm{ud}$ & 2,50 & 5,00 \\
\hline Ferro chato $1 / 8 "$ x $3 / 4 "$ & $6 \mathrm{~m}$ & 1,00 & 6,00 \\
\hline Grampo 1/8" & $18 \mathrm{ud}$ & 0,20 & 11,70 \\
\hline Mola $^{1}$ & $1 \mathrm{ud}$ & - & \\
\hline Parafusos 5/16" & 8 ud & 0,20 & 1,60 \\
\hline Perfil dobrado chapa 16 & $6 \mathrm{~m}$ & 5,00 & 30,00 \\
\hline Porcas 5/16" & $30 \mathrm{ud}$ & 0,05 & 1,50 \\
\hline Rodízio "Stanley" 11/2" & $2 \mathrm{ud}$ & 8,50 & 19,00 \\
\hline Roldanas $30 \mathrm{~mm}$ & $13 \mathrm{ud}$ & 2,00 & 26,00 \\
\hline \multicolumn{4}{|l|}{ 3. Outros } \\
\hline Abraçadeira plástica & $36 \mathrm{ud}$ & 0,10 & 3,60 \\
\hline Aguarrás & $500 \mathrm{~mL}$ & 3,80 & 3,80 \\
\hline Pincel & $1 \mathrm{ud}$ & 0,40 & 0,40 \\
\hline Tinta alumínio & $500 \mathrm{~mL}$ & 12,00 & 12,00 \\
\hline TOTAL GERAL (R\$) & & & $2.613,90^{2}$ \\
\hline
\end{tabular}

${ }^{1}$ Encontrada no ferro-velho da ESALQ, sem condição de informar o preço.

${ }^{2}$ Cotação média da moeda americana na época de aquisição dos materiais: US\$1.00 $=\mathrm{R} \$ 2,50$. 


\section{REFERÊNCIAS BIBLIOGRÁFICAS}

\section{ABLEVISION SISTEMAS COMPUTACIONAIS LTDA. E-sprinkle}

(software). São Carlos: s.d. 1v.

ALMEIDA PINTO, N.C.J.de. Introdução à quimigação. In: COSTA, E.F.; VIEIRA, R.F.; VIANA, P.A. Aplicação de produtos químicos e biológicos via água de irrigação. Brasília: EMBRAPA, SPI, 1994. cap.9, p.229-248.

AZEVEDO NETTO, J.M. de; ALVAREZ, G.A. Manual de hidráulica. 6.ed. São Paulo: Edgar Blücher, 1977. 668p. 2v.

BASANTA, M.V.; DOURADO NETO, D.; GARCIA, A.G. Estimativa do volume máximo de calda para aplicação foliar de produtos químicos na cultura do milho. Scientia Agricola, v.57, n.2, p.283-288. Abr/Jun 2000.

BERNARDO, S. Manual de irrigação. 5.ed. Viçosa: UFV, 1989. 596p.

BODE, L.C. Spray application technology. In: WHORTER, C.G.M; GEBHARDT, M.R. Methods of applying herbicides. West Clark: WSSA, 1987. cap.6, p.85110 . 
BUCHLEITER, G., FARAHANI, H.J., BARTLETT, G. Evaluation of low-volume chemical application system. In: ANNUAL INTERNATIONAL ASAE MEETING, Sacramento, 2001. Abstracts. St. Joseph: ASAE, 2001. p. 535-542. (ASAE. Paper,. 012164)

CARVALHO, W.P.A. de. Estudo comparativo entre métodos de amostragens de gotas para determinação de faixa de deposição nas aplicações de produtos líquidos. Botucatu, 1995. 64p. Dissertação (Mestrado) - Faculdade de Ciências Agronômicas, Universidade Estadual Paulista "Júlio de Mesquita Filho".

CHALFANT, R.B.; YOUNG, J.R. Chemigation, or application of insecticide through overhead sprinkler systems, to manage insect pests infesting vegetable and agronomic crops. Journal of Economic Entomology, v.75, n.2, p.237-241. Apr 1982.

CHURCHILL, S.W. Friction factor equation spans all fluid-flow regimes. Journal of Chemical Engineering, v.84, n.24, p.91-92, Nov. 1977.

CIBA-GEIGY. Water sensitive paper for monitoring spray distribution. 3.ed. Basle: Ciba-Geigy, s.d. 15p.

CHRISTOFIDIS, D. Os recursos hídricos e a prática da irrigação no Brasil e no mundo. Item - Irrigação \& Tecnologia Moderna, n.49, p.8-13, 2001.

COELHO, R.D. Caracterização do sistema pivô central (LEPA) operando em condição de microrelevo condicionado. Piracicaba, 1996. 181p. Tese (Doutorado) - Escola de Engenharia de São Carlos, Universidade de São Paulo.

CUENCA, R.H. Irrigation system design: an engineering approach. Englewood Cliffs: Prentice Hall, 1989. 552p. 
CUPERY, E.W. Application accuracy. In: WHORTER, C.G.M; GEBHARDT, M.R. Methods of applying herbicides. West Clark: WSSA, 1987. cap.5, p.63-84.

DAN SPRINKLERS. Dan catalog. http://www.dansprink.com/dowload/dowload.html (02 Jan. 2001).

DOURADO NETO, D.; FANCELLI, A.L. Quimigação na cultura do feijão. In: FOLEGATTI, M.V. (Ed.). Fertirrigação. Guaíba: Agropecuária, 1999. p.393-432.

ESTADOS UNIDOS. Department of Agriculture. Soil Conservation Service. Trickle irrigation. Washington, 1979. 129p.

FANCELli, A.L.; DOURADO NETO, D. Produção de milho. Guaíba: Agropecuária, 2000. 360p.

FARIA, M.A.; VIEIRA, J. Irrigação por aspersão: sistemas mais usados no Brasil. Informe Agropecuário, v.12, n.139, p.27-39, jun. 1986.

FAVETTA, G.M. Estudo econômico do sistema de adução em equipamento de irrigação do tipo pivô central. Piracicaba, 1998. 110p. Tese (Doutorado) - Escola Superior de Agricultura “Luiz de Queiroz”, Universidade de São Paulo.

GARVEY, P.M. Liquid chemical spraying apparatus movable by a tower-type water irrigation system. 1980. US n 4277026. 7 Jul. 1981.

HOLLAND, J.M.; JEPSON, P.C.; JONES, E.C.; TURNER, O. A comparison of spinning disc atomizers and flat fan pressure nozzles in terms of pesticide deposition and biological efficacy within cereal crops. Crop Protection, v.16, n.2, p.179-185. 1997. 
INTERNATIONAL STANDART ORGANIZATION. Agricultural irrigation equipment - emitters - specification and test methods; ISO 9260:1991 (E). Genève, 1991. 7p.

JOHNSON, AW. ; YOUNG, J.R. THREADGILL, E.D.; DOWLER, C.C.; SUMMER, D.R. Chemigation for crop production management. Plant Disease, v.70, n.11, p.11-15, Nov. 1986.

KELLER, J. Sprinkler irrigation. Logan: Utah State University, 1984. 621p.

KELLER, J.; BLIESNER, R.D. Sprinkle and trickle irrigation. New York: AVI, 1990. $652 \mathrm{p}$.

LARSEN, R. Piggyback system turns pivot into chemical applicator. Irrigation Age, v.15, n.3, p. 8-9, Nov./Dec. 1980.

MÁQUINAS AGRÍCOLAS JACTO S.A.. Tecnologia de aplicação de defensivos agrícolas: calibração de pulverizadores. Indaiatuba, s.d., 36p.

MATTHEWS, G.A. Pesticide applications methods. 2.ed. Singapore: Longman, 1992. $405 \mathrm{p}$.

MATUO, T. Técnicas de aplicação de defensivos agrícolas. Jaboticabal: FUNEP, 1990. 139p.

MELO PORTO, R. Hidráulica básica. 1.ed. São Carlos: USP, EESC, 1998. 540p.

NORDBO, E. Effects of nozzle size, travel speed and air assistance on deposition on artificial vertical and horizontal targets in laboratory experiments. Crop Protection, v.11, p.272-278. Jun. 1992. 
OZEKI, Y.; KUNZ, R.P. Manual de aplicação aérea. São Paulo: CIBA AGRO, s.d. $46 \mathrm{p}$.

PARTICLE MEASURING SYSTEMS INC. Instruments for real - time characterization of atmospheric particles sampled in - situ. Boulard, s.d. 4p.

PEREIRA, A.S. Desenvolvimento de um protótipo aplicador de produtos químicos para um sistema de irrigação pivô central. Piracicaba, 2001. 64p. Tese (Doutorado) Escola Superior de Agricultura “Luiz de Queiroz”, Universidade de São Paulo.

PIVOT BARRA INDÚSTRIA E COMÉRCIO LTDA. Distribuidor de fértidefensivos agrícolas. Goiânia, s.d. 1v.

PIZARRO CABELLO, F. Riegos localizados de alta frecuencia. Madrid: MundiPrensa, 1987. 461p.

RAMOS, H.H. Tecnologia de aplicação de produtos fitossanitários. Cultivar Máquinas, v.1, n.1, jan/fev. 2001.

SILVEIRA, R.C.M.; HILLS, D.J.; YATES, W.E. Inseticide oil distribution pattern from a linear move spray head. Transactions of the ASAE, v.30, n.2, p.438-441, Mar/Apr. 1987.

SOLOMON, K.H. Yield related interpretations of uniformity measures. Irrigation Science, v.5, n.3, p.161-172, 1984.

SPRAY SYSTEMS CO. Produtos de pulverização para agricultura. Weathon, 1999. 104p. (Catálogo 46M-BR/P) 
STONE, K.C.; STANSELL, J.R.; YOUNG; J.R. Insecticide distribution through an irrigated corn canopy. Transactions of the ASAE, v.37, n.1, p.135-138, Jan./Feb. 1994.

SUMMER, H.R., GARVEY, P.M., HEERMANN, D.F., CHANDLER, L.D. Center pivot irrigation attached sprayer. Applied Engineering in Agriculture, v.13, n.3, p.323-327, May 1997.

THREADGILL, E.D. Chemigation via sprinkler irrigation: current status and future development. Applied Engineering in Agriculture, v.1, n.1, p.16-23, Feb. 1985.

TUCK, C.R.; BUTLER, M.C.; MILLER, P.C.H. Techniques for measurement of droplet size and velocity distributions in agricultural sprays. Crop Protection, v.16, n.7, p.619-628, June 1997.

VALLEY MAGAZINE. Accu-pulse precision applicator is a leap forward in the field. Valley: Valmont Irrigation, 2001. 22p.

VIEIRA, R.F. Introdução à quimigação. In: COSTA, E.F.; VIEIRA, R.F.; VIANA, P.A. Aplicação de produtos químicos e biológicos via água de irrigação. Brasília: EMBRAPA, SPI, 1994. cap.1, p.13-40.

VILELA, L.A.A. Irrigação por autopropelido e pivô central. Lavras: FAEPE, 1999. $82 \mathrm{p}$.

WEISS, N.A.; HASSET, M. Introductory statistics. Ontario : Adisson-Wesley, 1982. $651 \mathrm{p}$.

YOUNG J.R.; KEISLING, T.C.; STANSELL. Insecticide application with sprinkler irrigation. Transactions of the ASAE, v. 24, n.1, p.120-123, Jan./Feb. 1981. 
APÊNDICES 


\section{APÊNDICE 1}

\section{Especificações técnicas do equipamento de irrigação pivô central instalado na área} experimental da Fazenda Areão reservada ao Departamento de Engenharia Rural da ESALQ/USP, Piracicaba, SP.

\section{Pivô central}

Marca

Modelo

Número de lances (vãos)

Comprimento de cada lance (vão)

Comprimento até a última torre

Comprimento da tubulação em balanço

Comprimento total da tubulação

Raio efetivo da área irrigada

Área irrigada

Velocidade máxima de deslocamento

Tempo mínimo de revolução

Altura mínima livre em terreno plano

Precipitação mínima

Precipitação equivalente em $24 \mathrm{~h}$

Vazão total do sistema

Diferença de nível da água ao centro do pivô

2. Emissores

Marca

Modelo

Pressão de serviço

3. Válvula reguladora de pressão

Marca

Modelo

4. Canhão final

Marca

Modelo

Vazão

Bocal

Alcance

5. Adutora

Diâmetro

Extensão

6. Conjunto motobomba

Marca

Modelo

Diâmetro do rotor

Rotação

Potência do motor
Dantas irrigação S/A;

MD.400 BP MD 9.6/4 TVC

4

$38,9 \mathrm{~m}$

$155,6 \mathrm{~m}$

$12,5 \mathrm{~m}$

$168,1 \mathrm{~m}$

$193,1 \mathrm{~m}$

8,67 ha

$234,5 \mathrm{~m} / \mathrm{h}$

$5: 31 \mathrm{~h}$

$2,8 \mathrm{~m}$

$2,2 \mathrm{~mm}$

$9,6 \mathrm{~mm}$

$46,8 \mathrm{~m}^{3} / \mathrm{h}$

$58 \mathrm{~m}$

Senninger Irrigation

Super-.Spray

$250 \mathrm{kPa}$

Senninger Irrigation

LF, MF

Fabrimar

C1-SRL $24^{\circ}$

$13,4 \mathrm{~m}^{3} / \mathrm{h}$

$20 \mathrm{~mm}$

$25 \mathrm{~m}$

$125 \mathrm{~mm}$

$650 \mathrm{~m}$

KSB do Brasil S.A.

Meganorm Bloc 50-200

$205 \mathrm{~mm}$

$3500 \mathrm{rpm}$

29.420W (40cv) 


\section{APÊNDICE 2}

Esquema ilustrativo de algumas células da planilha utilizada para simulação das distribuições lineares preenchidas com valores de distâncias radiais (m) (a) e, respectivas intensidades de precipitação $(\mathrm{mm} / \mathrm{h})$ calculadas a partir do perfil de distribuição gerado para o bocal azul (b).

\begin{tabular}{|l|l|l|l|l|l|l|l|l|l|l|}
\hline 7,07 & 6,40 & 5,83 & 5,39 & 5,10 & 5,00 & 5,10 & 5,39 & 5,83 & 6,40 & 7,07 \\
\hline 6,40 & 5,66 & 5,00 & 4,47 & 4,12 & 4,00 & 4,12 & 4,47 & 5,00 & 5,66 & 6,40 \\
\hline 5,83 & 5,00 & 4,24 & 3,61 & 3,16 & 3,00 & 3,16 & 3,61 & 4,24 & 5,00 & 5,83 \\
\hline 5,39 & 4,47 & 3,61 & 2,83 & 2,24 & 2,00 & 2,24 & 2,83 & 3,61 & 4,47 & 5,39 \\
\hline 5,10 & 4,12 & 3,16 & 2,24 & 1,41 & 1,00 & 1,41 & 2,24 & 3,16 & 4,12 & 5,10 \\
\hline 5,00 & 4,00 & 3,00 & 2,00 & 1,00 & 0,00 & 1,00 & 2,00 & 3,00 & 4,00 & 5,00 \\
\hline 5,10 & 4,12 & 3,16 & 2,24 & 1,41 & 1,00 & 1,41 & 2,24 & 3,16 & 4,12 & 5,10 \\
\hline 5,39 & 4,47 & 3,61 & 2,83 & 2,24 & 2,00 & 2,24 & 2,83 & 3,61 & 4,47 & 5,39 \\
\hline 5,83 & 5,00 & 4,24 & 3,61 & 3,16 & 3,00 & 3,16 & 3,61 & 4,24 & 5,00 & 5,83 \\
\hline 6,40 & 5,66 & 5,00 & 4,47 & 4,12 & 4,00 & 4,12 & 4,47 & 5,00 & 5,66 & 6,40 \\
\hline 7,07 & 6,40 & 5,83 & 5,39 & 5,10 & 5,00 & 5,10 & 5,39 & 5,83 & 6,40 & 7,07 \\
\hline
\end{tabular}

(a)

\begin{tabular}{|l|l|l|l|l|l|l|l|l|l|l|}
\hline 50,88 & 53,24 & 55,14 & 56,54 & 57,39 & 57,67 & 57,39 & 56,54 & 55,14 & 53,24 & 50,88 \\
\hline 53,24 & 55,70 & 57,67 & 59,11 & 59,98 & 60,27 & 59,98 & 59,11 & 57,67 & 55,70 & 53,24 \\
\hline 55,14 & 57,67 & 59,69 & 61,14 & 62 & 62,28 & 62 & 61,14 & 59,69 & 57,67 & 55,14 \\
\hline 56,54 & 59,11 & 61,14 & 62,56 & 63,36 & 63,61 & 63,36 & 62,56 & 61,14 & 59,11 & 56,54 \\
\hline 57,39 & 59,98 & 62,00 & 63,36 & 64,03 & 64,17 & 64,03 & 63,36 & 62,00 & 59,98 & 57,39 \\
\hline 57,67 & 60,27 & 62,28 & 63,61 & 64,17 & 63,93 & 64,17 & 63,61 & 62,28 & 60,27 & 57,67 \\
\hline 57,39 & 59,88 & 62,00 & 63,36 & 64,03 & 64,17 & 64,03 & 63,36 & 62,00 & 59,88 & 57,39 \\
\hline 56,54 & 59,11 & 61,14 & 62,56 & 63,36 & 63,61 & 63,36 & 62,56 & 61,14 & 59,11 & 56,54 \\
\hline 55,14 & 57,67 & 59,69 & 61,14 & 62,00 & 62,28 & 62,00 & 61,14 & 59,69 & 57,67 & 55,14 \\
\hline 53,24 & 55,7 & 57,67 & 59,11 & 59,98 & 60,27 & 59,98 & 59,11 & 57,67 & 55,7 & 53,24 \\
\hline 50,88 & 53,24 & 55,14 & 56,54 & 57,39 & 57,67 & 57,39 & 56,54 & 55,14 & 53,24 & 50,88 \\
\hline
\end{tabular}

(b) 


\section{APÊNDICE 3}

\section{Fluxograma do programa SPPC}
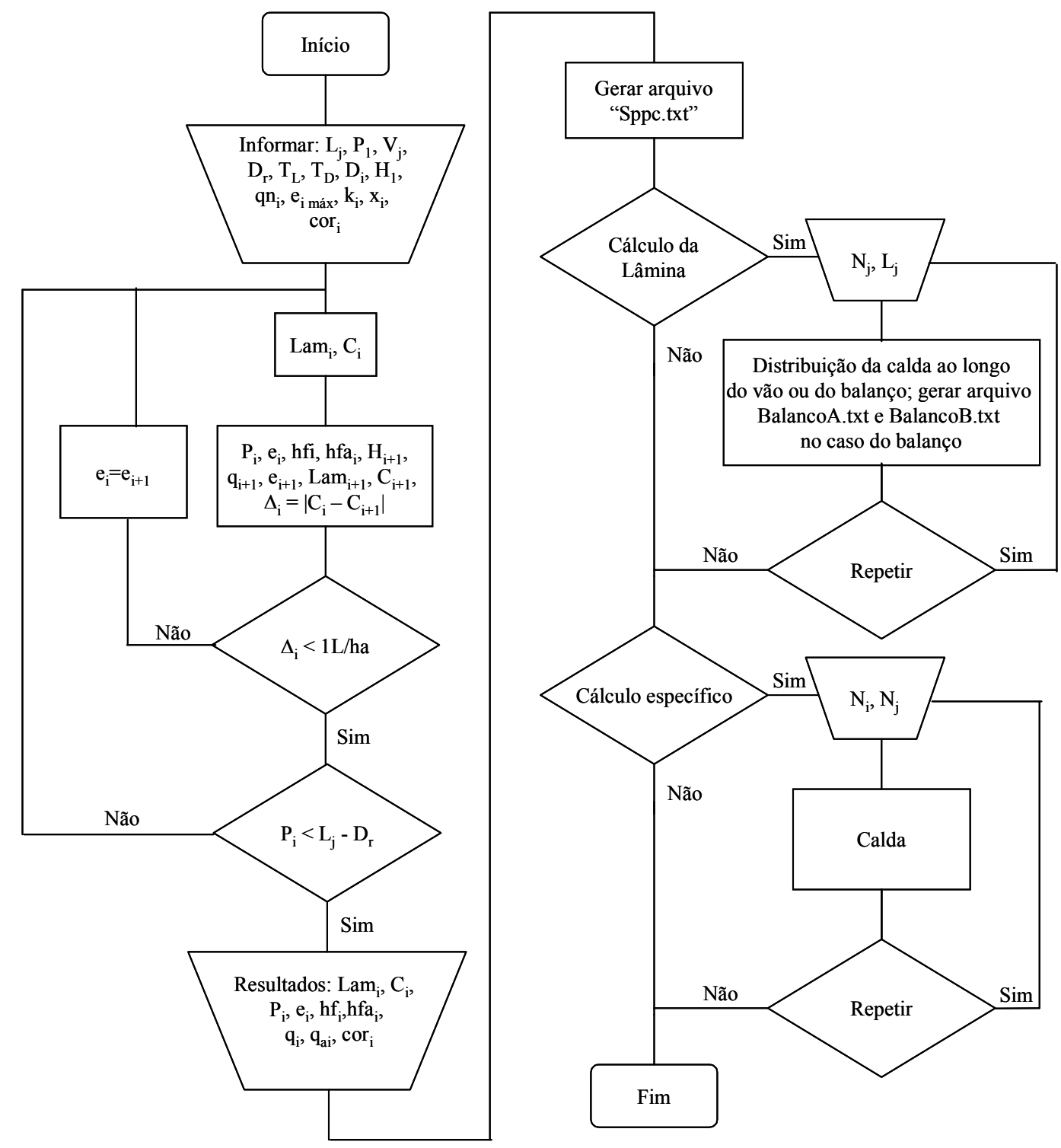

em que $L_{j}(\mathrm{~m})$ é o comprimento do vão; $\mathrm{P}_{1}(\mathrm{~m})$ a posição do primeiro emissor; $V j(\mathrm{~m} / \mathrm{h})$ a velocidade de deslocamento do sistema de propulsão da j-ésima torre; $D_{\mathrm{r}}(\mathrm{m})$ a distância entre o plano vertical que passa no centro geométrico das rodas e o último emissor; $\mathrm{T}_{\mathrm{L}}(\mathrm{s})$ o tempo de abertura da válvula solenóide; $\mathrm{T}_{\mathrm{D}}(\mathrm{s})$ o tempo de fechamento da válvula solenóide; $\mathrm{D}_{\mathrm{i}}(\mathrm{mm})$ diâmetro interno da barra de pulverização; $\mathrm{H}_{1}(\mathrm{kPa})$ a pressão de serviço do emissor mais distante da válvula solenóide (primeiro emissor); $\mathrm{qn}_{\mathrm{i}}(\mathrm{L} / \mathrm{h})$ a vazão do i-ésimo emissor operando sob pressão de $211 \mathrm{kPa} ; \mathrm{e}_{\mathrm{i} \text { máx }}(\mathrm{m})$ a largura máxima da faixa de deposição do 


\section{APÊNDICE 3}

\section{Fluxograma do programa SPPC}

i-ésimo emissor; $\mathrm{k}_{\mathrm{i}}\left(\mathrm{L} / \mathrm{h} \mathrm{kPa}^{-\mathrm{x}}\right)$ o coeficiente de ajuste da equação pressão-vazão do i-ésimo emissor; $\mathrm{x}_{\mathrm{i}}$ (adimensional) o expoente característico do i-ésimo emissor; cor $_{\mathrm{i}}$ a cor do bocal do i-ésimo emissor; Lam $_{\mathrm{i}}$ (mm) a lâmina a ser aplicada pelo sistema de pulverização; C (L/ha) a calda a ser aplicada pelo sistema de pulverização; $\mathrm{P}_{\mathrm{i}}(\mathrm{m})$ posicionamento do i-ésimo emissor ao longo do vão, a partir do lado oposto da alimentação da barra; $\mathrm{e}_{\mathrm{i}}(\mathrm{m})$ a largura da faixa de deposição do i-ésimo emissor; $\mathrm{hf}_{\mathrm{i}}(\mathrm{kPa})$ a perda de carga total entre o i-ésimo emissor e o subseqüente; $\mathrm{hfa}_{\mathrm{i}}(\mathrm{kPa})$ a perda de carga acumulada até o i-ésimo emissor; $H_{i}(\mathrm{kPa})$ a pressão de operação do i-ésimo emissor; $\mathrm{q}_{\mathrm{i}}(\mathrm{L} / \mathrm{h})$ a vazão do i- ésimo emissor; $\Delta_{\mathrm{i}}$ (L/ha) a diferença entre a calda aplicada pelo emissor que está sendo calculado e a calda a ser aplicada pelo sistema de pulverização; $q a_{i}(L / h)$ a vazão acumulada até o i-ésimo emissor; $\mathrm{N}_{\mathrm{j}}$ o número de ordem do vão e; $\mathrm{N}_{\mathrm{i}} \mathrm{o}$ número de ordem do emissor. 